University of Louisville

ThinkIR: The University of Louisville's Institutional Repository

Electronic Theses and Dissertations

$12-2011$

\title{
Three essays on the influence of formal institutions on entrepreneurship.
}

Michael David Crum

University of Louisville

Follow this and additional works at: https://ir.library.louisville.edu/etd

Part of the Entrepreneurial and Small Business Operations Commons

\section{Recommended Citation}

Crum, Michael David, "Three essays on the influence of formal institutions on entrepreneurship." (2011). Electronic Theses and Dissertations. Paper 294.

https://doi.org/10.18297/etd/294

This Doctoral Dissertation is brought to you for free and open access by ThinkIR: The University of Louisville's Institutional Repository. It has been accepted for inclusion in Electronic Theses and Dissertations by an authorized administrator of ThinkIR: The University of Louisville's Institutional Repository. This title appears here courtesy of the author, who has retained all other copyrights. For more information, please contact thinkir@louisville.edu. 


\title{
THREE ESSAYS ON THE INFLUENCE OF FORMAL INSTITUTIONS ON ENTREPRENEURSHIP
}

By

Michael David Crum

\author{
A Dissertation \\ Submitted to the Faculty of the \\ College of Business of the University of Louisville \\ in Partial Fulfillment of the Requirements \\ for the Degree of
}

Doctor of Philosophy

College of Business

University of Louisville

Louisville, Kentucky

December 2011 


\title{
THREE ESSAYS ON THE INFLUENCE OF FORMAL INSTITUTIONS ON ENTREPRENEURSHIP
}

\author{
By
}

Michael David Crum

A Dissertation Approved on

September 30, 2011

By the following Dissertation Committee:

\begin{tabular}{c}
\hline Dissertation Chair \\
\hline Bruce H. Kemelgor \\
\hline James O. Fiet \\
\hline Jill L. Adelson
\end{tabular}




\section{ACKNOWLEDGEMENTS}

I would like to thank my dissertation committee as well as the other faculty at the University of Louisville who advised and mentored me over the course of my Ph.D.

program. I would also like to thank the Kauffman Foundation for use of the Kauffman Firm Survey data in this dissertation. Finally, I would like to thank my parents, family members, and friends who put up with me over the long process of obtaining my Ph.D. 


\section{ABSTRACT \\ THREE ESSAYS ON THE INFLUENCE OF FORMAL INSTITUTIONS ON ENTREPRENEURSHIP \\ Michael David Crum \\ September 30, 2011}

This dissertation is composed of three essays in which I examine the influence of formal institutions on entrepreneurs and new firms. In the first essay, "The Influence of Institutions on the Likelihood of Self-Employment: A Multilevel Analysis," I examine how institutions at the country-level are related to the likelihood that individuals in those country are self-employed. Country-level measures of formal institutions are paired with individual-level data on self-employment from the Global Entrepreneurship Monitor (Reynolds et al., 2005). Using the Fraser Institute's Economic Freedom of the World index and the Heritage Foundation's Index of Economic Freedom separately as measures of institutions, I find that sound money in a country is positively associated with individual self-employment with both indices. Property rights and trade freedom are positively related to self-employed using the Economic Freedom of the World index.

In the second essay, "Labor Market Institutions and New Firm Employment Growth,"' I examine how state-level labor market characteristics such as minimum wages, union densities, and unemployment insurance premiums influence employment growth in new firms. I use firm-level data from the Kauffman Firm Survey (DesRoches, Robb, \& 
Mulcahy, 2009), which contains data from several thousand new firms for years 20042008. Minimum wages, union densities, and unemployment insurance structure do not predict the level of employment in new firms in the manner hypothesized.

In the third essay, "The Impact of Taxes and Regulations on New Firm Births and Deaths in State Border Counties," I examine how state-level measures of government size, taxation burdens, unionization levels, and minimum wages influence the birth and death rates of firms in counties located on state borders. Tabulations containing data on establishment births and deaths by U.S. County (Plummer \& Headd, 2008) were merged with measures of government size, taxation burdens, union densities, and minimum wages. I find a negative relationship between the overall tax burden and the birth rate of new firms. However, unionization, minimum wages and government size are not related to the birih and death rates of firms in the manner hypothesized. 


\section{TABLE OF CONTENTS}

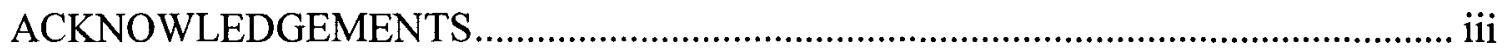

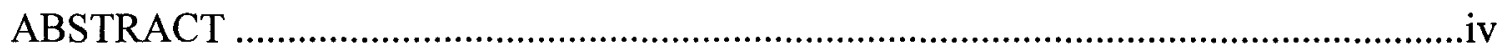

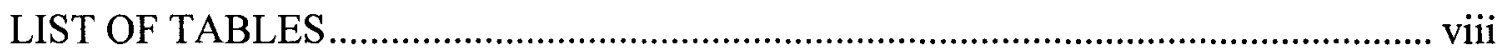

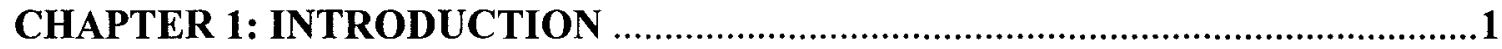

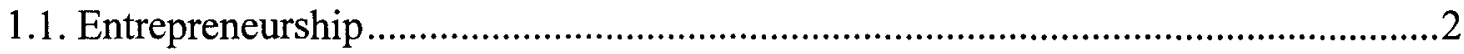

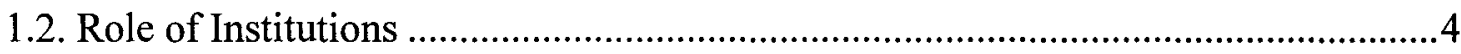

1.3. Summary of the Three Essays ............................................................................. 10

\section{CHAPTER 2: THE INFLUENCE OF INSTITUTIONS ON THE LIKELIHOOD} OF SELF-EMPLOYMENT: A MULTILEVEL ANALYSIS …….........................14

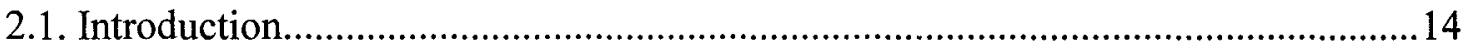

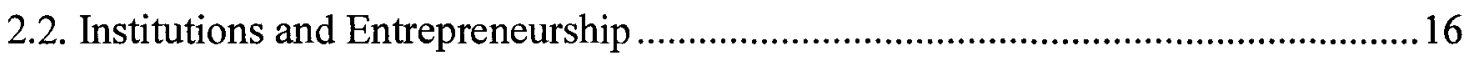

2.3. Model of Entrepreneurial Activity ....................................................................18

2.4. Institutions and the Likelihood of Self-Employment ..............................................22

2.5. Institutions and Self-Employment: Moderating Effects ..........................................38

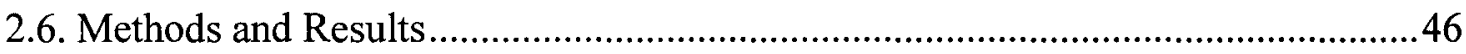

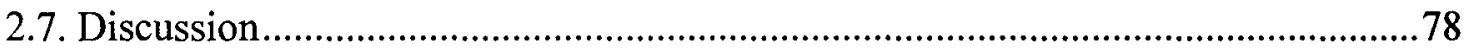

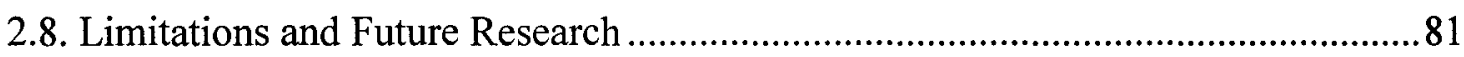

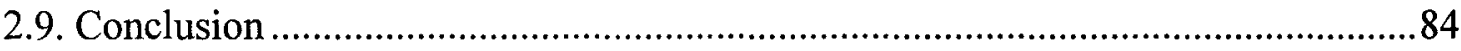

CHAPTER 3: LABOR MARKET INSTITUTIONS AND NEW FIRM

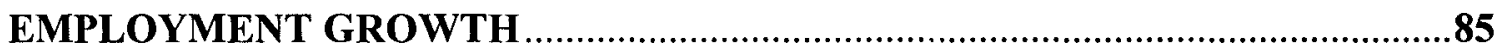

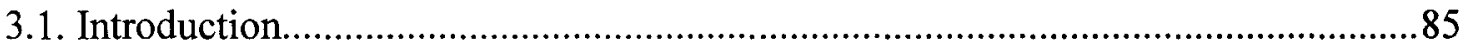

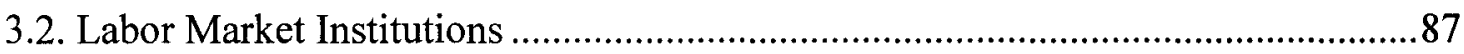

3.3. Labor Market Institutions and New Firms …………..............................................89

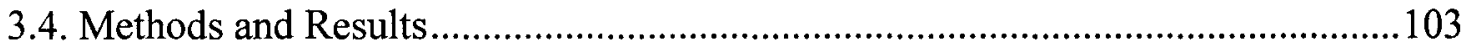




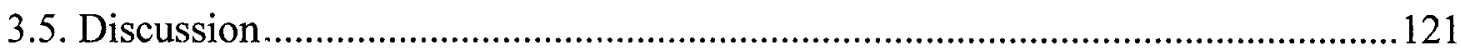

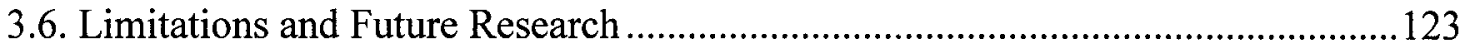

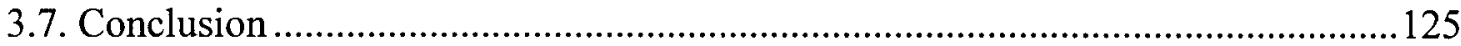

CHAPTER 4: THE IMPACT OF TAXES AND REGULATIONS ON NEW FIRM BIRTHS AND DEATHS IN STATE BORDER COUNTIES ...............................126

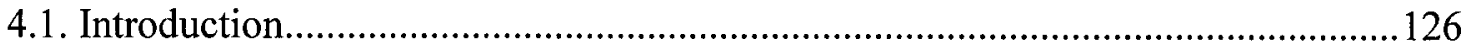

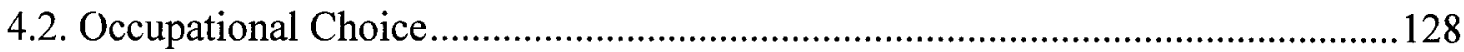

4.3. Taxes, Regulations and Firm Births and Deaths ............................................131

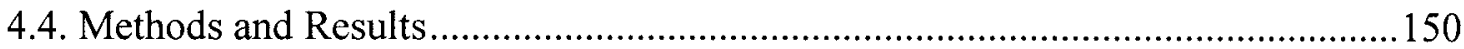

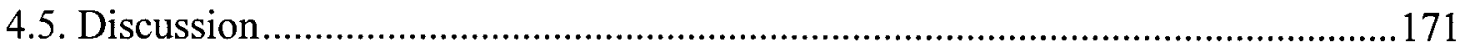

4.6. Limitations and Future Research ..................................................................... 173

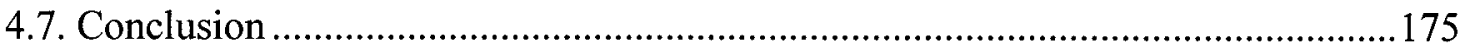

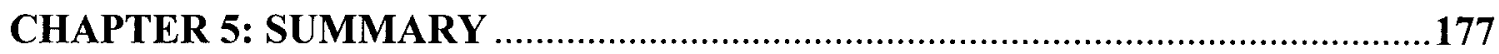

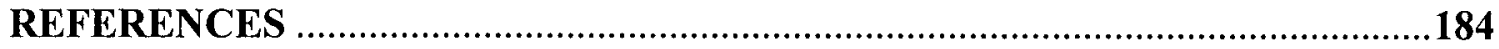

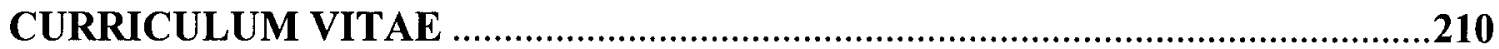




\section{LIST OF TABLES}

2.1. Economic Freedom of the World Index Components..........................................................5

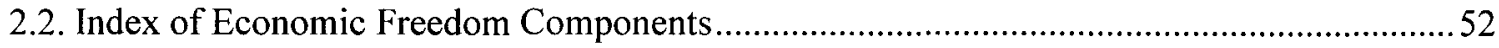

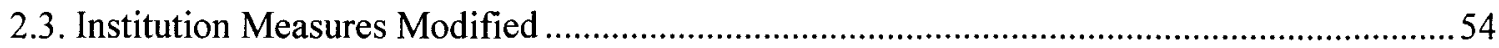

2.4. Correlation Between EFW Components and Modified IEF Components.............................. 54

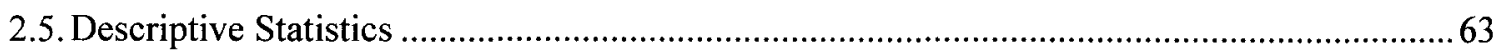

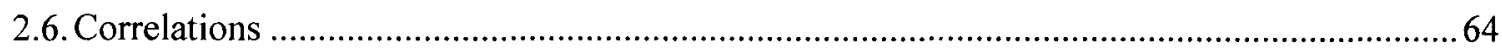

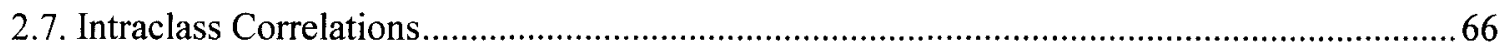

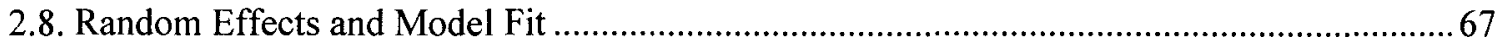

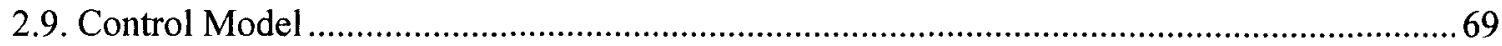

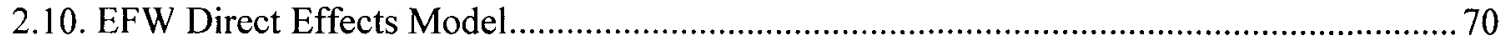

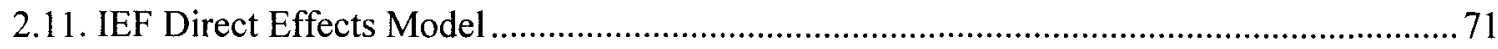

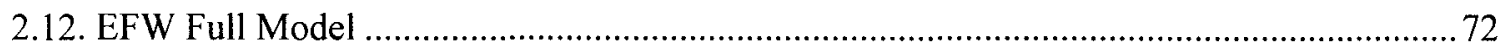

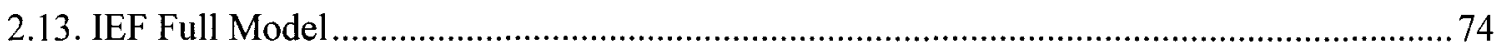

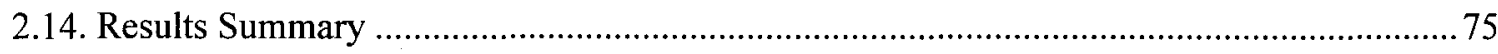

2.15. Post Hoc Test- Multiple Regulation Measures .............................................................. 78

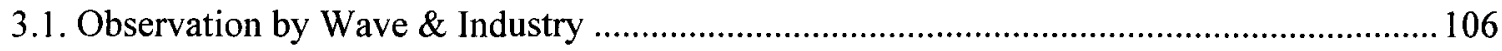

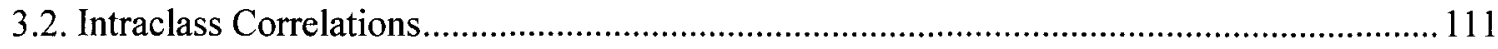

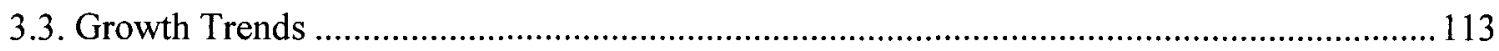

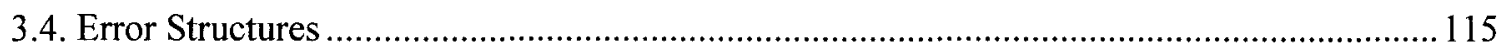

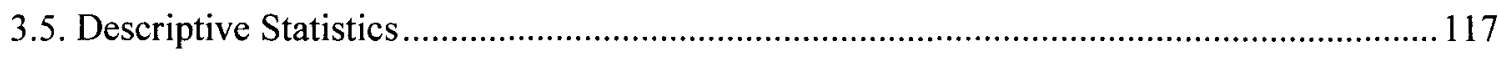

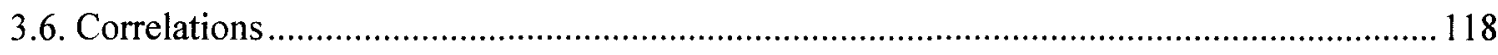

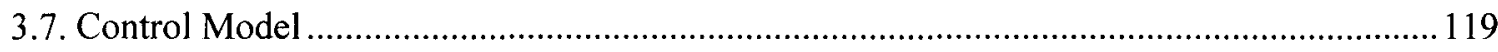

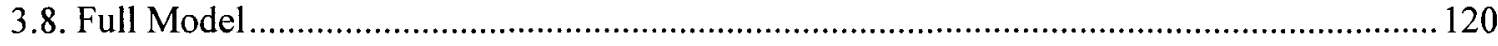

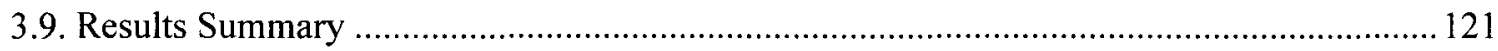

4.1. Studies on Taxes and Firm Entry/Entrepreneurship ................................................... 136 


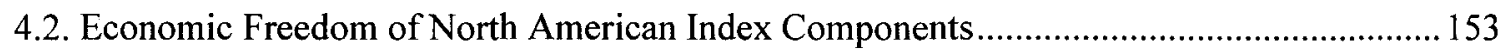

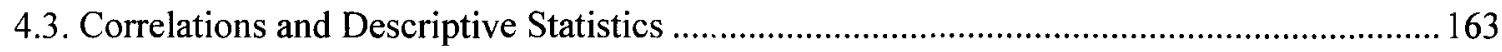

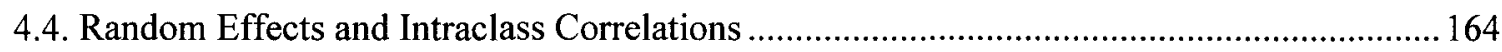

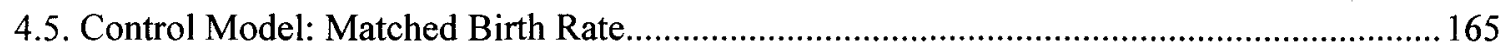

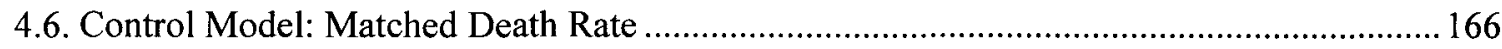

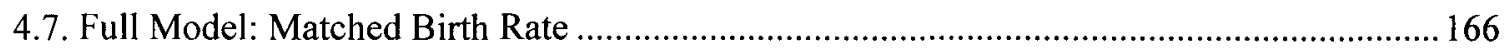

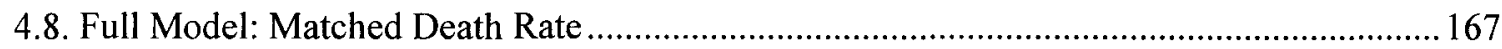

4.9. Interaction Model: Sector Firm Birth Rate .................................................................. 170

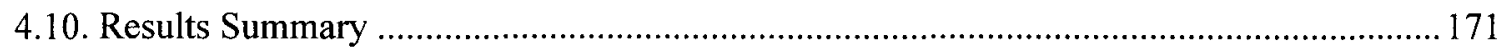




\section{CHAPTER 1: INTRODUCTION}

The decision to become an entrepreneur, as well as one's ultimate success at it, is the result of both individual characteristics as well as the environment in which entrepreneurs find themselves (Shane, 2003). In addition to individual differences, environmental factors are likely to influence the behavior of entrepreneurs as well. As noted by Baumol (1990), the reward structure in an economy may not only influence the level of entrepreneurship, but it is likely to influence the types of entrepreneurship that manifests itself. When the "rules of the game" incentivize certain activities and discourages others, the behavior of economic actors is bound to be influenced by them (North, 1987). In this dissertation, I examine how formal institutions - the rules of the game developed through constitutions, statutory law, and legal precedent (Williamson, 2000) - influence entry into entrepreneurship as well as the behavior of existing entrepreneurs.

In this dissertation I develop three essays that discuss and test the influence of formal institutions on the behavior of entrepreneurs. The first essay, "The Influence of Institutions on the Likelihood of Self-Employment: A Multilevel Analysis," examines the relationship between institutions and self-employment. Country-level institution measures include taxation levels, the strength of property rights, soundness of money, trade freedom, and the level of business regulation. I also examine how individual 
characteristics interact with country-level variables to determine the likelihood that individuals will be self-employed. In the second essay, "Labor Market Institutions and New Firm Employment Growth," I examine how state-level labor market factors such as minimum wages, union density, and unemployment insurance premiums influence employment growth in new firms. Finally, in the third essay, "The Impact of Taxes and Regulations on New Firm Births and Deaths in State Border Counties," I examine how state-level measures of government size, tax burdens, unionization levels, and minimum wages influence the birth and death rates of new firms in counties located on state borders. Differences in birth rates between manufacturing and service firms are examined as well.

The rest of this chapter proceeds as follows. First, entrepreneurship is briefly discussed. Secondly, the literature on institutions and their impact on growth and entrepreneurship are examined. Finally, this chapter concludes with a brief summary of the three essays of this dissertation.

\subsection{ENTREPRENEURSHIP}

The term entrepreneurship is associated with multiple definitions, including the creation of a new firm (Gartner, 1988), the discovery, evaluation, and exploitation of opportunities to create future goods and services (Shane \& Venkataraman, 2000), innovation (Schumpeter, 1942), self-employment and small business management (Davidsson, 2004). Not only has entrepreneurship been defined in various ways, it also has been measured in many ways, such as self-employment rates, nascent entrepreneurship rates, and new firm births (Davidsson, 2004). In this dissertation, 
several measures of entrepreneurship will be used, such as self-employment and new firm entry (creation of a new firm).

The level of entrepreneurship varies substantially among various legal jurisdictions, whether measured by self-employment, new firm startups, or innovation. Countries tend to have varying levels of self-employment (Blanchflower, 2000; Noorderhaven, Thurik, Wennekers, \& Van Stel, 2004), nascent entrepreneurship (Arenius \& Minniti, 2005; Wennekers, van Stel, Thurik, \& Reynolds, 2005) and innovation (Shane, 1993). Furthermore, states and provinces within a country vary in the level of entrepreneurship that they have (Campbell \& Rogers, 2007; Sobel, 2008). A number of possible explanations may exist for these differences, including varying institutions (formal and informal), wealth, unemployment levels, and human capital differences among regions.

Determining what factors influence the level and type of entrepreneurship is important for several reasons. Entrepreneurship may be personally fulfilling because it is challenging and allows a high degree of personal freedom. Engaging in entrepreneurship is something that individuals often prefer to do in comparison to working for a wage (Blanchflower, Oswald, \& Stutzer, 2001; Gohmann, in press; Kolvereid, 1996). However, certain environmental factors may limit an individual's ability to become an entrepreneur, even when they have the desire to become an entrepreneur and profitable opportunities exist. Entrepreneurship is also important for the wider economy due to the positive externalities that it generates. Entrepreneurship leads to the commercialization of new goods and services (Kirchhoff, 1994; Shane \& Venkataraman, 2000) and 
entrepreneurs have brought many innovations to market (Kenney, 1986). Furthermore, evidence suggests that entrepreneurship is associated with economic growth (Thurik \& Wennekers, 2004) as well as job creation (Fölster, 2000; Kirchhoff, 1994).

\subsection{THE ROLE OF INSTITUTIONS}

The term "institution" is a broad term that has been defined in various ways in the social sciences. For this dissertation, I use the concept of "institutions" that has been found in the new institutional economics literature. Thus, institutions set the "rules of the game" in an economy; determining incentives, reducing uncertainty, and influencing transaction costs in an economy (North, 1987). Pejovich (1998) similarly states that institutions are "the legal, administrative and customary arrangements for repeated human interactions" (p. 23). Institutions constrain human action and influence how humans interact with one another (North, 1990).

Institutions can be both informal and formal (North, 1990). Informal institutions include norms, social conventions, codes of behavior, and customs. These originate from the experience, routines, culture, and religious beliefs of a society (Klein, 2000; Pejovich, 1998; Williamson, 2000). Thus, informal institutions may last a very long time, perhaps centuries (Williamson, 2000) and may influence a number of economic outcomes (North, 1990). For example, in many societies, dishonesty is considered an inappropriate form of

behavior (Knowles \& Weatherston, 2006; North, 1990). Individuals who are dishonest will face social sanction which is likely to discourage dishonest behavior, decreasing transaction cost in the society (Knowles \& Weatherston, 2006). Conversely, formal institutions are the rules that originate from constitutions, statutory law and legal 
precedent (North, 1990; Williamson, 2000). Formal institutions typically change with more regularity, although some may last substantial periods of time as well (Williamson, 2000). Informal and formal institutions are closely and causally related to one another. Norms, customs, and traditions have an impact on formal institutions, by such mechanisms as the laws and constitutions that a country adopts. Furthermore, the laws of a country may influence the norms, customs and codes of behavior in a society. For example, in addition to affecting changes in social norms leading to increased tobacco taxes and regulations in the United States, it is likely that increasing regulations (changes in formal institutions) have also affected the norms regarding smoking (Hamilton, Biener, \& Brennan, 2008; Nyborg \& Rege, 2003).

North (1990) uses the example of a sporting event to further clarify what is meant by institutions and to differentiate institutions from organizations. Take the example of a basketball game that occurs between two opposing teams. The teams are an organization; they do not set the rules of the game, but they are obligated (or at least have a strong incentive) to abide by them, just like individuals and organizations within an economy. Formal institutions are the rules of the game actually written down in the rulebook that are enforced by the referees. These would include rules against excessive physical contact with other players (fouling), rules that prevent players from blocking shots that are on a downward trajectory (goaltending), and rules determining how many points a basket is worth. The rules against goaltending clearly give players a substantial incentive not to engage in goaltending because the punishment for doing so is to count the basket as if it were actually made. Furthermore, in basketball, there are many informal 
institutions that influence player behavior as well. For example, sportsmanship is a social convention among basketball players. It is generally considered unsportsmanlike for basketball players not to shake the hands of other players at the end of a game. Although a player breaking this "rule" is not breaking any official basketball rules and will face no punishment from referees, they likely will face disgust by fans and other players. Both the formal and informal institutions in this example reduce the uncertainty that players and teams face because they are aware of what behaviors are acceptable as well as the sanction they will face for behaving in an unacceptable manner. They also know what punishment players of the opposing team will face if they violate these rules, and thus have some expectations about what the opposing team is likely to do (the other team is likely not to engage in goaltending very often, for example). The institutions also determine the incentives in the basketball game. Because basketball rules (formal institution) state that a shot taken behind the three-point line is worth three points instead of two, players have more of an incentive to take these shots than they would if they were simply worth two points.

Institutions, both formal and informal, have been used to explain economic outcomes, such as economic growth. However, many theories developed to explain economic growth do not explicitly consider the institutions (Gwartney, Holcombe, \& Lawson, 2004). Solow's (1957) neoclassical growth model predicted that economic output was a function of capital, labor, and the effectiveness of labor. Therefore, in Solow's model, economic growth was mainly due to the effectiveness of labor ${ }^{1}$ (Romer,

\footnotetext{
${ }^{1}$ Although variation in capital could increase economic growth according to the Solow model, long-term growth would be due to changes in the effectiveness of labor.
} 
1996). Although economic thinking regarding economic growth has since evolved, the convergence prediction of Solow's (1957) model has received some empirical support (Barro \& Xavier, 1992). That is, economies with low level of per capita income tend to grow more quickly over time and tend to catch up with those with higher initial levels of per capita income. Later, theories of endogenous growth began to emerge that focused on the effectiveness of labor factor that explained much of the variance in economic growth in Solow's (1957) model (Romer, 1994). Additionally, researchers (Gallup, Sachs, \& Mellinger, 1999) have argued for many other predictors of economic growth, including climate and geography. Climate and geography have an effect on transportation cost, the productively of agriculture, and the level of disease. Natural resources are thought to have an influence on economic growth, with substantial natural resource wealth, oddly enough, being associated with low economic growth (Sachs \& Warner, 2001). This is thought to be due to "Dutch Disease" which occurs when an extreme increase in a nation's wealth due to an increase in the value of natural resources causes the currency to strengthen relative to other currencies. This makes products manufactured in the country more expensive on the world market, leading to fewer exports and less investment in manufacturing (Corey, 2009; Stevens, 2003).

Institutional economics does not view economic growth as an inevitable outcome. Instead, institutions first must be adopted in an economy that reduces the cost of transacting, encourages capital and labor to be put towards productive uses, and allows the sharing and transfer of risk (Klein, 2000). Like with the basketball example, the rules in a society are likely to determine how the game is played, as well as the outcome. In 
the 1986-1987 basketball season, the NCAA adopted the three-point line (Bradley, 2009). This rule change allowed more total points to be scored in a game, gave an advantage to teams that had effective long-range shooters, and gave teams a greater chance to come back and win the game after being substantially behind. Likewise, differences in the "rules of the game" between countries will lead to different behavior by individuals and organizations within those countries, which will ultimately lead to differences in economic outcomes- such as growth, unemployment levels, and the distribution of income. While some institutions may lead to stagnation and high unemployment, those that encourage specialization of labor and efficient use of capital are likely to lead to high levels of employment and substantial economic growth (North, 1990). Subsequent research has produced a plethora of findings supporting the idea that different types of institutions are associated with different levels of wealth and growth in economies (Barro, 1996; Dawson, 2003).

One challenge in using institutions to predict economic growth is determining which institutions are likely to influence economic growth, as well as how to measure them. While the "quality" of institutions has been conceptualized and measured in many different ways, one common measure of institutions has been the level of economic freedom in an economy (Gwartney \& Lawson, 2003). Economic freedom refers to the "freedom to choose which goods or services to buy, where to invest, and with whom to trade, and to set a mutually acceptable exchange price" (Johnson \& Lenartowicz, 1998: p. 337). Economic freedom is said to exist when property rights are protected; governments are small, and taxes are low; currency is sound; and few government restrictions are 
placed on an individual's ability to contract with other parties (Gwartney et al., 2004). Empirical research has generally supported the hypothesis that countries with high levels of economic freedom have higher growth rates than those with low levels of economic freedom (De Haan \& Sturm, 2000; Dollar, 1992; Easton \& Walker, 1997; Farr, Lord, \& Wolfenbarger, 1998; Gwartney, Lawson, \& Holcombe, 1999; Heckelman, 2000). The specific effect of property rights on economic growth have been discussed and examined as well (Gwartney et al., 2004; Leblang, 1996; Torstensson, 1994). Property rights refer to "the individual's ability, in expected terms, to consume the good (or the services of the asset) directly or to consume it indirectly through exchange" (Barzel, 1997: p. 3). When property rights are protected by governments through legal protections, individual actors in the economy can make long-term, capital investments without worrying about whether their property will be expropriated by the government or other parties. Because contracts will be enforced by the courts, transaction costs are low (Pejovich, 1998). Thus, strong property rights reduce uncertainty, and thus give economic actors more incentive to make long-term investments (Besley, 1995).

While institutions have been associated with economic growth, institutions merely set the "rules of the game" in an economy; economic players must act in order for economic growth to occur. Thus, institutions are likely to influence other drivers of economic growth, such as entrepreneurship. Certain institutions may influence the number of individuals who become entrepreneurs (McMullen, Bagby, \& Palich, 2008; Ovaska \& Sobel, 2005), the type of entrepreneurship in which individuals engage 
(Baumol, 1990; Sobel, 2008), as well as the ultimate success of their business ventures (Sobel, Clark, \& Lee, 2007).

In this dissertation, I build on this research by examining how institutions influence the behavior of entrepreneurs in three different contexts.

\subsection{SUMMARY OF THE THREE ESSAYS}

Essay \#1: The Influence of Institutions on the Likelihood of Self-Employment: A

\section{Multilevel Analysis}

Past research has examined the relationship between institutions and entrepreneurship (Aidis, Estrin, \& Mickiewicz, 2009; McMullen et al., 2008; Sobel, 2008). Although some relationships have been found between measures of institutions and entrepreneurship, there has been little attempt to examine how institutions interact with individual characteristics to influence the likelihood that an individual will be selfemployed. Small government size, property rights protection, sound money, freedom to trade, and business freedom are hypothesized to increase the probability that an individual in that country is engaged in self-employment. Also, an individual's education level and regulatory focus are hypothesized to interact with institutional factors to determine the likelihood that an individual will be engaged in self-employment.

In this essay, the relationship between institutions and entrepreneurship is tested using two sets of measures of institutions: (1) The Economic Freedom of the World index (Gwartney, Lawson, Sobel, \& Leeson, 2007) and (2) the Index of Economic Freedom (Heritage Foundation, 2005). The 10 components from the Index of Economic Freedom 
are modified so that they are conceptually equivalent to the five components from the Economic Freedom of the World index. Therefore, five different measures of institutions are used from the two different indices: size of government, property rights, sound money, trade freedom, and business freedom. This allows the robustness of these relationships to be examined. Individual-level data on self-employment comes from the Global Entrepreneurship Monitor (Reynolds et al., 2005). Multi-level modeling is performed using the lmer and glmmPQL packages in $\mathrm{R}$ to estimate how these institutional variables influence the probability that an individual is engaged in selfemployment. Some support is found for a positive relationship between trade freedom, property rights, and sound money in the country in which an individual resides and the likelihood that they are engaged in self-employment. Government size/taxation levels and the level of business regulations do not predict engagement in self-employment in the hypothesized manner. This essay is presented in Chapter 2.

\section{Essay \#2: Labor Market Institutions and New Firm Employment Growth}

Labor market institutions include the taxes on labor, minimum wages, employment regulations, social security taxes and benefits, and laws governing unionization in an economy (Nickell 1998). Labor market institutions develop over time, often as a result of various social movements and economic shocks (Thelen, 2004) and vary widely across countries and sometimes even among regions or states within a country. Because these institutions set the rules for both employees and employers, they ultimately influence the cost of labor and affect hiring, firing, and other employment decisions within the firm. In this essay, I examine how minimum wages, unemployment 
insurance premiums, and unionization levels impact employment growth in new firms. I hypothesized that low minimum wages and low unemployment insurance premiums will increase hiring and lead to higher levels of employment among new firms. Conversely, high levels of unionization are predicted to lead to increased firm employment levels.

For this essay, I obtain firm-level data from Kauffman Firm Survey (DesRoches, Robb, \& Mulcahy, 2009), which contains data on several thousand new firms followed longitudinally across five waves which were collected for years 2004-2008. I match these data with state-level data minimum wage, unemployment tax, and unionization data. Multilevel modeling using the SAS Glimmix procedure is then used to see how the labor market factors in the state in which the firm operates predicts the firm employment level over time. State union density is found to have a marginal negative effect on firm employee growth. I found no relationship between both minimum wages and the unemployment insurance structure and employee growth in new firms. This essay is presented in Chapter 3.

\section{Essay \#3: The Impact of Taxes and Regulations on New Firm Births and Deaths in}

\section{State Border Counties.}

This essay answers the following question: How do state-level taxes and regulations influence the birth and death rates of firms? I hypothesize that small government size, low tax burden, and low minimum wages will be associated with high levels of firm births, especially among manufacturing firms. In addition, I hypothesize that small government size, low tax burden, and low minimum wages will be associated with a high level of firm deaths as well. 
Data on firm births and deaths by industry are obtained from a custom tabulation from the U.S. Census Bureau's Company Division. Known as the EBD (establishment births and deaths), these tabulations contains data on establishment births and deaths for each county in the United States from 1989-2005 (Plummer \& Headd, 2008). More specifically, for each county in the United States, these tabulations contain the total single-unit, multi-unit, and total establishment births and deaths and the firm's five-digit North American Industry Classification System (NAICS) code. These data are merged with measures of government size, tax burdens, union densities, and minimum wages from the Economic Freedom of North America index (Karabegovic, McMahon, \& Mitchell, 2005). Furthermore, the overall county tax burden data are obtained from the U.S. Census of Governments. In the analysis, only counties on state borders are examined, and these counties are matched with other counties that are located on the other side of the state border. This allows for the control for a number of unobservable factors (Holcombe \& Lacombe, 2004a). I found support for a negative relationship between overall tax burden and the birth rate of new firms. However, unionization, minimum wages and government size did not influence the birth and death rates of firms in the manner hypothesized. 


\section{CHAPTER 2: THE INFLUENCE OF INSTITUTIONS ON THE LIKELIHOOD OF SELF-EMPLOYMENT: A MULTILEVEL ANALYSIS}

\subsection{INTRODUCTION}

Formal institutions are significant predictors of economic growth in an economy (Barro, 1996; De Haan \& Sturm, 2000; Rodrik, Subramanian, \& Trebbi, 2004). In addition, scholars have argued that a relationship exists between institutions and the level and type of entrepreneurship that manifests itself (Baumol, 1990; Sobel, 2008). Recently, empirical work has started to examine the influence institutions have on entrepreneurship. For example, small government size is positively related to sole proprietor growth rates (Kreft \& Sobel, 2005) and self-employment rates (Nyström, 2008). Furthermore, a heavily regulated business environment is associated with a decrease in new firm entry (Klapper, Laeven, \& Rajan, 2006; van Stel, Storey, \& Thurik, 2007). The level of economic freedom, or the extent to which governments allow free exchange and protect property rights (Gwartney et al., 2007), is associated with increased levels of entrepreneurship, indicated by increases in variables such as venture capital availability, innovation (Sobel, 2008), and net new business formation (Campbell \& Rogers, 2007). Likewise, economic freedom is negatively related to unproductive entrepreneurial activities such as lobbying (Sobel, 2008). 
Although empirical work has begun to examine the relationship between institutions and entrepreneurship, many unanswered questions remain. Most research examining the relationship between institutions and entrepreneurship uses aggregated measures of entrepreneurship, such as the rate of self-employment or innovation in a country or state (Bjornskov \& Foss, 2008; McMullen et al., 2008; Sobel, 2008; Sobel et al., 2007). The disadvantage to using an aggregated analysis is that it does not allow for the control of individual characteristics and for the testing of cross-level interactions (Luke, 2004; Tabachnick \& Fidell, 2006). Thus, we do not know to what degree individual characteristics interact with the institutional environment to influence the likelihood that an individual is engaged in entrepreneurship. Another concern is that many studies use different samples and different yet overlapping measures of institutions. For example, whereas small government size relates positively to entrepreneurial activity in several studies (Bjornskov \& Foss, 2008; Nyström, 2008), a recent study using a different measure of government size found it to be non-significant (McMullen et al., 2008). Although many measures of institutions are available, economic freedom indices are perhaps the most commonly used. Two major economic freedom indices exist for countries (1) the Economic Freedom of the World index, published by the Fraser institute (Gwartney et al., 2007), and (2) the Index of Economic Freedom, published by the Heritage Foundation ( 2005). These indices contain some similar measures; however, they are constructed differently. This difference in construction may lead to conflicting results when comparing studies that use different indices. Therefore, we do not know if the relationship between institutions and entrepreneurship is robust across the different indices or if it is just an artifact of the measure being used. 
In this essay, I examine the following research question: Does a country's formal institutional environment influence the likelihood that individuals are engaged in selfemployment? Baumol (1990) argues that the institutional environment has a profound impact on entrepreneurship. This essay adds to previous research by examining how individual-level moderators of this relationship, such as regulatory focus and human capital, influence self-employment. This essay has implications for public policy as well. Some empirical evidence indicates that job creation (Fölster, 2000) and economic growth (Carree, van Stel, Thurik, \& Wennekers, 2002) might become impaired when selfemployment levels become too low. Thus, it is important for policy makers to assure that the institutions in their country do not hamper the ability of individuals to become selfemployed.

This essay starts by reviewing the literature concerning institutions and entrepreneurship and by developing hypotheses concerning how the formal institutional environment influences the likelihood that individuals engage in self-employment. Furthermore, I develop several hypotheses predicting cross-level interaction effects, focusing on how institutions interact with an individual's regulatory focus and human capital to determine the likelihood of self-employment. Finally, I use data from the Global Entrepreneurship Monitor (GEM) dataset to test the hypotheses.

\subsection{INSTITUTIONS AND ENTREPRENEURSHIP}

The institutional environment influences many outcomes in an economy, including economic growth (Barro, 1996; De Haan \& Sturm, 2000; Rodrik et al., 2004) and the level of entrepreneurship (McMullen et al., 2008; Ovaska \& Sobel, 2005). The 
institutional environment may also affect the amount of productive and unproductive entrepreneurship that exists (Baumol, 1990; Sobel, 2008). As North (1990) states:

"Institutions are the rules of the game in a society or, more formally, are the human devised constraints that shape human interaction. In consequence they structure incentives in human exchange, whether political, social, or economic" (p. 3).

Therefore, institutions set the "rules of the game" in an economy; determine incentives, reduce uncertainly, and influence transaction costs (North, 1987).

Institutions can be both formal and informal (North, 1990). Informal institutions (or informal constraints) include norms, social conventions, codes of behavior, and customs, which originate from the experience, routines, culture, and religious beliefs of a society (Klein, 2000; Pejovich, 1998; Williamson, 2000). Formal institutions are the rules developed by human beings, such as constitutions and statutory law (North, 1990; Williamson, 2000). Informal and formal institutions are closely and causally related to one another. Norms, customs, and traditions (informal institutions) influence the laws and the constitution a country adopts (formal institutions). Furthermore, the laws of a country may influence its norms, customs, and traditions. For example, changes in social norms lead to increased tobacco taxes and regulations in the United States, and yet it is likely that increased regulations have influenced the norms regarding smoking, making smoking less socially acceptable (Hamilton et al., 2008; Nyborg \& Rege, 2003). Informal and formal institutions typically differ in how quickly they change. While informal institutions can last centuries, formal institutions typically change more often 
(Williamson, 2000), although they vary greatly with respect to how quickly they change. While the U.S. Constitution was created over a short period of time, other institutions, such as British common law, evolved over a much longer period (North, 1990).

Although there is a close relationship between informal and formal institutions and both may have an impact on entrepreneurship, this essay will focus exclusively on how formal institutions in a country affect entrepreneurship. Hereafter, the term "institutions" will refer exclusively to formal institutions.

\subsection{MODEL OF ENTREPRENEURIAL ACTIVITY}

To predict how institutions affect the self-employment decision, it is necessary to understand why people flow in and out of self-employment. I use a model similar to Gimeno, Folta, Cooper, and Woo (1997) to predict exit from self-employment to wage employment. I also modify this model to explain entry into self-employment from wage employment.

\section{Switching from Self-Employment to Wage Employment}

In their model, Gimeno et al., (1997) assume an individual compares the threshold level of performance to the actual economic performance of her business to determine whether to continue the venture. The threshold level of performance is the minimum performance that he or she requires from the venture to keep operating it. The threshold performance is a function of the opportunity cost associated with other forms of employment, the cost of switching occupations (from self-employment to the new occupation), and the difference in psychic income between continuing self-employment 
and other possible sources of employment. Figure 2.1 displays a simplified version of the model.

Figure 2.1: Model of Entrepreneurial Exit Adopted from Gimeno, Folta, Cooper and Woo (1997)

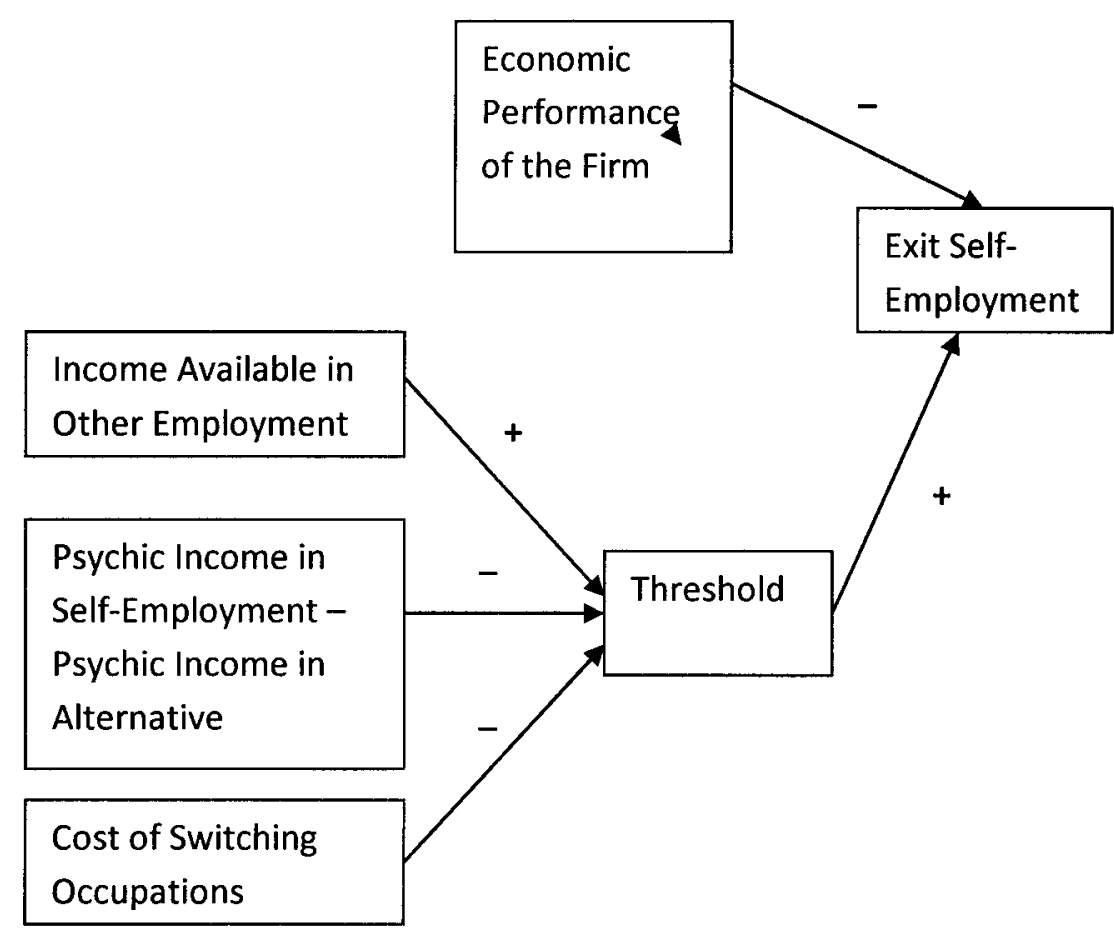

When the expected economic performance of a venture is higher than the threshold level of performance, an individual will continue to be self-employed. When the expected economic level of performance falls below the threshold level of performance, the firm is abandoned, and the individual leaves self-employment for wage employment. Threshold performance is determined by three factors. The first is income available from other sources of employment, or the opportunity cost of being selfemployed. If the individual can earn a substantial return in wage employment, then the 
threshold level of their business will be high. The second factor is the difference between the psychic income from self-employment and the psychic income from alternative employment. If the individual enjoys self-employment more than wage employment then this difference will be large, and will further increase the threshold level of performance. Psychic income can be substantial for the self-employed (Hamilton, 2000). The third factor is the switching cost associated with moving from self-employment to wage employment. High switching cost will increase the threshold level of performance (Gimeno et al., 1997).

An individual will discontinue the business and become a wage earner when the expected utility of operating the entrepreneurial venture $\left(U_{E}\right)$ is less than the utility of alternative employment $\left(\mathrm{U}_{\mathrm{A}}\right)$ minus the associated cost of switching from selfemployment to alternative employment $\left(\mathrm{SC}_{\mathrm{EA}}\right)$ :

$$
\mathrm{U}_{\mathrm{E}}<\left(\mathrm{U}_{\mathrm{A}}-\mathrm{SC}_{\mathrm{EA}}\right)
$$

$\mathrm{U}_{\mathrm{E}}$ is determined by the expected economic performance of the venture $\left(\mathrm{EP}_{\mathrm{E}}\right)$ plus the psychic income that the individual obtains from operating the venture $\left(\mathrm{PI}_{\mathrm{E}}\right) . \mathrm{EP}_{\mathrm{E}}$ is a function of the entrepreneur's general human capital $\left(\mathbf{X}_{\mathbf{1}}\right)$ and his or her human capital specific to the current firm $\left(\mathbf{X}_{2}\right)$. $\mathrm{PI}_{\mathrm{E}}$ is a function of a number of individual characteristics $\left(\mathbf{X}_{\mathbf{4}}\right)$.

$$
\mathrm{U}_{\mathrm{E}}=\mathrm{EP}_{\mathrm{E}}\left(\mathbf{X}_{\mathbf{1}}, \mathbf{X}_{\mathbf{2}}\right)+\mathrm{PI}_{\mathrm{E}}\left(\mathbf{X}_{\mathbf{4}}\right)
$$

The expected utility of alternative employment $\left(\mathrm{U}_{\mathrm{A}}\right)$ is determined by the expected economic performance of alternative employment $\left(\mathrm{EP}_{\mathrm{A}}\right)$ plus the psychic 
income that the individual obtains from alternative employment $\left(\mathrm{PI}_{\mathrm{A}}\right) . \mathrm{EP}_{\mathrm{A}}$ is a function of the entrepreneur's general human capital $\left(\mathbf{X}_{1}\right)$ and his or her human capital specific to alternative employment $\left(\mathbf{X}_{\mathbf{3}}\right)$. The $\mathrm{PI}_{\mathrm{A}}$ is a function of a number of individual characteristics $\left(\mathbf{X}_{\mathbf{5}}\right)$.

$$
\mathrm{U}_{\mathrm{A}}=\mathrm{EP}_{\mathrm{A}}\left(\mathbf{X}_{\mathbf{1}}, \mathbf{X}_{\mathbf{3}}\right)+\mathrm{PI}_{\mathrm{A}}\left(\mathbf{X}_{\mathbf{5}}\right)
$$

Subsituting (2) and (3) into (1) yields the combined model:

$$
\left[\mathrm{EP}_{\mathrm{E}}\left(\mathbf{X}_{\mathbf{1}}, \mathbf{X}_{\mathbf{2}}\right)+\mathrm{PI}_{\mathrm{E}}\left(\mathbf{X}_{\mathbf{4}}\right)\right]<\left(\mathrm{EP}_{\mathrm{A}}\left(\mathbf{X}_{\mathbf{1}}, \mathbf{X}_{\mathbf{3}}\right)+\mathrm{PI}_{\mathrm{A}}\left(\mathbf{X}_{\mathbf{5}}\right)-\mathrm{SC}_{\mathrm{EA}}\right]
$$

Thus, an entrepreneur will close a firm when the expected utility gained from operating the venture becomes less than the expected utility of alternative employment minus the cost of switching from entreprneuership to alternative employment. The expected utility the entrepreneur recieves from the venture is derived from both the economic performance of the venture as well as the psyhic income of operaing the venture. Likewise, the expected utility of alternative employment is due to both the economic performance and psychic income of alternative employment.

\section{Switching from Wage Employment to Self-Employment}

Although the model developed by Gimeno et al. (1997) is used to predict whether a self-employed individual will switch to an alternative form of employment, the same factors can be used to predict if an individual who is currently engaged in wage (alternative) employment will switch into self-employment. An individual will discontinue wage employment and start a venture when the utility of alternative 
employment $\left(\mathrm{U}_{\mathrm{A}}\right)$ is less than the utility of self-employment $\left(\mathrm{U}_{\mathrm{E}}\right)$ minus the cost of switching from alternative employment to self-employment $\left(\mathrm{SC}_{\mathrm{AE}}\right)$ :

$$
\mathrm{U}_{\mathrm{A}}<\left(\mathrm{U}_{\mathrm{E}}-\mathrm{SC}_{\mathrm{AE}}\right)
$$

$\mathrm{U}_{\mathrm{A}}$ is determined by the expected economic performance of alternative employment $\left(\mathrm{EP}_{\mathrm{A}}\right)$ plus the psychic income that the individual obtains from alternative employment $\left(\mathrm{PI}_{\mathrm{A}}\right) \cdot \mathrm{EP}_{\mathrm{A}}$ is a function of the individual's general human capital $\left(\mathbf{X}_{1}\right)$ and his or her human capital specific to alternative employment $\left(\mathbf{X}_{\mathbf{3}}\right)$. $\mathrm{PI}_{\mathrm{A}}$ is a function of a number of individual characteristics $\left(\mathbf{X}_{\mathbf{5}}\right)$.

$$
\left[\mathrm{EP}_{\mathrm{A}}\left(\mathbf{X}_{\mathbf{1}}, \mathbf{X}_{\mathbf{3}}\right)+\mathrm{PI}_{\mathrm{A}}\left(\mathbf{X}_{\mathbf{5}}\right)\right]<\left[\mathrm{EP}_{\mathrm{E}}\left(\mathbf{X}_{\mathbf{1}}, \mathbf{X}_{\mathbf{2}}\right)+\mathrm{PI}_{\mathrm{E}}\left(\mathbf{X}_{\mathbf{4}}\right)-\mathrm{SC}_{\mathrm{AE}}\right]
$$

Equation 6 displays the combined equation. The expected performance of the venture $\left(E P_{E}\right)$, the expected performance of alternative employment $\left(\mathrm{EP}_{\mathrm{A}}\right)$, and switching costs (both $\mathrm{SC}_{\mathrm{EA}}$ and $\mathrm{SC}_{\mathrm{AE}}$ ) are likely to be influenced by the institutional environment.

\subsection{INSTITUTIONS AND THE LIKELIHOOD OF SELF-EMPLOYMENT}

The institutions in a country influence the likelihood that an individual will switch into or out of self-employment. I examine the institutional factors associated with economic freedom, which have been found to affect the level and type of entrepreneurship in an economy (Campbell \& Rogers, 2007; Nyström, 2008; Sobel, 2008). Economic freedom refers to the extent to which property rights are protected and voluntary transactions and competition are allowed in an economy (Gwartney et al., 2007). An economy is economically free when governments protect private property and do not burden economic actors with high levels of taxation or business regulation. 
Institutional factors associated with economic freedom include government size/taxation, the level of business regulation, the level of restrictions on international trade, the protection of property rights, and the soundness of money.

\section{Government Size and Taxation}

Government size may affect the costs and benefits associated with selfemployment in several ways. Small governments require less tax revenue to operate. Large governments require more revenue and often tax businesses in a number of ways to generate the needed funds. For self-employed people, business profits are often taxed at personal income rates (Carroll, Holtz-Eakin, Rider, \& Rosen, 2001). In countries with progressive income taxes, self-employed individuals with high incomes face high marginal tax rates (Wolff, 1998). These high tax rates may reduce the incentive for individuals engaging in entrepreneurship. In addition, governments may choose to tax the self-employed in ways other than income taxes. These include capital gains tax, user fees, business license fees, etc. (Bruce \& Mohsin, 2006; Djankov, La Porta, Lopez-DeSilanes, \& Shleifer, 2002). As governments grow larger, they will likely increase many of these different taxes in order to fund themselves.

In addition to high taxes limiting the potential return of self-employment, they may also reduce people's ability to become self-employed because high taxes may exacerbate liquidity constraints (Fölster, 2002). Liquidity constraints occur when individuals or firms have profitable opportunities that they would like to exploit but cannot due to a lack of the capital necessary for opportunity exploitation. Although the idea of liquidity constraints deterring entry into self-employment and firm growth is a 
controversial one, some support has been found in industrialized countries (Dunn \& Holtz-Eakin, 2000; Johansson, 2000; Lindh \& Ohlsson, 1996), and any effect is likely even more pronounced in countries with less developed capital markets. Because high taxes reduce the amount of cash retained by an individual or firm, prospective entrepreneurs may choose not to start new firms and may limit the extent to which existing ones expand (Fölster, 2002). If high levels of taxation increase the liquidity constraint, then higher taxes in an economy are likely to be associated with lower levels of self-employment.

Small governments are less involved in the economy compared to larger ones. When governments are large, their presence in the economy may crowd out private firms and deter new firms from entering the market. A large government may play a role in industries that are typically not entered by smaller governments. Larger governments often enter and compete in certain industries, such as education, air travel, and healthcare (Poterba, 1995; Salvatore, 2003). For example, in the United States as well as many other countries, the government operates substantially in the education industry, with a strong presence in primary, secondary, and post-secondary education (Heller \& Rogers, 2006). Although post-secondary education in the United States is provided by a number of private colleges and universities as well as public colleges and universities, public colleges and universities enroll a substantially larger number of students (Eckel \& King, 2004). Government subsidization of education makes it difficult for private firms to compete because they must charge students substantial tuition; whereas, students may attend government schools for free, or in the case of post-secondary schools, at a 
subsidized rate. The more industries in which the government is involved, the fewer opportunities there will be for entrepreneurs to exploit (Gohmann, Hobbs, \& McCrickard, 2008).

Empirical research on the relationship between government size/taxation levels and levels of entrepreneurship finds mixed results. Wennekers, van Stel, Thurik, and Reynolds (2005) found that the ratio of tax revenue to GDP is positively related to the nascent entrepreneurship rate across countries. However, several other studies found a negative relationship between government size/taxation levels and entrepreneurship. Using data from 23 OECD countries from 1972 to 2002 Nystrom (2008) found that government size, using the measure from the Economic Freedom of the World index (EFW), is negatively related to self-employment. Bjornskov and Foss found that government size (EFW measure) is negatively associated with the total entrepreneurial activity rate (a country's self-employment rate plus the nascent entrepreneurship rate) using data from 29 countries. Furthermore, they found that government size is negatively associated with entrepreneurship that is undertaken to exploit a lucrative opportunity (opportunity-motivated entrepreneurship) as well as entrepreneurship that is undertaken due to personal necessity (necessity-motivated entrepreneurship), thus finding that large governments deter both types of entrepreneurship. Aidis, Estrin, and Mickiewicz (2009) found that a limited state sector is positively associated with nascent entrepreneurial entry. Likewise, Kreft and Sobel found a negative relationship between tax burden measure from the Economic Freedom of North American (EFNA) index and the sole proprietor growth rate in U.S. states. 
In summary, small government demands less tax revenue from their citizens, giving them the ability and more incentive to start and operate their own firms. Furthermore, small governments are less likely to compete directly with private firms in certain industries, leading to more areas in which entrepreneurs can pursue opportunities. Much of the existing research shows a negative relationship between government size/taxation levels and measures of entrepreneurship.

\section{H1: There is a negative relationship between the size of government/level of taxation in the country in which an individual resides and the likelihood that he or she will be self-employed.}

\section{Level of Business Regulation}

Governments can regulate businesses in a number of ways: by making it difficult to obtain a business license, by setting price controls, or by restricting firm entry (Brunetti, Kisunko, \& Weder, 1997; Gwartney et al., 2007). These sorts of regulations can vary widely across countries. For example, meeting the government requirements for starting a business in Italy requires that the prospective entrepreneur perform 16 procedures, wait 62 days, and pay the equivalent of $\$ 3,946$ in fees. Alternatively, in Canada this task can be performed in 2 days with an equivalent of $\$ 280$ in fees (Djankov et al., 2002). Clearly, such regulations have direct and indirect costs and may play a large role in deterring individuals from starting new firms.

If entry regulations are burdensome, new firms may find it difficult to enter the formal sector of the economy. The formal sector of the economy refers to the part of the 
economy subject to regulation, in which taxes are levied, wages are regularly paid, and the relationship between workers and employers is governed by explicit contracts (Pradhan \& Van Soest, 1995). The informal sector does not feature these attributes, and many firms in the informal sector engage in ethically questionable or illegal activities. This may lead to a number of outcomes, including a formal sector made up mostly of larger already existing firms. Large amounts of regulation regarding starting a new business tend to increase the size of an economy's informal economy and decrease the size of its formal economy (De Soto, 1989). The size of the informal sector has been shown to vary greatly by country; making up only around $9.4 \%$ of the economy in Denmark while constituting around $76 \%$ of the economy in Nigeria (Antunes \& Cavalcanti, 2007; Friedman, Johnson, Kaufmann, \& Zoido-Lobation, 2000). Although entrepreneurship may still exist in the informal sector, starting a new firm in this sector may be much less feasible because firms in the informal sector often lack securable collateral and, therefore, access to capital that firms in the formal sector can obtain (Antunes \& Cavalcanti, 2007). Furthermore, entrepreneurship in the informal sector is unlikely to have the social benefits that formal sector firms have in terms of leading to greater economic growth, greater human capital investment and greater employment. Thus, a large informal sector in an economy is likely to retard the creation of new firms and self-employment.

Another way in which governments often regulate firms is by regulating the relationship between firms and employees. This is done through legislating minimum wages, forcing firms to pay overtime, making firms pay severance packages to dismissed 
employees, and protecting labor unions (Emerson, 1988; Freeman, 2007; Gwartney et al., 2007). These rules increase the cost of hiring. These rules may influence the decision of individuals whether to become self-employed by increasing the cost of switching to selfemployment. According to results from the Panel Study of Entrepreneurial Dynamics, the median firm plans to have two employees in addition to the owner within the first year of business operations (Human \& Matthews, 2004). Because most new firms plan on hiring paid employees and doing so relatively quickly, the costs of hiring employees will likely influence individuals when deciding whether to start a new firm.

Several empirical studies examine the relationship between business regulation and entrepreneurship. McMullen, Bagby, and Palich (2008) use both the level of business regulation and labor market freedom measures from the Index of Economic Freedom (IEF) index to predict the level of entrepreneurship in 37 countries included in the 2002 GEM survey. Measures of entrepreneurship used included entrepreneurship undertaken in order to exploit a lucrative opportunity (opportunity-motivated) as well as entrepreneurship undertaken due to personal necessity (necessity-motivated). They found that business regulation is not associated with entrepreneurship. Likewise, Bjornskow and Foss (2008) found no relationship between the level of business regulations and measures of entrepreneurship. However, other researchers have found a negative relationship between business regulations and entrepreneurship. Klapper, Laeven and Rajan (2006) examine the relationship between entry barriers and entrepreneurship using the Amadeus database, which contains firm-level data from more than five million firms in 34 European countries. They found that costly regulations are negatively related to the 
creation of new firms, and this is even truer in industries that have naturally high entry barriers. Van Stel, Storey, and Thurik (2007) examine how business regulations impact nascent and young businesses, with regulatory variables taken from the World Bank Doing Business (WBDB) database. They found that hours rigidity (restrictions on expanding or contracting the number of working hours) and employment rigidity (difficulty of hiring and firing) negatively relate to the measures of entrepreneurship. Sobel, Clark, and Lee (2007) used the Global Entrepreneurship Monitor (GEM) measure of total entrepreneurial activity (TEA) index to examine the relationship between institutions and entrepreneurship. Domestic entry restrictions were measured using a variable "administrative burden for startups" from The Global Competitiveness Report. Internal barriers to entry are negatively related to TEA, and this relationship is robust when other measures of governmental barriers are included in the analysis. Finally, Nystrom (2008) also found that low levels of business regulation are associated with high rates of self-employment in OECD countries.

Direct regulations regarding starting and operating a business, as well as those involving the employment relationship, increase the cost of starting and operating a business. Thus, business regulations are likely to increase the cost of switching from wage employment to self-employment and may also lower the expected returns to selfemployment.

\section{H2: There is a negative relationship between the level of business regulation in the country in which an individual resides and the likelihood that he or she will be self-employed.}




\section{Freedom to Trade}

A country that lacks trade freedom will typically have high tariffs as well as nontariff barriers, such as quotas, subsidies, and bans on trade (Gwartney et al., 2007). Although free trade has expanded greatly in recent history (Bergsten, 2001), many trade restrictions still exist (Gibson, Wainio, Whitley, \& Bohman, 2001; Schnepf \& Womach, 2008).

The impact that trade freedom has on self-employment is not obvious. In one sense, substantial trade restrictions may actually increase the opportunity for firms to produce goods and services for domestic consumption because protectionist measures may make it difficult for foreign firms to enter and operate in the market. This would allow domestic firms to charge higher prices or offer lower quality products (Dardis, Spivak, \& Shih, 1985; Nguyen-Hong, 2000). Furthermore, firms that are new and/or small may not have adequate resources to take advantage of the opportunities that appear when trade barriers are minimized. Julien, Joyal and Deshaies (1994) found that globalization hurt small and medium sized firms because lower productivity makes it more difficult to compete in the global marketplace. Their limited resources make it difficult for them to exploit opportunities that arise in foreign markets due to the relaxation of tariffs. Campbell (1996) found that many small exporting firms are not positioned correctly to benefit from the increasing numbers of opportunities that come about as a result of increased trade freedom. Therefore, trade restrictions may actually encourage self-employment for some individuals. 
However, substantial trade restrictions may also create fewer opportunities for domestic firms to have their product or service sold in another country. Trade agreements are often reciprocal in nature; when a country has extensive trade barriers that keep foreign firms from entering the domestic market, foreign countries will often place trade restrictions against products from the protectionist country (Anderson, 2002; Gawande \& Hansen, 2003). Likewise, countries often agree to lower trade barriers simultaneously through free trade agreements, as can be seen with the North American Free Trade Agreement and various World Trade Organization agreements (What is the World Trade Organization?, 2009; Brown, Deardorff, \& Stern, 1992). Therefore, substantial trade restrictions in a country will likely lead to other countries having substantial restrictions against that country.

Trade allows markets for goods and services to expand, allowing firms to specialize (Smith, 1776). Free trade between countries allows firms to specialize in producing a product or service and export their product or service around the world. Firms that do businesses globally often start exporting early in their life (Moen \& Servais, 2002), indicating that globalization may often be a part of the earliest plan for a new firm. The term "born global" has gained notoriety with researchers because empirical evidence suggests that many new firms are engaging in business beyond their home country as soon as they are open (Andersson \& Evangelista, 2006; Moen, 2002). If these new ventures face substantial trade barriers when attempting to conduct business abroad, they will be at a cost disadvantage to domestic firms in those markets and may find doing business there unattractive. As doing business in foreign markets becomes 
less attractive for domestic firms, the economic performance of these firms or the expected economic performance of prospective new firms is likely to fall. Additionally, extensive trade restrictions could make engaging in self-employment less economically beneficial in other ways. When trade restrictions are substantial, they increase the cost of products to consumers (Cox \& Harris, 1985; Dardis et al., 1985; Irwin, 2003; Langerfeld \& Nieberding, 2005). Firms are consumers of many products, such as capital investments and inventory/raw materials that are likely to be more expensive when trade restrictions are significant.

Empirical research on the relationship between trade freedom and entrepreneurship has been mixed. Sobel, Clark, and Lee (2007) found that the average tariff rate is negatively related to total entrepreneurial activity and is robust when other measures of governmental barriers were included in the analysis. However, other research shows a non-significant relationship between trade freedom and measures of entrepreneurship (McMullen et al., 2008; Nyström, 2008). Although trade restrictions may increase the level of self-employment in a country by creating opportunities for producing items that are restricted, in other ways, such restrictions also may lead to the destruction of business opportunities and may make some business opportunities less profitable. Overall, freer trade gives the entrepreneur more opportunities to sell their products or services. Therefore, it is likely that trade freedom will increase the likelihood that individuals will be engaged in self-employment. 


\section{H3: There is a positive relationship between the level of trade freedom in the country in which an individual resides and the likelihood that he or she will be self-employed.}

\section{Property Rights}

According to Demsetz (1967), "an owner of property rights possesses the consent of fellowmen to allow him to act in a particular way" (p. 347). Property rights are important because they structure the incentives in a manner that helps internalize externalities (Demsetz, 1967). Property rights is a rather broad term, but generally property rights are considered strong when the government protects private property, the court system enforces contracts, and there is little expropriation of property (Index of economic freedom, 2005).

From an individual's perspective, well-defined property rights reduce the uncertainty regarding the use of property (Barzel, 1997; Demsetz, 1967). For example, a government seizing private property and failing to compensate the owner for it will impact the level of risk that property owner's face and will influence their behavior. As a result, property owners will tend to underinvest in improving their property. Besley (1995) found empirical support for the relationship between land rights and investment (measured by land improvements such as planting trees, irrigating, and mulching the land) in Ghana. Examining a sample of manufacturing firms in Eastern Europe, Johnson, McMillian \& Woodruff (2002) found that investment is retarded by weak property rights.

Claessens \& Laeven (2003) found that stronger property rights leads to higher firm growth due to the fact that firms do a better job of allocating assets. 
In many ways, the decision to become self-employed is a decision of how an individual should invest his or her time and resources. This investment decision will likely be influenced by the strength of the property rights in the location where the individual resides. When people become self-employed and start a new venture, they must invest capital in their business. When property rights are weak, business investment is deterred because those who are self-employed or thinking of becoming self-employed do not know whether they will be able to keep any profits they may obtain (Johnson et al., 2002). Therefore, it is expected that strong property rights protection in a country will increase the probability that people in that country will engage in self-employment.

Bjornskov and Foss (2008) failed to find a significant relationship between the quality of the legal system and entrepreneurial activity. However, other researchers have found a positive relationship between measures of the strength of property rights and entrepreneurship. Nystrom (2008) found that secure property rights are positively related to the rate of self-employment. McMullen, Bagby, and Palich (2008) found that strong property rights are associated with higher levels of opportunity-motivated entrepreneurship but are not significantly related to rates of necessity-motivated entrepreneurship.

\section{H4: There is a positive relationship between property rights protection in the country in which an individual resides and the likelihood that he or she will be self-employed.}




\section{Sound Money}

An economy is said to have sound money when the inflation rate is low and has little volatility (Gwartney \& Lawson, 2003). Although there is often thought to be a positive relationship between the inflation rate and inflation volatility ${ }^{2}$, these two issues will be examined separately.

It is important for future inflation rates to be known with some degree of certainty because, like property rights, inflation rates allow individual actors to have consistent expectations about what prices to expect in the future. High volatility in the inflation rate makes planning for the future and making investment decisions difficult because the actual net present value of future projects will be difficult to determine (Huizinga, 1993). Typically, when a contract is written, any inflation expectation is inferred in the terms of the contract (Holland, 1984). The most obvious example of this is the mortgage contract between a borrower and a bank. While the interest rate may be $7 \%$, the lending bank may only require a real $4 \%$ return but includes a $3 \%$ premium for expected inflation. Once a contract is agreed to, if actual inflation is higher than expected inflation, then those making payments (the borrowers) receive a gain while those receiving payments (the lending banks) receive a loss (Holland, 1984). If inflation uncertainty is high, writing contracts to account for this variable inflation will be more

\footnotetext{
${ }^{2}$ There has been some debate to what degree high inflation and inflation volatility are related. Although some research indicates a strong relationship between inflation rate and inflation uncertainty, Holland (1984) found somewhat more mixed results. However, the two concepts can be made conceptually distinct, even if they often occur together.
} 
difficult. Firms and individuals will likely be hesitant to enter into contracts, and those entered into will likely be shorter term (Rich \& Tracy, 2004).

Although uncertain inflation rates can lead to problems in making investment decisions, consistent inflation rates also are problematic if they are excessively high. High levels of inflation have been found to lead to a number of negative economic outcomes, such as reduced common stock returns (Fama, 1981), low economic growth (Bruno \& Easterly, 1998), and even high levels of unemployment (Friedman, 1977). High levels of inflation raise the rate of return required for business investments (Nelson, 1976), therefore making starting or operating a business less attractive.

Both a high rate of inflation and inflation volatility lead to an undesirable economic environment that becomes risky for those engaging in long-term transactions (Huizinga, 1993; Nelson, 1976). Being self-employed often requires that individuals agree to long-term contracts, and many business investments that are made by the selfemployed are long-term. It may seem that the self-employed would benefit from high inflation rates because they are often borrowing money and signing long-term lease agreements in which they would actually gain from high levels of inflation. However, if a country traditionally has a high level of inflation, it is likely to be priced into any loan or lease contract, which would make the agreement expensive (Holland, 1984). When a country suffers from high or uncertain levels of inflation, the inflation risk will raise the threshold level of performance required by those currently self-employed to remain selfemployed and will lower the attractiveness of pursuing opportunities in self-employment by those who are not currently self-employed. 
Nystrom (2008), however, found no relationship between sound money and selfemployment, while McMullen et al. (2008) found mixed results. Conversely, Bjornskov and Foss (2008) found a positive relationship between sound money and (1) the opportunity-motivated entrepreneurship rate, (2) the necessity-motivated entrepreneurship rate, and (3) the total entrepreneurial activity rate.

H5: There is a positive relationship between the soundness of money in the country in which an individual resides and the likelihood that he or she will be self-employed. 
Figure 2.2: Hypothesized Relationships between Institutions and Likelihood of Engaging in Self-Employment

\section{Country-Level}

Predictors:

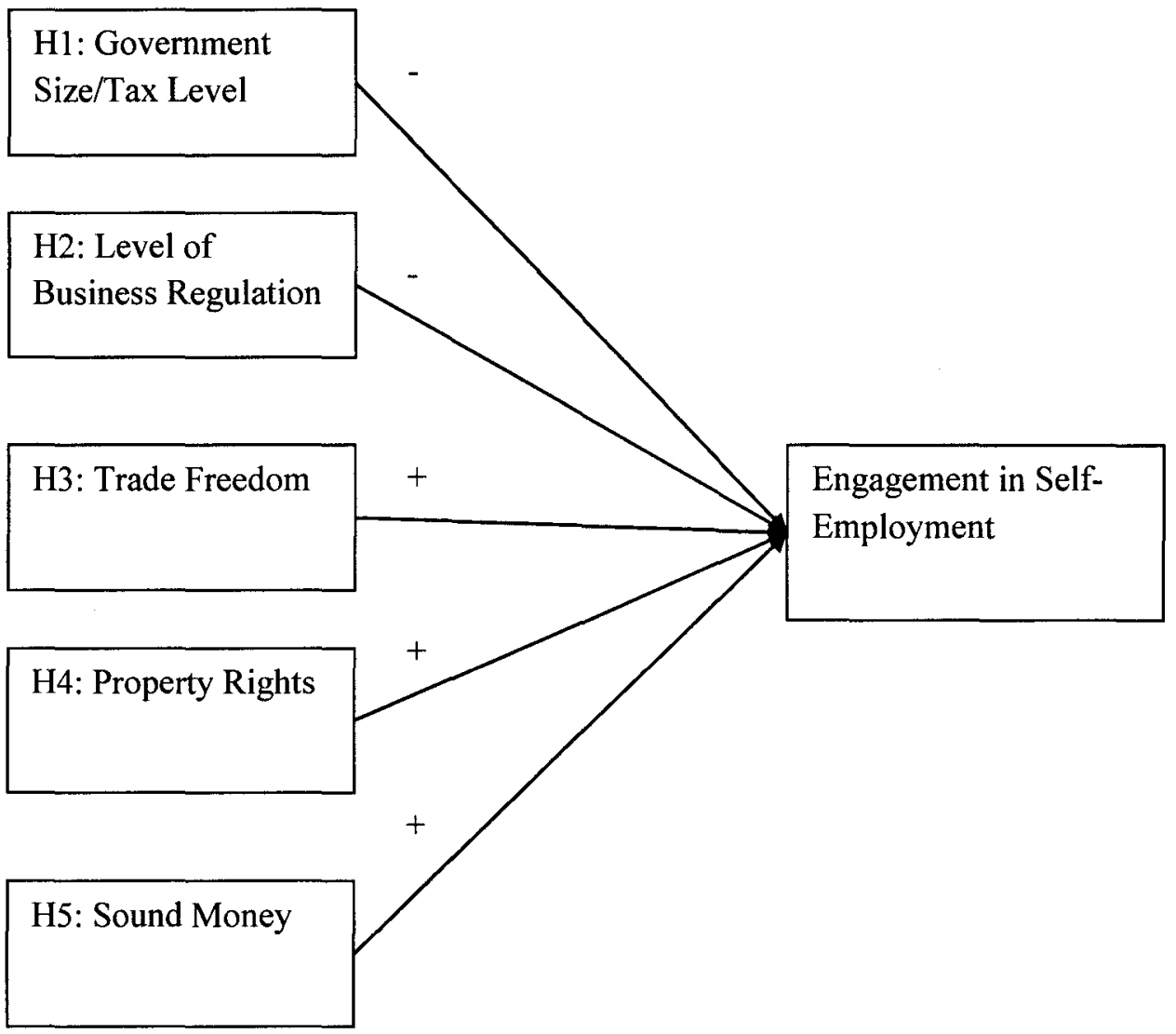

\subsection{INSTITUTIONS AND THE LIKELIHOOD OF SELF-EMPLOYMENT:} MODERATING EFFECTS

The institutional environment of a country may interact with characteristics of individuals to influence the likelihood that they are self-employed. I examine two individual-level factors that are likely to interact with institutional factors to influence the 
individual's choice between self-employment and wage employment: an individual's regulatory focus and their human capital level.

\section{Regulatory Focus}

Regulatory focus theory argues that an individual can adopt two possible strategies when working to achieve a goal: a promotion focus or a prevention focus (Brockner, Higgins, \& Low, 2004; Förster, Higgins, \& Idson, 1998). When individuals have a promotion focus, they focus on pursuing possible gains and concern themselves little with possible losses. Individuals with a prevention focus emphasize minimizing possible losses even if doing so minimizes possible gains. If an individual is preventionfocused concerning engagement in entrepreneurship, he or she will worry about the possibility of failure and will act in a way that minimizes this possibility, even at the cost of possible gains. Individuals use a promotion focus when they have a desire for accomplishment and progress and adopt a prevention focus when they desire security and safety (Crowe \& Higgins, 1997). In the literature, there has been some debate to what degree an individual's regulatory focus is chronic (a long-lasting trait) or determined by context (McMullen \& Zahra, 2006).

The higher the psychic income an individual receives from being self-employed, the more likely that he or she is to enter self-employment (or remain self-employed if already self-employed; (Gimeno et al., 1997). Because operating an independent business is risky and a substantial number of new firms do fail (Evans \& Leighton, 1989; Phillips \& Kirchhoff, 1989), those who approach owning a business with a prevention focus will derive less psychic income from self-employment than those who have a 
promotion focus. Thus, prevention-focused individuals will be less likely to become or to continue to be self-employed.

\section{Sound Money and Regulatory Focus}

A country has sound money when the inflation rate is low and has little volatility (Gwartney \& Lawson, 2003). A sound currency allows those who are self-employed to make more certain investment decisions (Huizinga, 1993) such as whether to hire an employee or whether to purchase equipment. However, when the currency in a country is not stable, the long-term decisions that self-employed individuals must make are very risky because volatile inflation rates make it difficult to determine the financial returns to self-employment ex ante.

When an individual is deeply concerned about the possibility of failure in selfemployment, he or she is less likely to be self-employed, and this is likely to be true regardless of the environment that he or she finds themselves in. If a person is prevention-focused with regard to a certain activity, he or she may be willing to take small, calculable risks but not willing to take large risks that are difficult to control for (Brockner et al., 2004). Therefore, if an individual has a strong prevention focus when it comes to engaging in self-employment, he or she may still be willing to engage in selfemployment if environmental conditions make the risk associated with self-employment predictable and manageable. However, if environmental conditions are such that the risk of owning a business is magnified, then a prevention-focused individual may be even more likely to avoid or leave self-employment. The increased risk of operating a business that is present when a country's currency is not sound is likely to 
disproportionally deter an individual who is prevention-focused from being selfemployment. Thus, if a prevention-focused individual resides in a country in which the money is not sound, he or she will be less likely to engage in self-employment than a prevention-focused individual that resides in a country that has a sound and stable currency.

H6: The negative relationship between prevention focus and the likelihood of self-employment will be stronger for individuals in countries without sound money than individuals in countries with sound money.

\section{Property Rights and Regulatory Focus}

Strong property rights exist when courts are fair and efficient and when property is not expropriated without just cause and appropriate compensation (Index of economic freedom, 2005). Strong property rights protections are important because they shape incentives and reduce uncertainty (Barzel, 1997; Demsetz, 1967). Thus, strong property rights are essential to encourage investments (Besley, 1995). If individuals become selfemployed and start a new business, they will make substantial investments that may be lost if their country does not provide strong protection of their property rights (Johnson et al., 2002). Weak property rights protection is likely to deter people from entering selfemployment and encourage those currently self-employed to exit. However, this effect will likely vary for differing individuals, depending on their personal characteristics.

Like with sound money, the presence of strong property rights reduces the amount of risk in transactions and in conducting business (Barzel, 1997; Demsetz, 1967). 
Individuals who are prevention-focused will be particularly sensitive to the level of property rights in their country when determining whether to become or continue to be self-employed. This is because weak property rights are likely to reduce the psychic income that prevention-focused individuals derive from self-employment because these individuals will be worried about the possible losses that they may incur and thus will seek less enjoyment from self-employment. As the psychic income derived from selfemployment decreases, individuals are more likely to leave self-employment for wage employment (Gimeno et al., 1997). Thus, those who are prevention-focused will be less

likely to engage in self-employment when property rights protections are weak than those who are not prevention-focused.

\section{H7: The negative relationship between prevention focus and the likelihood of self-employment will be stronger for individuals in countries with weak property rights than individuals in countries with strong property rights.}

\section{Human Capital}

An individual's level of human capital influences the likelihood that he or she will engage in entrepreneurship (Bates, 1995; Davidsson \& Honig, 2003). One component of an individual's general human capital is formal education (Becker, 1975). The relationship between education and self-employment is complex. Those with high levels of education are generally more likely than others to be self-employed (Caputo \& Dolinsky, 1998; Fairlie, 1999; Rees \& Shah, 1986; Reynolds, 2004). Many people with professional degrees work in areas where self-employment is common, such as in medicine or law. Also, a high level of education gives an individual certain skills that 
may be helpful in starting and operating a business, such as writing, critical thinking, and management skills. Some empirical research suggests that those with higher levels of human capital are more successful as entrepreneurs than those with lower levels of human capital (Bates, 1990; Cooper, Gimeno-Gascón, \& Woo, 1997).

However, Blanchflower (2000) found that the relationship between education and self-employment is non-linear, that those with the lowest and highest levels of education were more likely to be self-employed than those with an average level of education. Those with a low level of education may be likely to be self-employed because they may have difficulty in finding a job and are "pushed" into self-employment out of necessity. Although the opportunities that individuals with low human capital may pursue may be limited, their opportunity costs are limited as well.

\section{Government Size/Taxation Levels and Human Capital}

Large governments tax their citizens more to pay for the services that they provide (Anderson, Wallace, \& Warner, 1986; Esping-Andersen \& Korpi, 1987). High taxation also reduces the incentive to engage in certain activities that have the possibility of high returns, such as self-employment (Fölster, 2002). Although this generally reduces the incentives of individuals in a country to engage in entrepreneurship, it is likely to affect those with high levels of human capital the most adversely. For selfemployed people, business profits are often taxed at personal income rates (Carroll et al., 2001), and individuals with higher levels of human capital are likely to have high earnings from their business (Evans \& Leighton, 1989; Hundley, 2000). Therefore, these individuals will likely be taxed at a higher tax rate than those with less human capital, 
who are likely earning less from self-employment. Typically, governments with high levels of taxation have tax rates that are quite progressive, taxing wealthy individuals at higher rates than less wealthy individuals. Thus, large governments with high tax levels can be particularly damaging to the incentives to be self-employed for those with high levels of human capital.

Because of the disproportionate negative impact that high levels of taxation have on the expected return of self-employment for individuals with high levels of human capital, it is likely that high taxes and large governments will also disproportionately affect the likelihood that individuals with high levels of human capital will be selfemployed. Thus, there will be a larger difference in the likelihood of self-employment between those with high levels of education and those with moderate levels of education when the government is large verses when it is small.

H8: The positive relationship between having a college education and the likelihood of self-employment will be stronger for individuals in countries with small governments/low taxation levels than individuals in countries with large governments/high taxation levels.

\section{Regulation of Business and Human Capital}

Government regulations can make the process of starting and/or operating a business more time-consuming and costly. Such regulations vary greatly among countries (Brunetti et al., 1997; Djankov et al., 2002; Gwartney et al., 2007). Although the regulations placed on businesses by governments can negatively affect all those who 
are engaged in or considering self-employment, their impact is likely to differ depending on an individual's level of human capital. When individuals have low levels of human capital, they are likely to have difficulty dealing with complex problems (Ucbasaran, Westhead, \& Wright, 2008). Starting or operating a business is likely to be more difficult if business regulations are substantial (van Stel et al., 2007). Thus, individuals with low levels of human capital may not possess the necessary knowledge to start and effectively operate a business in such an environment. Furthermore, they will likely not have sufficient resources to hire accountants and lawyers and, in some cases, pay the necessary bribes to help them through the process of starting a business.

For those with higher levels of human capital, business regulations are likely to be less of a deterrent to starting and operating a business. This is because these individuals are likely to have the knowledge and resources necessary to start and operate business even when business regulations make doing so difficult. Thus, when government regulation of business is substantial, those with lower levels of human capital will disproportionately be less likely to start a new firm and more likely to leave an existing independent business than individuals with high levels of human capital.

H9: The positive relationship between having a college education and the likelihood of self-employment will be stronger for individuals in countries with high levels of business regulation than individuals in countries with low levels of business regulation. 


\subsection{METHODS AND RESULTS}

\section{Sample}

I obtained a sample of individuals from the Global Entrepreneurship Monitor (GEM) survey for the years 2001 to 2006 . The GEM survey is a cross-country data collection project that surveys individuals about their engagement (or lack of engagement) in entrepreneurship (Reynolds, Bygrave, Autio, Cox, \& Hay, 2004). The GEM data contains surveys of individuals from a number of countries (Minniti, Bygrave, \& Autio, 2005). Each year, individuals were selected at random. Hence, the GEM survey is not longitudinal in the strict sense because the same respondents are not followed over time. Instead, it contains cross-sectional data for each year that are pooled together.

The GEM data were collected using both phone and face-to-face interviews. Respondents were selected using either random digit dialing or random selection of geographical clusters (Reynolds et al., 2005). Random digit dialing was used in countries in which a large proportion of adults had a landline phone, and the interview was conducted over the phone. Geographic stratified sampling was used in areas in which landline phones were not owned by a large number of people in the population, and actual interviews were conducted face-to-face. Data were collected from individuals from a number of high-income countries, such as the United States, Sweden, and Ireland, as well as a number of middle-income countries, such as Romania, Brazil, and Turkey (Minniti et al., 2005). Generally, the sample included a minimum of 2,000 individual 
observations for each country for each year it was included in the sample, although there are many more observations for some countries (Reynolds et al., 2005).

The GEM data were collected from a random sample of individuals; the data was not collected from a random sample of known entrepreneurs. Surveyed individuals were asked a number of questions concerning how they perceive entrepreneurship, as well as if they were self-employed or were planning to become self-employed. If they were selfemployed, they were asked some basic question about their business, such as how long they had been in business and the number of people their business employed at the time. Therefore, from this data several measures of entrepreneurship, and several categories of entrepreneurs can be derived: (1) nascent entrepreneurs (those who were trying to start a business at the time of the survey), (2) owner-managers of new firms up to 3.5 years old, and (3) owner-managers of established firms that were more than 3.5 years old. Furthermore, the GEM questionnaire asked respondents whether their entrepreneurship motivated by economic necessity or if it arose to exploit a profitable opportunity; thus measures of necessity- and opportunity-motivated entrepreneurship are available (McMullen et al., 2008). For a more detailed description of the data collection process used in the GEM surveys, see Reynolds et al. (2005).

For the years 2001 through 2006, there are 713,737 individual-level observations. However, only 472,243 observations are used in the analysis, due to missing data. For example, the following question, "Fear of failure would prevent you from starting a business?" was only answered by 540,539 respondents (173,198 cases had missing data). Likewise the question "Have the knowledge, skill, and experience required to start a new 
business?" was only answered by 546,514 respondents (167,223 cases had missing data). Individuals were surveyed from 55 unique countries. Some countries were surveyed every year, while others were surveyed for only select years during the 2001-2006 timespan.

\section{Dependent Variable}

Although several measures of entrepreneurship are available in the GEM dataset, I wish to examine the relationship that institutions have with an individual's choice to engage in self-employment. The dependent variable used in this analysis is whether the individual is self-employed, regardless of the age of the business. The GEM survey measured this by asking individuals if they were owner-manager of a firm. The response is coded as a 1 if the individual was an owner-manager at the time and 0 if the individual was not.

\section{Independent Variables}

Recently, there have been several empirical papers examining the relationship between institutions and the level of entrepreneurship in an economy (McMullen et al., 2008; Nyström, 2008; Sobel, 2008). Measuring institutions is a difficult proposition because it often involves developing numerical measures for concepts such as the strength of property rights and the level of business regulation, which are not naturally represented by numerical values. Therefore, counts, such as the average number of days it takes to get a business license, are sometimes used, as well as indices which use some sort of scoring mechanism, such as in the economic freedom indices (Ayal \& Karras, 
1998; Dawson, 1998). Several indices are commonly used to measure economic freedom, including the Economic Freedom of the World index and the Index of Economic Freedom. I use both of these indices in the analysis. Both indices have an aggregate score that measures economic freedom, as well as individual components that measure different aspects of economic freedom. Each component in both indices is typically derived from multiple measures.

\section{Economic Freedom of the World}

The Economic Freedom of the World index is published by the Fraser Institute (Gwartney et al., 2007). Instead of scoring states/provinces on their level of economic freedom, this index scores individual countries. This index is made up of 23 measures aggregated into five components: (1) size of government, (2) legal structure and property rights, (3) access to sound money, (4) freedom to trade internationally, and (5) regulation of credit, labor and business. Table 2.1 displays the measures making up the five components. 
Table 2.1: Economic Freedom of the World Index Components

\begin{tabular}{|c|c|}
\hline Components & Measures \\
\hline \multirow{4}{*}{$\begin{array}{l}\text { 1. Size of Government: } \\
\text { Expenditures, Taxes and } \\
\text { Enterprise }\end{array}$} & 1A: General Government Spending as a Percentage of Total Consumption \\
\hline & 1B: Transfers and Subsidies as a Percentage of GDP \\
\hline & 1C: Government Enterprises and Investment \\
\hline & $\begin{array}{l}\text { 1D: Top Marginal Tax Rate } \\
\text { i: Top Marginal Income Tax Rate } \\
\text { ii: Top Marginal Income and Payroll Tax Rate }\end{array}$ \\
\hline \multirow{7}{*}{$\begin{array}{l}\text { 2. Legal Structure and } \\
\text { Security of Property Rights }\end{array}$} & 2A: Judicial Independence (GCR) \\
\hline & 2B: Impartial Courts (GCR) \\
\hline & 2C: Protection of Property Rights (GCR) \\
\hline & 2D: Military Interference in Rule of Law and Political Process (ICRG) \\
\hline & 2E: Integrity of the Legal System (ICRG) \\
\hline & 2F: Legal Enforcement of Contracts (DB) \\
\hline & 2G: Regulatory Restrictions on the Sale of Real Property (DB) \\
\hline \multirow{4}{*}{ 3. Access to Sound Money } & 3A: Money Growth \\
\hline & 3B: Standard Deviation of Inflation \\
\hline & 3C: Inflation Most Recent Year \\
\hline & 3D: Freedom to Own Foreign Currency Bank Accounts \\
\hline \multirow[t]{5}{*}{$\begin{array}{l}\text { 4. Freedom to Trade } \\
\text { Internationally }\end{array}$} & $\begin{array}{l}\text { 4A: Taxes on International Trade } \\
\text { i: Revenue from Trade Taxes } \\
\text { ii: Mean Tariff Rate } \\
\text { iii: Standard Deviation of Tariff Rates }\end{array}$ \\
\hline & $\begin{array}{l}\text { 4B: Regulatory Trade Barriers } \\
\text { i: Non-tariff Trade Barriers (GCR) } \\
\text { ii: Compliance Cost of Importing and Exporting (DB) }\end{array}$ \\
\hline & 4C: Size of Trade Sector Relative to Expected \\
\hline & 4D: Black-Market Exchange Rates \\
\hline & $\begin{array}{l}\text { 4E: International Capital Market Controls } \\
\text { i: Foreign Ownership/Investment Restrictions (GCR) } \\
\text { ii: Capital Controls }\end{array}$ \\
\hline \multirow[t]{3}{*}{$\begin{array}{l}\text { 5. Regulations of Credit, } \\
\text { Labor and Business }\end{array}$} & $\begin{array}{l}\text { 5A. Credit Market Regulations } \\
\text { i: Ownership of Banks } \\
\text { ii: Foreign Bank Competition } \\
\text { iii: Private Sector Credit } \\
\text { iv: Interest Rate Controls/Negative Real Interest Rates }\end{array}$ \\
\hline & $\begin{array}{l}\text { 5B: Labor Market Regulations } \\
\text { i: Minimum Wage (DB) } \\
\text { ii: Hiring and Firing Regulations (GCR) } \\
\text { iii: Centralized Collective Bargaining (GCR) } \\
\text { iv: Mandated Cost of Hiring (DB) } \\
\text { v: Mandated Cost of Worker Dismissal (DB) } \\
\text { vi: Conscription }\end{array}$ \\
\hline & $\begin{array}{l}\text { 5C: Business Regulations } \\
\text { i: Price Controls } \\
\text { ii: Administrative Requirements (GCR) } \\
\text { iii: Bureaucracy Costs (GCR) } \\
\text { iv: Starting a Business (DB) } \\
\text { v: Extra Payments/Bribes (GCR) } \\
\text { vi: Licensing Restrictions (DB) } \\
\text { vii: Cost of Tax Compliance (DB) }\end{array}$ \\
\hline
\end{tabular}




\section{Index of Economic Freedom}

The Index of Economic Freedom was developed by the Heritage Foundation (2005). This index measures economic freedom at the country level of analysis, and higher values indicate more freedom. This index is made up of a number of measures making up 10 components: (1) business freedom, (2) trade freedom, (3) fiscal freedom, (4) government size, (5) monetary freedom, (6) investment freedom, (7) financial freedom, (8) property rights, (9) freedom from corruption, and (10) labor freedom. Table

2.2 displays the measures making up these 10 components. 
Table 2.2: Index of Economic Freedom Components

\begin{tabular}{|c|c|}
\hline Components & Measures \\
\hline \multirow[t]{10}{*}{ 1. Business Freedom } & Starting a Business- procedures (number)- from the Doing Business survey (DB) \\
\hline & Starting a Business- time (days) (DB) \\
\hline & Starting a Business- cost ( $\%$ of per capita income) (DB) \\
\hline & Starting a Business- minimum capital (\% of income per capita) (DB) \\
\hline & Obtaining a License-procedures (number) (DB) \\
\hline & Obtaining a License- time (days) (DB) \\
\hline & Obtaining a License- cost ( $\%$ of income per capita) (DB) \\
\hline & Closing a Business- time (years) (DB) \\
\hline & Closing a Business- cost (\% of estate) (DB) \\
\hline & Closing a Business- recovery rate (cents on the dollar) (DB) \\
\hline \multirow[t]{2}{*}{ 2. Trade Freedom } & Trade-Weighted Average Tariff Rate \\
\hline & Non-Tariff Barriers (qualitative penalty) \\
\hline \multirow[t]{3}{*}{ 3. Fiscal Freedom } & Top Tax Rate on Individual Income \\
\hline & Top Tax Rate on Corporate Income \\
\hline & Total Tax Revenue as a Percentage of GDP \\
\hline 4. Government Size & Government Expenditures: $\left(100-.03 *(\text { Expenditures/GDP })^{2}\right)$ \\
\hline \multirow{2}{*}{ 5. Monetary Freedom } & Weighted Average Inflation for Past Three Years \\
\hline & Price Controls (qualitative penalty) \\
\hline 6. Investment Freedom & Restrictions on Foreign Investment (qualitative) \\
\hline 7. Financial Freedom & Banking Security and Independence From Government (qualitative) \\
\hline 8. Property Rights & Certainty of the Legal Protection of Property (qualitative) \\
\hline $\begin{array}{l}\text { 9. Freedom From } \\
\text { Corruption }\end{array}$ & Corruptions Perceptions Index $(\mathrm{CPI})^{*}(10)$ \\
\hline \multirow{6}{*}{ 10. Labor Freedom } & Ratio of Minimum Wage to Average Value Added Per Worker (DB) \\
\hline & Hindrance to Hiring Additional Workers (DB) \\
\hline & Rigidity of Hours (DB) \\
\hline & Difficulty of Firing Redundant Employees (DB) \\
\hline & Legally Mandated Notice Period (DB) \\
\hline & Mandatory Severance Pay (DB) \\
\hline
\end{tabular}

The components from the IEF and EFW index are measures of very similar concepts. Most studies using economic freedom indices make use of components from one of these indices. However, in this essay, I will perform separate analyses, one using measures from the IEF and another using measures from the EFW. Therefore, the robustness of the relationship between the institutional measures and self-employment can be tested. If the relationship is robust between one of the institutional measures and 
self-employment, then it should not be significant whether the component is taken from the IEF or EFW index.

One issue in using these two indices in separate analyses is that they need to be modified so that the individual index components used in the analysis are approximately the same between the two indices and so that they both measure the hypothesized constructs. Although the various components of these indices measure similar concepts, these components do not match up perfectly and thus limit the degree to which they are comparable. For example, in the Economic Freedom of the World (EFW) index, one component is Size of Government: Expenditures, Taxes, and Enterprises. In the Index of Economic Freedom (IEF), there is, one component called Government Size and another called Fiscal Freedom (representing the overall tax burden). Therefore, to compare the measures from the different indices, some of the components need to be modified in order for them to be measuring approximately the same construct. Due to this, the 10 components of the IEF are combined to make them directly comparable to those in the EFW index. The combined IEF components will be referred to as the modified Index of Economic Freedom components. Table 2.3 displays how the IEF components are combined to create the modified IEF components and how these new components match with the components of the EFW index (as well as the hypothesized constructs). The modified IEF components are constructed by simply averaging the scores of the components from which they are made. The correlations between the components of the EFW index and the modified IEF can be seen in Table 2.4. The high correlation between the EFW index components and the modified IEF components provides evidence of 
convergent validity between these measures, indicating that they are measuring the same underlying construct. All of the correlations were significantly different from zero $(p<$ $.01)$

Table 2.3: Institution Measures Modified

\begin{tabular}{|l|l|}
\hline Components of EFW index & $\begin{array}{l}\text { Corresponding Components } \\
\text { in the IEF }\end{array}$ \\
\hline $\begin{array}{l}\text { 1. Size of Government: } \\
\text { Expenditures, Taxes and } \\
\text { Enterprise }\end{array}$ & $\begin{array}{l}\text { Government Size } \\
\text { Fiscal Freedom }\end{array}$ \\
\hline $\begin{array}{l}\text { 2. Legal Structure and } \\
\text { Security of Property Rights }\end{array}$ & $\begin{array}{l}\text { Property Rights } \\
\text { Freedom From Corruption }\end{array}$ \\
\hline 3. Access to Sound Money & Monetary Freedom \\
\hline $\begin{array}{l}\text { 4. Freedom to Trade } \\
\text { Internationally }\end{array}$ & $\begin{array}{l}\text { Trade Freedom } \\
\text { Investment Freedom }\end{array}$ \\
\hline $\begin{array}{l}\text { 5. Regulations of Credit, } \\
\text { Labor and Business }\end{array}$ & $\begin{array}{l}\text { Business Freedom } \\
\text { Labor Freedom } \\
\text { Financial Freedom }\end{array}$ \\
\hline
\end{tabular}

Table 2.4: Correlation between EFW Components and Modified IEF Components

\begin{tabular}{|l|c|c|c|c|c|}
\hline & \multicolumn{5}{|c|}{ Corresponding Modified IEF Components } \\
\hline EFW Components & 1. & 2. & 3. & 4. & 5. \\
\hline $\begin{array}{l}\text { 1. Size of Government: } \\
\text { Expenditures, Taxes } \\
\text { and Enterprise }\end{array}$ & .758 & & & & \\
\hline $\begin{array}{l}\text { 2. Legal Structure and } \\
\text { Security of Property } \\
\text { Rights }\end{array}$ & & .910 & & & \\
\hline $\begin{array}{l}\text { 3. Access to Sound } \\
\text { Money }\end{array}$ & & & .692 & & \\
\hline $\begin{array}{l}\text { 4. Freedom to Trade } \\
\text { Internationally }\end{array}$ & & & & .673 & \\
\hline $\begin{array}{l}\text { 5. Regulations of } \\
\text { Credit, Labor and } \\
\text { Business }\end{array}$ & & & & & .734 \\
\hline
\end{tabular}

Correlations are from the countries included in the GEM survey for years 2001-2006. All correlations are significant at $p<.01 . \mathrm{n}=208$. 


\section{Control Variables}

\section{Country Level}

An economy's wealth influences the level of self-employment. Generally, in poorer countries, people enter self-employment out of lack of other options (McMullen et al., 2008). More opportunities for self-employment may exist because there is a lack of capital-intensive firms that rely on economies of scale. Conversely, in wealthier, more developed countries, people do not need to enter self-employment to survive because there are other employment options. Many studies have found a negative relationship between gross domestic product and the level of entrepreneurship in a country (Noorderhaven et al., 2004; Torrini, 2005; Wong, Ho, \& Autio, 2005). In this analysis, I use a measure of country-level gross domestic product per capita corrected for purchasing power parity (PPP) from the World Bank World Development Indicators for each year (The World Bank, 2010).

Similarly, unemployment rates may influence self-employment (Blanchflower, 2000; Tervo, 2006). High unemployment may be a proxy for a poorly performing economy, thus making self-employment a less attractive option for individuals. On the other hand, high unemployment may lead to individuals entering self-employment due to a lack of other employment options. Country unemployment rates are included for all years (International Labour Organization, 2010). 


\section{Individual Level}

Several individual-level control variables are likely to have an impact on the likelihood that an individual is self-employed. One variable that has been predictive of this is gender. Research has documented that males are more likely to be self-employed than females (Carter \& Brush, 2004; Lindh \& Ohlsson, 1996; Reynolds, 2004).

Explanations for gender differences in the likelihood that an individual is self-employed include differences in human and financial capital between males and females, differences in intentions, as well as differences in risk propensity (Carter \& Brush, 2004). Gender is a dichotomous variable coded for the analysis with $1=$ male and $0=$ female.

Past research also finds a relationship between an individual's age and his or her propensity to engage in entrepreneurship, with the probability of being self-employed usually increasing as a person ages (Blanchflower, 2000; Evans \& Leighton, 1989; Lindh \& Ohlsson, 1996). There are several possible explanations for this. As people age, their level of human capital often increases, possibly making them more likely to discover opportunities as they get older. Furthermore, many people's preferences change as they get older, and older people may get more psychic income from self-employment than those that are younger. Age is included as a control variable. Likewise, I created an age

squared control variable in order to capture a possible nonlinear relationship between age and self-employment, since both the very young and very old may be less likely to be self-employed.

An individual's level of human capital influences the likelihood that they will engage in entrepreneurship as well (Bates, 1995; Davidsson \& Honig, 2003). One 
common measure of human capital is the level of education that an individual has obtained. Some evidence has shown that the relationship between education and selfemployment is non-linear, with the lowest and highest educated more likely to be selfemployed than those with an average level of education (Blanchflower, 2000). Education is measured as an ordinal measure in the GEM with the following categories: (1) no secondary schooling, (2) some secondary schooling, (3) secondary school degree, (4) post-secondary degree, and (5) graduate experience. In order to control for this and examine the moderation hypotheses, I recode these into two categories: no college education and college education. Those with no secondary schooling, some secondary schooling, or a secondary school degree are considered to have no college education, while those with a post-secondary degree or graduate experience are considered to have a college degree.

Although an individual's level of education may certainly influence the probability that he or she is self-employed, this is a general measure of human capital. In addition to formal schooling, human capital is developed by an individual through work experience and non-formal sources of training (Davidsson \& Honig, 2003), and some of the human capital developed through these avenues may be particularly useful in selfemployment. As an indicator of human capital specific to self-employment, I included the response from an item asking the respondent if he or she "has the knowledge, skill, and experience required to start a new business?" Yes responses were coded as 1, no responses as 0 . 
One possible determinant to an individual being self-employed is whether he or she approaches self-employment with a prevention focus. If an individual is preventionfocused about entrepreneurship, he or she will worry about the possibility of failure and will act in a way that minimizes this possibility, even if he or she risks possible gains. A substantial number of new firms fail (Mata \& Portugal, 1994; Phillips \& Kirchhoff, 1989); therefore, given their desire for safety and security, individuals who approach entrepreneurship with a prevention focus are likely to find becoming self-employed too risky. I control for individual's prevention focus by including the following item: "Fear of failure would prevent you from starting a business?" Yes responses, indicating a prevention focus, were coded as 1; no responses, indicating a promotion focus, were coded as 0 .

Dummy variables are entered for each year (except 2001). This allows the intercept to vary across years (Wooldridge, 2003).

\section{Analysis}

The GEM survey data used in this analysis are individual-level responses, which I combine with country-level measures of institutions, unemployment, and economic development. Thus, the GEM data contains a number of individual responses nested within various countries. To perform this analysis, random coefficient multilevel modeling is performed. Much of the past research concerning the relationship between institutions and entrepreneurship has involved performing regressions using country-level measures of institutions to predict country-level rates of self-employment or nascent activity (Bjornskov \& Foss, 2008; McMullen et al., 2008; Sobel et al., 2007). In contrast, 
a random coefficient multilevel modeling approach can be used to predict the probability that any individual will engage in self-employment, using individual-level as well as country-level characteristics. This allows for individual-level control variables, such as individuals' beliefs and perceptions about themselves, educational level, and gender to be added to the model (Luke, 2004). Furthermore, multilevel modeling allows for the testing of cross-level interactions. Although in a purely country-level analysis individuallevel variables can be aggregated to the country-level, such aggregation may lead to inflated relationships and misinterpretation if interpreted at the individual level (Luke, 2004; Tabachnick \& Fidell, 2006).

The analysis is performed using the lmer and glmmPQL packages in R. Specifically, I used the commercial 64-bit version of R known as Revolution R Enterprise developed by Revolution Analytics. While a number of packages, such as HLM 6 and will perform this type of analysis, the 64-bit version of Revolution $\mathrm{R}$ allows a multi-level analysis to be performed even with a substantial number of independent variables and an extremely large sample size. Using multi-level modeling software, the researcher can model randomly-varying intercepts and slopes, and with the appropriate link function, can model various types of outcome variables. In all of the hypotheses, the dependent variable is dichotomous; therefore, a logit link function is used for all the regressions. To test the developed hypothesis, I followed a model-building process recommended by Raudenbush and Bryk (2002). When the random coefficient model is estimated, it is tested to see what random effects are significant and should be kept random in the final 
model. Finally, a model containing the variables of interest is estimated so that the developed hypotheses can be tested.

Individual-level dichotomous variables are left uncentered, while continuous variables (such as age) are grand-mean centered. The use of grand-mean centering is recommended when the influence of level-2 variables on the dependent variables are of primary interest (Enders \& Tofighi, 2007).

The estimation equations for the hypothesized model are presented in the following paragraphs, beginning with the level-1 equation and then a series of level-2 equations.

(1) $Y_{i j}=$ logistic $_{\left(\beta_{0 j}\right.}+\beta_{1}$ Gender $_{i}+\beta_{2}$ Age $_{i}+\beta_{3}$ AgeSquared $_{i}+\beta_{4}$ EntSkills $_{i}+\beta_{5 j}$ College $_{i}$ $+\beta_{6 \mathrm{j}}$ PreFocus $\left._{\mathrm{i}}\right)$

Equation 1 is known as the level-1 equation in a multilevel model (Tabachnick \& Fidell, 2006). In equation (1), $\mathrm{Y}_{\mathrm{ij}}$ is the probability that individual $i$ from country $j$ is self-employed. $\beta_{0 \mathrm{j}}$ represents the intercept term for country $j$, and the intercept term is allowed to vary by country. In the hypothesized mode several control variables are individual-level variables, including gender, age, college education, entrepreneurial skills, and prevention focus. The terms $\beta_{1}$ through $\beta_{4}$ represent the slopes for individuallevel variables with coefficients that do not vary by country. Only the slopes for college $\left(\beta_{5 \mathrm{j}}\right)$ and prevention focus $\left(\beta_{6 \mathrm{j}}\right)$ are allowed to vary by country.

$$
\beta_{0 \mathrm{j}}=\gamma_{00}+\gamma_{01} \text { GovSize }_{\mathrm{j}}+\gamma_{02} \text { BusinessRegulations }_{\mathrm{j}}+\gamma_{03} \text { TradeFreedom }_{\mathrm{j}}+
$$

$\gamma_{04}$ PropertyRights $_{\mathrm{j}}+\gamma_{05}$ SoundMoney $_{\mathrm{j}}+\gamma_{06}$ GDPPerCapita $_{\mathrm{j}}+\gamma_{07}$ UnemploymentRate $_{\mathrm{j}}+u_{0 \mathrm{j}}$ 
In equation $1, \beta_{0 \mathrm{j}}$ represents the intercept term which is allowed to vary across countries. Equation 2, the level-2 equation for the intercept, shows how $\beta_{0 \mathrm{j}}$ is determined. Country characteristics for country $j$ are used to predict $\beta_{0 \mathrm{j}}$. The terms $\gamma_{01}$ through $\gamma_{07}$ represent the slope coefficients for these variables (Tabachnick \& Fidell, 2006). $u_{0 \mathrm{j}}$ represents the error term for the intercept, or the variation of $\beta_{0 \mathrm{j}}$ from its mean that is not explained by the variables in the equation.

$$
\beta_{5 \mathrm{j}}=\gamma_{50}+\gamma_{51} \text { GovSize }_{\mathrm{j}}+\gamma_{52} \text { BusinessRegulations }_{\mathrm{j}}+u_{5 \mathrm{j}}
$$

Equation 3 is the level-2 equation that shows how the random slope coefficient $\beta_{5 \mathrm{j}}$, is determined. $\beta_{5 \mathrm{j}}$ is the slope coefficient for the level-1 dummy variable for college education. Government size/taxation levels and the level of business regulations are used

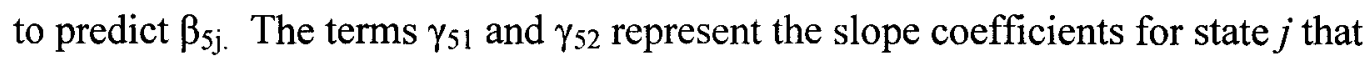
displays the relationship between their associated level- 2 predictors and $\beta_{5 \mathrm{j}}$. $u_{5 \mathrm{j}}$ represents the variance in $\beta_{5 j}$ from its mean that remains unexplained by government size and the level of business regulations.

$$
\beta_{6 j}=\gamma_{60}+\gamma_{61} \text { PropertyRights }_{j}+\gamma_{62} \text { SoundMoney }_{j}+u_{6 j}
$$

Equation 4 is the level-2 equation that shows how the random slope coefficient $\beta_{6 \mathrm{j}}$, is determined. $\beta_{6 \mathrm{j}}$ is the slope coefficient for the level-1 dummy variable representing prevention focus. The level of property rights and soundness of money in state $j$ are used to predict $\beta_{6 j}$. These include the overall tax burden as well as the level of government regulations. The terms $\gamma_{61}$ and $\gamma_{62}$ represent the slope coefficients for these variables. $u_{6 \mathrm{j}}$ 
represents the variance in $\beta_{6 \mathrm{j}}$ from its mean that remains unexplained by property rights and the soundness of money.

For all other level-1 variables, the slope coefficients will be fixed (will not be allowed to vary by country).

\section{Results}

The means and standard deviations of all the variables can be seen Table 2.5. The correlation matrix can be seen in Table 2.6. Due to the large sample size, many of the correlations are significant at $.001(* * *), .01(* *)$ or $.05(*)$. 
Table 2.5: Descriptive Statistics

\begin{tabular}{|l|c|c|c|}
\hline Variable & Mean & Standard Deviation & $\mathbf{N}$ \\
\hline Owner/Manager & .1462 & .3533 & 473,243 \\
\hline Gender & .4841 & .4998 & 473,243 \\
\hline Skill & .4547 & .4979 & 473,243 \\
\hline Prevention Focus & .3469 & .4760 & 473,243 \\
\hline Age & 42.96 & 15.82 & 473,243 \\
\hline Age Squared & 2,096 & 1,490 & 473,243 \\
\hline College Education & .3342 & .4717 & 473,243 \\
\hline GDP per Capita PPP & 21,620 & 9,945 & 194 \\
\hline Unemployment Rate & 7.79 & 4.97 & 194 \\
\hline Government Size (EFW) & 4.21 & 1.50 & 194 \\
\hline $\begin{array}{l}\text { Business Regulations } \\
\text { (EFW) }\end{array}$ & 3.46 & .926 & 194 \\
\hline Trade Freedom (EFW) & 7.51 & .805 & 194 \\
\hline Property Rights (EFW) & 7.20 & 1.69 & 194 \\
\hline Sound Money (EFW) & 8.86 & 1.08 & 194 \\
\hline Government Size (IEF) & 43.12 & 19.17 & 194 \\
\hline $\begin{array}{l}\text { Business Regulations } \\
\text { (IEF) }\end{array}$ & 30.63 & 12.93 & 194 \\
\hline Trade Freedom (IEF) & 70.84 & 11.39 & 194 \\
\hline Property Rights (IEF) & 67.97 & 21.65 & 194 \\
\hline Sound Money (IEF) & 82.68 & 7.02 & 194 \\
\hline $\begin{array}{l}\text { Startup and Operating } \\
\text { Regulations (EFW) }\end{array}$ & 3.83 & 1.25 & 194 \\
\hline Labor Regulations (EFW) & 4.55 & 1.37 & 194 \\
\hline Credit Regulations (EFW) & 1.71 & 1.10 & 194 \\
\hline & & & \\
\hline
\end{tabular}




\section{Table 2.6: Correlations}

\begin{tabular}{|c|c|c|c|c|c|c|c|c|c|c|c|c|c|c|c|c|c|c|c|}
\hline \multirow{2}{*}{\begin{tabular}{|r|}
\multicolumn{1}{|c|}{ Variable } \\
(1) Self Employment
\end{tabular}} & 1 & 2 & 3 & 4 & 5 & 6 & 7 & 8 & 9 & 10 & 11 & 12 & 13 & 14 & 15 & 16 & 17 & 18 & 19 \\
\hline & & & & & & & & & & & & & & & & & & & \\
\hline (2) Gender & $.110^{* * *}$ & & & & & & & & & & & & & & & & & & \\
\hline (3) Skill & $.302^{* * *}$ & $173^{* * *}$ & & & & & & & & & & & & & & & & & \\
\hline (4) Prevention Focus & $-.090 * * *$ & $-.070^{* * *}$ & $-133 * * *$ & 1 & & & & & & & & & & & & & & & \\
\hline (5) Age & $.009^{* * *}$ & $-.033^{* * * *}$ & $-.035^{* * *}$ & $-.040^{* * *}$ & i & & & & & & & & & & & & & & \\
\hline (6) Age squared & $-.017^{* * *}$ & $-.030^{* * *}$ & $-.058^{* * *}$ & $-.049^{* * *}$ & $978^{* * *}$ & 1 & & & & & & & & & & & & & \\
\hline (7) College & $.043^{* * *}$ & $.022^{* * *}$ & $.118^{* * *}$ & $\mid-041^{* * *}$ & $-.048 * * *$ & $-.061^{* * *}$ & & & & & & & & & & & & & \\
\hline (8) GDP per Capita PPP & $-.062^{* * *}$ & $-.013^{* * *}$ & $-.052 * * *$ & $-.011^{* * *}$ & $152 * * *$ & $.152 * * *$ & $.149^{* * * *}$ & & & & & & & & & & & & \\
\hline (9) Unemployment Rate & $-.022 * * *$ & $.016^{* * *}$ & $.010^{* * *}$ & $.023^{* * *}$ & $-.074 * * *$ & $-.068^{* * * *}$ & $-.101^{* * *}$ & $-.470^{* * *}$ & & & & & & & & & & & \\
\hline $\begin{array}{l}\text { (10) Government Size/Taxation } \\
\text { (EFW) }\end{array}$ & $-073 * * *$ & $.003^{* * *}$ & $-096 * * *$ & $-.004^{* *}$ & $.023^{* * *}$ & $.028 * * *$ & $-.014^{* * *}$ & $.185^{* * * *}$ & $-090^{* * *}$ & 1 & & & & & & & & & \\
\hline (11) Property Rights (EFW) & $-.050 * * *$ & $-.021 * * *$ & $-061^{* * *}$ & $-.020^{* * *}$ & $139 * * *$ & $142^{* * *}$ & $.118^{* * *}$ & $803 * * *$ & $-.432 * * *$ & $.234^{* * *}$ & & & & & & & & & \\
\hline (12) Sound Money (EFW) & $-.061 * * *$ & $-.009 * * *$ & $-.031 * * *$ & \begin{tabular}{|l|}
$014^{* * * *}$ \\
\end{tabular} & $088^{* * * *}$ & $.086 * * *$ & $.076^{* * * *}$ & $702 * * *$ & $\mid-315 * * *$ & $.220 * *$ & $591^{* * *}$ & 1 & & & & & & & \\
\hline (13) Trade Freedom (EFW) & $-.084 * * *$ & $-.016^{* * *}$ & $.081 * *$ & $.004 *$ & $.077 * * *$ & $.083^{* * *}$ & $.040^{* * *}$ & $418^{* * *}$ & $-.293 * * *$ & $158^{* * * *}$ & $544^{* * *}$ & $483^{* * *}$ & 1 & & & & & & \\
\hline $\begin{array}{l}\text { (14) Business Regulation } \\
\text { (EFW) }\end{array}$ & $.011^{* * *}$ & $.016^{* * *}$ & $-.024^{* * *}$ & $.036^{* * *}$ & $-.082 * * *$ & $-.079^{* * *}$ & $-.154 * * *$ & $-.554^{* * *}$ & $.376^{* * *}$ & $.284^{* * *}$ & $-.571^{* * *}$ & $-.352^{* * *}$ & $-.274^{* * *}$ & & & & & & \\
\hline $\begin{array}{l}\text { (15) Government Size/Taxation } \\
\text { (IEF) }\end{array}$ & $.082^{* * *}$ & .000 & $.062 * * *$ & $.014^{* * *}$ & $.058^{* * * *}$ & $.057 * * *$ & $.032^{* * *}$ & $.504^{* * *}$ & $-.155^{* * *}$ & $.776^{* * *}$ & $.451^{* * *}$ & $.521^{* * *}$ & $.217^{* * *}$ & $-.033^{* * *}$ & & & & & \\
\hline (16) Property Rights (IEF) & $-.066^{* * * *}$ & $.015^{* * *}$ & $-.050^{* * *}$ & $-.005^{* * * *}$ & $.130^{* * * *}$ & $.131^{* * *}$ & $.115^{* * * *}$ & $870^{* * *}$ & $-.463^{* * * *}$ & $.177^{* * *}$ & $898^{* * *}$ & $679^{* * *}$ & $.580^{* * * *}$ & $-.607 * * *$ & $.473 * * *$ & 14 & & & \\
\hline (17) Sound Money (IEF) & $-.037^{* * *}$ & $-.008^{* * *}$ & $-.041^{* * *}$ & $.021^{* * * *}$ & $.084^{* * * *}$ & $.086^{* * *}$ & $.091 * * *$ & $545^{* * *}$ & $\mid-255^{* * * *}$ & $.060^{* * *}$ & $.546^{* * *}$ & $604^{* * *}$ & $.404^{* * * *}$ & $-.337 * * *$ & $.251^{* * *}$ & $.609 * * *$ & & & \\
\hline (18) Trade Freedom (IEF) & $-.079 * * *$ & $-.016^{* * *}$ & $-.040^{* * *}$ & $029^{* * *}$ & $099 * * *$ & $.103^{* * *}$ & $.048^{* * *}$ & $.666^{* * *}$ & $-203^{* * *}$ & $.146^{* * * *}$ & $.641^{* * *}$ & $675^{* * *}$ & $.647 * * *$ & $-.386 * * *$ & $444^{* * *}$ & $.742^{* * *}$ & $.481^{* * *}$ & & \\
\hline (19) Business Regulation (IEF) & $.035^{* * *}$ & $.019^{* * * *}$ & $-.012^{* * *}$ & $.036 * * *$ & $-.097 * * *$ & $-.100^{* * * *}$ & $-140^{* * *}$ & $-.615^{* * *}$ & $408^{* * * *}$ & $.163^{* * *}$ & $-.599^{* * *}$ & $-.492^{* * *}$ & $-.446^{* * *}$ & $.802^{* * *}$ & $-144^{* * * *}$ & $-689^{* * *}$ & $-.404 * * *$ & $.544^{* * *}$ & \\
\hline
\end{tabular}


The need for using random coefficient modeling ( $\mathrm{RCM})$ can be assessed by calculating interclass correlations (ICCs). Intraclass correlations are calculated to see how variance in the dependent variable can be explained by the different levels of analysis in the proposed multilevel model. It represents the correlation between two randomly chosen level-1 units within the same level-2 unit cluster. To obtain the needed information to calculate an ICC, I first run an unconditional (null) model in which the variability in the dependent variable is partitioned to the different levels. With a continuous dependent variable, the ICC is calculated by dividing the variance in the dependent variable at level-2 by the total variance of the dependent variable (which is the sum of the level-2 and level-1 variances). However, with a binary outcome the total variance of the dependent variable cannot really be estimated. However, Hox (2010) recommends calculating a pseudo-ICC by dividing the variance at level- 2 by the sum of the level-2 variance and the variance of the logistic distribution. 3.29 is the variance of a logistic distribution with a scale factor of 1 (Hox, 2010). I calculate the ICC using this method. The intraclass correlation can be seen in Table 2.7. I obtain these by running the lmer procedure in Revolution $\mathrm{R}$. The intraclass correlation shows how the variability in the dependent variable is partitioned into the two levels: countries and individuals. The ICC of 0.1156 indicates that $11.56 \%$ of the variance in the likelihood of being selfemployed is due to country differences. This correlation is substantial enough that failure to account for this clustering could inflate the standard errors of the parameter estimates (Kreft \& De Leeuw, 1998), indicating that random coefficient multilevel modeling is an appropriate analysis technique in this circumstance. 
Table 2.7 Intraclass Correlation

\begin{tabular}{|l|c|}
\hline Country Variance & .4294 \\
\hline Variance of the Logistic Distribution & 3.2865 \\
\hline Intraclass Correlation & .1156 \\
\hline
\end{tabular}

The next step is to run the random coefficients model. In the random coefficients model, both the intercept and the level-1 slope coefficients that are predicted to vary are allowed to vary based upon country. This estimation is performed so that these models can be compared with the random slope model, to see if the additional random slopes substantially increase model fit. I have hypothesized that the slope coefficient for both college education (high human capital) and fear prevention focus will vary based upon country.

To determine which model has the best fit, I examine the AIC and BIC indices. Akaike's Information Criterion (AIC) is a general fit index that can be used to compare non-nested models (Hox, 2010). Bayesian Information Criterion (BIC) is a similar index used to assess model fit, but the BIC tends to place more of a penalty on complex models than the AIC. When comparing models, the model with the lower AIC and BIC is preferred. Both measures become smaller as the deviance of the model goes down, as well as when the number of parameters in the model goes down. BIC is calculated using the number of individual observations as the sample size (instead of the number of countries). In Table 2.8, the AIC and BIC for three models are displayed: the null model (random country intercept only); a model with a random intercept and prevention focus 
slope; and a model with a random intercept, prevention focus, and college education slope.

Table 2.8: Random Effects \& Model Fit

\begin{tabular}{|l|l|l|l|l|l|}
\hline Model & Deviance & AIC & BIC & $\begin{array}{l}\text { AIC } \\
\text { Difference }\end{array}$ & $\begin{array}{l}\text { BIC } \\
\text { Difference }\end{array}$ \\
\hline $\begin{array}{l}\text { Null Model (Random } \\
\text { Intercept) }\end{array}$ & 490,488 & 490,492 & 490,515 & & \\
\hline $\begin{array}{l}\text { Random Intercept \& } \\
\text { Prevention Focus } \\
\text { Slope }\end{array}$ & 427,983 & 427,991 & 428,036 & 62,501 & 62,479 \\
\hline $\begin{array}{l}\text { Random Intercept, } \\
\text { Prevention Focus \& } \\
\text { College Slope }\end{array}$ & 406,731 & 406,745 & 406,823 & 21,246 & 21,213 \\
\hline
\end{tabular}

As can be seen in Table 2.8, adding the prevention focus slope to the model improves fit substantially, according to both AIC and BIC measures of fit. Likewise, adding a random slope for college education improves fit substantially as well. However, these substantial differences seem likely due to the extremely large sample size, and thus should be interpreted with caution.

To examine the hypothesized fixed effects, I run the analysis on the several models using the glmmPQL procedure from the MASS package in $\mathrm{R}$. This procedure is similar to the lmer procedure used to examine the null and random effects models but is capable of better estimating more complex models. The lmer procedure had difficulty converging with the more complex models. The disadvantage to using the glmmPQL procedure is that it works somewhat different mathematically, and deviance scores, which are often used to assess model fit in multi-level models are not provided. Thus, the 
discussion of these models will focus on the significance of the hypothesized variables instead of model fit.

The first model includes only a random intercept and control variables. I then estimate a direct effects model containing all of the hypothesized and control variables. I estimate separate models using the Economic Freedom of the World (Gwartney et al., 2007) index and the modified Index of Economic Freedom (Heritage Foundation, 2005) as the institutional variable measures. The last model contains all control and hypothesized variables, as well as interaction terms. Again, I estimate separate models using the EFW index and the modified IEF.

The results for the control model can be seen in Table 2.9. Many of the individual-level control variables are significant predictors of the whether an individual is engaging in self-employment. These include gender $(0.4153 ; p<.0001)$, entrepreneurial skills $(1.7237 ; \mathrm{p}<.0001)$, prevention focus $(-0.3636 ; p<.0001)$, age $(0.1462 ; p<$ $.0001)$, age squared $(-0.0015 ; p<.0001)$. Surprisingly, having a college education $(0.0168 ; p=.0998)$ was not a statistically significant predictor of self-employment. It is important to remember, given the sample size as well as the fact that the control variables included are ones that have been found to significant predictors of self-employment in the past, it is to be expected that many of the individual-level variables would be statistically significant. At the country-level, gross domestic product statistically significantly predicted self-employment $(-0.017 ; p=.0005)$ while unemployment rates did not ($0.0064 ; p=.2429)$. 
Table 2.9: Control Model

\begin{tabular}{|l|c|c|c|c|}
\hline Model 1 & Coefficient & SE & t-value & $\boldsymbol{p}$-value \\
\hline Variable & -0.0918 & 0.0890 & -1.03 & 0.3023 \\
\hline Intercept & 0.4153 & 0.0095 & 43.52 & $<0.0001$ \\
\hline Gender & 1.7237 & 0.0114 & 150.89 & $<0.0001$ \\
\hline Skill & -0.3636 & 0.0475 & -7.65 & $<0.0001$ \\
\hline Prevention Focus & 0.1462 & .0021 & 70.81 & $<0.0001$ \\
\hline Age & -0.0015 & 0.000023 & -67.35 & $<0.0001$ \\
\hline Age Squared & 0.0168 & 0.0102 & 1.65 & 0.0998 \\
\hline College & -0.017 & 0.005 & -3.50 & 0.0005 \\
\hline $\begin{array}{l}\text { GDP per Capita } \\
\text { (thousands) }\end{array}$ & -0.0064 & 0.0055 & -1.17 & 0.2429 \\
\hline $\begin{array}{l}\text { Unemployment } \\
\text { Rate }\end{array}$ & & & & \\
\hline Year 2002 & 0.1328 & 0.0216 & 6.14 & $<0.0001$ \\
\hline Year 2003 & 0.6473 & 0.0231 & 28.04 & $<0.0001$ \\
\hline Year 2004 & 0.5166 & 0.0230 & 22.50 & $<0.0001$ \\
\hline Year 2005 & 0.6820 & 0.0239 & 28.55 & $<0.0001$ \\
\hline Year 2006 & 0.4897 & 0.0243 & 20.19 & $<0.0001$ \\
\hline
\end{tabular}

Table 2.10 displays Model 2 and Table 2.11 displays Model 3. Model 2 is the direct effects model using institutional measures from the Economic Freedom of World index (Gwartney et al., 2007) while Model 3, uses institutional measures from the Index of Economic Freedom (Heritage Foundation, 2005). Italicized variables are the variables that were added to these models. However, my discussion will focus on the Models $4 \&$ 5. 
Table 2.10: EFW Direct Effects Model

\begin{tabular}{|l|c|c|c|c|}
\hline Model 2 & Coefficient & SE & $\boldsymbol{t}$-value & $\boldsymbol{p}$-value \\
\hline Variable & -0.1910 & 0.1019 & -1.87 & 0.0609 \\
\hline Intercept & 0.4158 & 0.0096 & 43.52 & $<0.0001$ \\
\hline Gender & 1.7229 & 0.0114 & 150.63 & $<0.0001$ \\
\hline Skill & -0.3612 & 0.0470 & -7.68 & $<0.0001$ \\
\hline Prevention Focus & 0.1470 & 0.0021 & 71.0509 & $<0.0001$ \\
\hline Age & -0.0016 & 0.000023 & -67.60 & $<0.0001$ \\
\hline Age Squared & 0.0151 & 0.0102 & 1.48 & 0.1382 \\
\hline College & -0.0248 & 0.0062 & -4.01 & $<0.0001$ \\
\hline $\begin{array}{l}\text { GDP per Capita } \\
\text { (thousands) }\end{array}$ & & & & \\
\hline Unemployment Rate & 0.0067 & 0.0061 & 1.11 & 0.2691 \\
\hline Taxation/Government & 0.1119 & 0.0186 & 6.00 & $<0.0001$ \\
Size & & & & \\
\hline Property Rights & 0.0677 & 0.0202 & 3.35 & 0.0008 \\
\hline Sound Money & 0.0707 & 0.0198 & 3.57 & 0.0004 \\
\hline Trade Freedom & 0.1005 & 0.0300 & 3.35 & 0.0008 \\
\hline Business Regulation & 0.1833 & 0.0226 & 8.10 & $<0.0001$ \\
\hline Year 2002 & 0.1552 & 0.0224 & 6.94 & $<0.0001$ \\
\hline Year 2003 & 0.7043 & 0.0242 & 29.15 & $<0.0001$ \\
\hline Year 2004 & 0.6837 & 0.0282 & 24.26 & $<0.0001$ \\
\hline Year 2005 & 0.8725 & 0.0321 & 27.17 & $<0.0001$ \\
\hline Year 2006 & 0.7217 & 0.0337 & 21.39 & $<0.0001$ \\
\hline
\end{tabular}


Table 2.11: IEF Direct Effects Model

\begin{tabular}{|l|c|c|c|c|}
\hline Model 3 & Coefficient & SE & $\boldsymbol{t}$-value & $\boldsymbol{p}$-value \\
\hline Variable & -0.1194 & 0.0863 & -1.38 & 0.1664 \\
\hline Intercept & 0.4155 & 0.0095 & 43.52 & $<0.0001$ \\
\hline Gender & 1.7228 & 0.0114 & 150.73 & $<0.0001$ \\
\hline Skill & -0.3635 & 0.0474 & -7.67 & $<0.0001$ \\
\hline Prevention Focus & 0.1462 & 0.0021 & 70.78 & $<0.0001$ \\
\hline Age & -0.0015 & 0.000023 & -67.32 & $<0.0001$ \\
\hline Age Squared & 0.0167 & 0.0102 & 1.64 & 0.1006 \\
\hline College & -0.023 & 0.0068 & -3.29 & 0.0010 \\
\hline $\begin{array}{l}\text { GDP per Capita } \\
\text { (thousands) }\end{array}$ & -0.0121 & 0.0063 & -1.94 & 0.0525 \\
\hline Unemployment Rate & 0.0021 & 0.0019 & 1.07 & 0.2841 \\
\hline $\begin{array}{l}\text { Taxation/Government } \\
\text { Size }\end{array}$ & 0.0041 & 0.0029 & 1.42 & 0.1568 \\
\hline Property Rights & 0.0104 & 0.0022 & 4.82 & $<0.0001$ \\
\hline Sound Money & -0.0030 & 0.0016 & -1.89 & 0.0594 \\
\hline Trade Freedom & 0.0052 & 0.0017 & 3.11 & 0.0019 \\
\hline Business Regulation & 0.1691 & 0.0230 & 7.35 & $<0.0001$ \\
\hline Year 2002 & 0.6836 & 0.0250 & 27.34 & $<0.0001$ \\
\hline Year 2003 & 0.5604 & 0.0255 & 21.96 & $<0.0001$ \\
\hline Year 2004 & 0.7171 & 0.0270 & 26.52 & $<0.0001$ \\
\hline Year 2005 & 0.5405 & 0.0293 & 18.43 & $<0.0001$ \\
\hline Year 2006 & & & & \\
\hline
\end{tabular}

Results from the full model, which includes the hypothesized cross-level interaction effects, can be seen in Table 2.12 and Table 2.13. Italicized variables are the variables that were added to these models (not in previous models). In Model 4, I use the EFW institution measures, for Model 5, I use the measures from the IEF. Adding the interaction terms not only adds additional significance tests, but this also slightly changes the parameter estimates for the direct effects. However, the results for the full models are very similar to the direct effects models. Thus, my discussion of the hypotheses tests will be based upon the results from both of the full models. When I ran the full model, the software would not converge on a solution when the college slope was allowed to vary by 
country. Hence, this random slope was removed, and hypotheses 8 and 9 were not tested. Because that the model would not converge with a random college slope, it is likely that there is very little variation in this relationship by country and thus unlikely that any sort of significance would have been found for hypotheses 8 and 9 .

Table 2.12: EFW Full Model

\begin{tabular}{|c|c|c|c|c|}
\hline \multicolumn{5}{|l|}{ Model 4} \\
\hline Variable & Coefficient & SE & $t$-value & $p$-value \\
\hline Intercept & -0.2238 & 0.1021 & -2.19 & 0.0283 \\
\hline Gender & 0.4158 & 0.0096 & 43.51 & $<0.0001$ \\
\hline Skill & 1.7230 & 0.0114 & 150.63 & $<0.0001$ \\
\hline Prevention Focus & -0.4158 & 0.0448 & -9.21 & $<0.0001$ \\
\hline Age & 0.1469 & 0.0021 & 71.03 & $<0.0001$ \\
\hline Age Squared & -0.0016 & 0.000023 & -67.58 & $<0.0001$ \\
\hline College & 0.0152 & 0.0102 & 1.49 & 0.1350 \\
\hline $\begin{array}{l}\text { GDP per Capita } \\
\text { (thousands) }\end{array}$ & -0.0297 & 0.0064 & -4.65 & $<0.0001$ \\
\hline Unemployment Rate & 0.0070 & 0.0060 & 1.17 & 0.2431 \\
\hline $\begin{array}{l}\text { Taxation/Government } \\
\text { Size }\end{array}$ & 0.1111 & 0.0185 & 6.01 & $<0.0001$ \\
\hline Property Rights & 0.0819 & 0.0203 & 4.03 & $<0.0001$ \\
\hline Sound Money & 0.0527 & 0.0209 & 2.51 & 0.0119 \\
\hline Trade Freedom & 0.0943 & 0.0299 & 3.15 & 0.0016 \\
\hline Business Regulation & 0.1852 & 0.0226 & 8.20 & $<0.0001$ \\
\hline $\begin{array}{l}\text { Pre Focus* Property } \\
\text { Rights }\end{array}$ & -0.0982 & 0.0208 & -4.72 & $<0.0001$ \\
\hline $\begin{array}{l}\text { Pre Focus *Sound } \\
\text { Money }\end{array}$ & 0.0516 & 0.0270 & 1.91 & 0.0564 \\
\hline Year 2002 & 0.1545 & 0.0224 & 6.91 & $<0.0001$ \\
\hline Year 2003 & 0.7061 & 0.0242 & 29.23 & $<0.0001$ \\
\hline Year 2004 & 0.6860 & 0.0281 & 24.38 & $<0.0001$ \\
\hline Year 2005 & 0.8801 & 0.0321 & 27.40 & $<0.0001$ \\
\hline Year 2006 & 0.7304 & 0.0337 & 21.64 & $<0.0001$ \\
\hline
\end{tabular}

In the EFW (using Economic Freedom of the World) full model, taxation/government size is a statistically significant predictor of entrepreneurship 
$(0.1111 ; p<.0001)$ although in a different direction than hypothesized in hypothesis 1. Likewise, the business regulation coefficient is statistically significant $(0.1852 ; p<$ .0001 ), but in a different direction than hypothesized in hypothesis 2 . The coefficient for trade freedom is positive and statistically significant $(0.0943 ; p=.0016)$, which is consistent with hypothesis 3 . Property rights is positively related to self-employment $(0.0819 ; p<.0001)$ which supports hypothesis 4 . Finally, sound money is positively related to self-employment $(0.0527 ; p=: 0119)$, which is consistent with hypothesis 5 . The interaction between prevention focus and sound money is statistically non-significant $(0.0516 ; p=.0564)$. No support is found for hypothesis 6 . The interaction between prevention focus and property rights is statistically significant, but in the direction opposite of what is hypothesized $(-0.0982 ; p<.0001)$. Thus, there is no support for hypothesis 7 . 
Table 2.13: IEF Full Model

\begin{tabular}{|l|c|c|c|c|}
\hline Model 5 & Coefficient & SE & $\boldsymbol{t}$-value & $\boldsymbol{p}$-value \\
\hline Variable & -0.1739 & 0.0882 & -1.97 & 0.0486 \\
\hline Intercept & 0.4156 & 0.0095 & 45.52 & $<0.0001$ \\
\hline Gender & 1.7225 & 0.0114 & 150.69 & $<0.0001$ \\
\hline Skill & -0.4471 & 0.0473 & -9.45 & $<0.0001$ \\
\hline Prevention Focus & 0.1462 & 0.0021 & 70.78 & $<0.0001$ \\
\hline Age & -0.0015 & 0.000023 & -67.33 & $<0.0001$ \\
\hline Age Squared & 0.0164 & 0.0102 & 1.61 & 0.1082 \\
\hline College & -0.029 & 0.007 & -4.09 & $<0.0001$ \\
\hline $\begin{array}{l}\text { GDP per Capita } \\
\text { (thousands) }\end{array}$ & & & & \\
\hline Unemployment Rate & -0.0100 & 0.0063 & -1.60 & 0.1104 \\
\hline $\begin{array}{l}\text { Taxation/Government } \\
\text { Size }\end{array}$ & 0.0019 & 0.0019 & 0.97 & 0.3297 \\
\hline Property Rights & 0.0029 & 0.0029 & 1.01 & 0.3145 \\
\hline Sound Money & 0.0108 & 0.0023 & 4.65 & $<0.0001$ \\
\hline Trade Freedom & -0.0027 & 0.0016 & -1.68 & 0.0938 \\
\hline Business Regulation & 0.0053 & 0.0017 & 3.16 & 0.0016 \\
\hline Pre Focus *Property & -0.0077 & 0.0019 & -4.11 & $<0.0001$ \\
Rights & & & & \\
\hline Pre Focus ${ }^{*}$ Sound Money & 0.00036 & 0.00365 & 0.10 & 0.9225 \\
\hline Year 2002 & 0.1680 & 0.0230 & 7.30 & $<0.0001$ \\
\hline Year 2003 & 0.6811 & 0.0250 & 27.25 & $<0.0001$ \\
\hline Year 2004 & 0.5642 & 0.0255 & 22.09 & $<0.0001$ \\
\hline Year 2005 & 0.7240 & 0.0271 & 26.73 & $<0.0001$ \\
\hline Year 2006 & 0.5519 & 0.0294 & 18.74 & $<0.0001$ \\
\hline
\end{tabular}

In the full model using the Index of Economic Freedom (IEF) institution measures, the coefficient for taxation/government size is not statistically significant $(0.0019 ; p=.3297)$. Thus, there is no support for hypothesis 1 . The level of business regulation has a statistically significant effect of the likelihood of being self-employed $(0.0053 ; p=.0016)$; however, the relationship is positive, and the opposite of what was hypothesized in hypothesis 2 . Trade freedom is not statistically significantly related to 
self-employment $(-0.0027 ; p=.0938)$, which is not consistent with hypothesis 3 .

Property rights are not statistically significantly related to self-employment $(0.0029 ; p$

$=.3145$ ), thus this is not consistent with hypothesis 4 . Sound money is positive and

statistically significant $(0.0108 ; p<.0001)$, supporting hypothesis 5 . The interaction

between prevention focus and sound money was statistically nonsignificant $(0.0004 ; p=$

.9225). Thus, no support is found for hypothesis 6 . The interaction between prevention

focus and property rights was statistically significant but in the direction opposite of what was hypothesized $(-0.0077 ; p<.0001)$. Hypothesis 7 is therefore not supported. A summary of the hypothesized variables and their significance in models 4 and 5 can be seen in Table 2.14.

Table 2.14: Results Summary

\begin{tabular}{|l|l|l|l|}
\hline & \multicolumn{1}{|c|}{$\begin{array}{c}\text { Hypothesized Relationship } \\
\text { With Self-Employment }\end{array}$} & $\begin{array}{c}\text { Results- EFW } \\
\text { Measures }\end{array}$ & Results- IEF Measures \\
\hline H1 & Taxation/Government Size & Not supported & Not supported \\
\hline H2 & Business Regulation & Not supported & Not supported \\
\hline H3 & Trade Freedom & Supported & Not supported \\
\hline H4 & Property Rights & Supported & Not supported \\
\hline H5 & Sound Money & Supported & Supported \\
\hline H6 & $\begin{array}{l}\text { Prevention Focus* Sound } \\
\text { Money }\end{array}$ & Not supported & Not supported \\
\hline H7 & $\begin{array}{l}\text { Prevention Focus *Property } \\
\text { Rights }\end{array}$ & Not supported & Not supported \\
\hline H8 & $\begin{array}{l}\text { College*Taxation/Government } \\
\text { Size }\end{array}$ & Not supported & Not supported \\
\hline H9 & $\begin{array}{l}\text { College*Business Regulation } \\
\text { a }\end{array}$ & Not supported & Not supported \\
\hline
\end{tabular}


${ }^{a}$ These effects were not tested in the full model because the model would not converge with both a random college and prevention focus slopes. However, the college variable itself was not statistically significant, and a separate analysis (without a random prevention focus slope) failed to find statistically significant moderation effects.

\section{Post Hoc Analysis}

In some of the analyses, both taxation/government size as well as business regulation were positively related to self-employment, even though a negative relationship was predicted. For taxation/government size, there is good theoretical rational for why this relationship might be positive. As discussed earlier, there are tax benefits to self-employment, which will tend to increase as tax rates go up (Bruce \& Schuetze, 2004). Also, large governments can provide certain services (education, police protection) infrastructure (roads and bridges) and basic research that may be beneficial to entrepreneurs (Audretsch et al., 2005; Kirchhoff et al., 2007; Kreft \& Sobel, 2005). However, the positive relationship found between the level of business regulation is more difficult to explain. Why would individuals in countries with more business regulation be more likely to be self-employed? Business regulations would seem to impede small entrepreneurs while being less of an impediment to large and established firms. The measure of business regulation used in both the EFW and IEF included not only direct regulations to businesses regarding startup and price controls, but also regulations of labor and credit markets. In order to examine this in a little more detail, I break down the business regulation measure into the three sub-components: business startup and operating regulations, labor regulations, and credit/bank regulations. I use only the EFW index, since the IEF does not have labor regulations for all years. I then run an analysis 
using these three subcomponents in place of the aggregated business regulations measure. The results can be seen in Table 2.15 .

Not surprisingly, business and operating regulations is now a non-significant predictor of self-employment $(-0.0087 ; p=.6464)$. However, labor regulations $(0.0881$; $p<.0001)$ and credit regulations $(0.1115 ; p<.0001)$ are positively related to selfemployment. In countries with greater labor regulations, firms may be reluctant to hire workers since the labor costs are high. Since workers cannot be hired, they may be more likely to become self-employed as they are pushed into this type of work because of the regulations. It may be the case that credit regulations have a larger impact on bigger businesses and thus make small business more the norm. As a consequence, these countries may have more self-employment. It makes sense that business and operating regulations would not be positively related to self-employment. This helps explain the counterintuitive findings found in the main analysis. 
Table 2.15: Post Hoc Test- Multiple Regulation Measures

\begin{tabular}{|l|c|c|c|c|}
\hline Model 6 & & & & \\
\hline Variable & Coefficient & SE & t-value & p-value \\
\hline Intercept & -0.2350 & 0.1016 & -2.31 & 0.0207 \\
\hline Gender & 0.4171 & 0.0096 & 43.58 & $<0.0001$ \\
\hline Skill & 1.7227 & 0.0114 & 150.48 & $<0.0001$ \\
\hline Prevention Focus & -0.4145 & 0.0445 & -9.30 & $<0.0001$ \\
\hline Age & 0.1468 & 0.0021 & 70.84 & $<0.0001$ \\
\hline Age Squared & -0.0016 & 0.000023 & -67.40 & $<0.0001$ \\
\hline College & 0.0140 & 0.0102 & 1.37 & 0.1710 \\
\hline $\begin{array}{l}\text { GDP per Capita } \\
\text { (thousands) }\end{array}$ & -0.0279 & 0.0065 & -4.30 & $<0.0001$ \\
\hline Unemployment Rate & 0.00211 & 0.00614 & 0.34 & 0.7314 \\
\hline $\begin{array}{l}\text { Taxation/Government } \\
\text { Size }\end{array}$ & 0.1068 & 0.0186 & 5.75 & $<0.0001$ \\
\hline $\begin{array}{l}\text { Startup and Operating } \\
\text { Regulations }\end{array}$ & -0.0087 & 0.0190 & -0.46 & 0.6464 \\
\hline Labor Regulations & 0.0881 & 0.0124 & 7.11 & $<0.0001$ \\
\hline Credit Regulations & 0.1115 & 0.0179 & 6.21 & $<0.0001$ \\
\hline Property Rights & 0.0356 & 0.0219 & 1.62 & 0.1048 \\
\hline Sound Money & 0.0856 & 0.0222 & 3.86 & $<0.0001$ \\
\hline Trade Freedom & 0.0642 & 0.0293 & 2.19 & 0.0284 \\
\hline $\begin{array}{l}\text { Prevention } \\
\text { Focus*Property } \\
\text { Rights }\end{array}$ & -0.1071 & 0.0213 & -5.02 & $<0.0001$ \\
\hline $\begin{array}{l}\text { Prevention } \\
\text { Focus*Sound Money }\end{array}$ & & & & \\
\hline Year 2002 & 0.0505 & 0.0277 & 1.82 & 0.0682 \\
\hline Year 2003 & 0.6893 & 0.0247 & 27.85 & $<0.0001$ \\
\hline Year 2004 & 0.6549 & 0.0277 & 23.57 & $<0.0001$ \\
\hline Year 2005 & 0.8952 & 0.0353 & 25.33 & $<0.0001$ \\
\hline Year 2006 & 0.7315 & 0.0381 & 19.22 & $<0.0001$ \\
\hline & & & & \\
\hline
\end{tabular}

\subsection{DISCUSSION}

The results are informative in how formal institutions predict the likelihood that an individual is self-employed. Several previous studies have examined how institutions influence entrepreneurship, with many of them using economic freedom indices to 
measure institutions (Bjornskov \& Foss, 2008; McMullen et al., 2008; Sobel, 2008;). One large difference in this essay is that I do not try to predict country-level entrepreneurship rates, but instead examine individual decisions to engage in entrepreneurship (measured by whether they are self-employed). Although results similar to previous research would not be surprising, such agreement is not necessarily expected either. There does appear to be some similarities in results I found and previous analyses performed solely at the country-level.

I found a positive relationship between government size/taxation levels and the likelihood of self-employment with the EFW measure, and a non-significant relationship with the IEF measure. Past empirical research on the relationship between government size/taxation levels and levels of entrepreneurship has found mixed results, with some finding negative (Nystrom, 2008) and other studies finding positive relationships (Aidis, Estrin, and Mickiewicz, 2009; Bjornskow \& Foss, 2008; Wennekers, van Stel, Thurik, and Reynolds, 2005). This may explained to different measures of entrepreneurship, for example, Aidis, Estrin and Mickiewicz predict entrepreneurial entry instead of selfemployment. Also, many of the studies do not predict the likelihood that an individual will be an entrepreneur through the use of multi-level modeling, but instead look at aggregate self-employment rates at the country or state level.

While some studies have found a non-significant relationship between measures of business regulation and measures of entrepreneurship (Bjornskow and Foss 2008; McMullen, Bagby, and Palich 2008) others have found a negative relationship (Klapper, Laeven and Rajan, 2006; Sobel, Clark, and Lee, 2007; Nystrom, 2008, Van Stel, Storey, 
and Thurik, 2007). However, I found a positive relationship between the level of business regulations and the likelihood of self-employment. This is somewhat explained by the post hoc analysis which reveals that it is labor and credit regualtions that tend to be driving this relationship, while startup and operating regullations are not significantly related. Again, these differences may be due to the use of different methodoligies and measures.

Trade freedom is positively and significantly related to the likelihood of selfemployment with the EFW measure, while non-significant for the IEF measure. Past research has been mixed as well. Sobel, Clark, and Lee (2007) found that the average tariff rate is negatively related to total entrepreneurial activity, however, other research has shown a non-significant relationship between trade freedom and measures of entrepreneurship (McMullen et al., 2008; Nyström, 2008).

I found a positive relationship between property rights and the likelihood of selfemployment with the EFW measure, but a non-significant relationship with the IEF measure of property rights. The positive relationship seems fairly consistent with the past literature, generally strong property rights have been found to encourage investment (Besley, 1995; Johnson, McMillian \& Woodruff, 2002) and certain types of entrepreneurship (McMullen, Bagby, and Palich, 2008; Nystrom 2008). The relationship between sound money and the likelihood of being self-employed was the most robust relationship of any of the hypothesized variables- it significantly predicted selfemployment in all model specifications in which it was included as a variable. This is 
consistent with findings of Bjornskov and Foss (2008) but not with the findings of Nystrom (2008)

Besides the ability to control for a number of individual level factors, another advantage to using a multi-level analysis is the ability to test cross-level interactions. There were four cross-level interactions hypothesized. However, the results from the interaction test did not generally support the hypothesized interactions.

\subsection{LIMITATIONS AND FUTURE RESEARCH}

There are several limitations to this research. Although the GEM survey allows access to a large number of cross-country respondents, this survey does not include many countries, and seems to contain a disproportionate number of European countries. Africa in particular is underrepresented, containing only observations from Uganda and South Africa. This is a problem because the determinants of entrepreneurship in Europe are likely to be much different than those in Africa. Thus, my results may have limited generalizability. Another limitation with the GEM survey is the crudeness of some of the measures. Entrepreneurial skills and prevention focus (fear of failure) are measured by dichotomous variables. These sorts of measures may make sense in a large cross-country survey such as this, since questions with responses on a Likert-type scale may be difficult to translate accurately for all of the countries in which individuals are surveyed.

Nevertheless, the crude nature of the measures means that they are subject to a substantial amount of measurement error. Measurement error lowers the bivariate correlation between two variables, weakening the bivariate relationship (Chen \& Popovich, 2002) and making it less likely that a significant relationship will be found. However, with a 
statistical analysis containing multiple independent variables, it is impossible to know how the measurement error will impact the relationship between two variables. Also, when examining how country-level differences influence entrepreneurship, there is always the possibility of omitted variable bias. Countries vary on an almost infinite number of variables, many of which are unobservable and immeasurable.

Examining measures of entrepreneurship- such of self-employment, new startups, etc. give us an idea about the prevalence and predictors of entrepreneurship. Allowing individuals the choice to become entrepreneurs is not only a basic liberty, but it is also important to economic outcomes like job creation and economic growth (Carree, van Stel, Thurik, \& Wennekers, 2002; Fölster, 2000). However, saying that all entrepreneurship is desirable, and that more entrepreneurship is always good, is simply wishful thinking. This study does not fully capture how institutions influence the type of entrepreneurship that people engage in. Baumol (1990) argues that even if institutional forces do not change the level of entrepreneurship in an economy, they certainly do change the type of entrepreneurship that occurs. Thus, institutions may influence the relative ratio of productive entrepreneurship to unproductive and destructive entrepreneurship. In the early middle ages, institutions encouraged "entrepreneurship" that involved developing innovative weapons to aid in making warfare - likely due at least partially to the economic gains that could be captured through warfare (and perhaps the lack of other ways to gain wealth). Thus, although entrepreneurship existed, it was not focused on developing new consumer products or efficient production systems. Likewise in modern society, high levels of taxation may in fact encourage people to 
become self-employed (Bruce \& Schuetze, 2004), so they can take advantage of certain tax benefits (both legal and illegal) that self-employed individuals can take advantage of. These individuals may not particularly desire to be self-employed, and they may be less productive as self-employed than if they were working for some other firm. Likewise, with larger governments, individuals may become self-employed to perform consulting work for government. They may have incentives to lobby for special rules or regulations that might increase the demand for their services. However, in this study, due to the nature of the data, I am not able to separate productive entrepreneurship from unproductive and destructive versions.

Attempting to measure productive entrepreneurship and using institutional variables to predict productive entrepreneurship may be the logical next step in this research stream. One notable paper already attempts to make a distinction between productive and unproductive entrepreneurship and examines what institutional factors predict each (Sobel, 2008). In this paper, the distinction is made by using firm births, patenting activity, etc. as measures of productive entrepreneurship, and using the number of lobbying firms and the quality of the state's liability system. However, some new firms that come about are unproductive if not downright destructive. Attempts should be made to examine new firms on a number of criteria to determine whether they are to be considered productive, unproductive, or destructive.

Another fruitful area of future research may be examining the interactions between country-level institution measure and individual-level characteristics. Many factors that commonly predict engagement in entrepreneurial activities, such as risk 
perception, risk tolerance, and overconfidence and may have their effects moderated by institutional factors. While none of the hypothesized moderators in this study were supported, that does not mean that other moderating relationships do not exist.

\subsection{CONCLUSION}

In this essay, I examined the relationship between the formal institutions of a country and the likelihood of individuals being self-employed. Two sets of institutional measures, the Economic Freedom of the World index and the Index of Economic Freedom are used in the analysis to measure government size, the level of business regulation, trade freedom, the strength of property rights, and soundness of money. Some support is found for a positive relationship between trade freedom, property rights, and sound money in the country in which an individual resides and the likelihood that they are engaged in self-employment. Government size/taxation levels and the level of business regulations do not predict engagement in self-employment in the hypothesized manner. 


\section{CHAPTER 3: LABOR MARKET INSTITUTIONS AND NEW FIRM EMPLOYMENT GROWTH}

\subsection{INTRODUCTION}

Labor market institutions include the taxes on labor, minimum wages, employment regulations, social security taxes and benefits, and laws governing unionization in an economy (Nickell 1998). Labor market institutions develop over time, often as a result of various social movements and economic shocks (Thelen, 2004) and vary widely across countries and sometimes even among regions or states within a country. Because these institutions set the rules for both employees and employers, they ultimately influence the cost of labor and affect hiring, firing, and other employment decisions within the firm. For example, labor market institutions have been shown to influence a number of economic outcomes, such as the variance in pay levels (Freeman, 1998), unemployment rates (Ljungqvist \& Sargent, 1998; Nickell, 1997) and job creation (Cahuc \& Postel-Vinay, 2002).

Existing research has focused on using labor market institutions to predict economy-level outcomes, such as the level of unemployment (Belot \& Van Ours, 2001) and variation in wages (Siebert, 1997). For these economy-level outcomes to arise, institutions need to change the behavior of firms and individuals. However, how labor 
market institutions specifically influence the behavior of new firms is not well understood. New firms often are resource-constrained and have less access to capital than more established firms (Carpenter \& Petersen, 2002; Holtz-Eakin, Joulfaian, \& Rosen, 1994), yet they require substantial increases in employment in order to grow. Often they operate in "hypercompetitive" industries with small profit margins (Jones, Ram, \& Edwards, 2004; Ram, Edwards, \& Jones, 2007). New firms may be more sensitive to labor market institutions that increase the cost of labor, since they may lack access to capital and compete in very competitive industries. Alternatively, new firms may be less sensitive to some labor market institutions such as those that encourage unionization because their initial small size may reduce their chances of being unionized. In addition, new firms may be able to effectively avoid the impact of high minimum wages by informally hiring people "off the books" or by renegotiating other details of the employment contract to compensate for having to pay high wages (Arrowsmith, Gilman, Edwards, \& Ram, 2003). However, current research has not rigorously examined how labor market institutions such as minimum wages, unionization protections, and labor taxes influences new firms.

In this essay, I examine the following research question: Do labor market institutions influence employment growth in new firms? New firms are often small, and small firms are said to suffer from the liability of smallness ${ }^{3}$ (Bruderl $\&$ Schussler, 1990) because they often lack the necessary resources needed to survive (Holtz-Eakin et al.,

\footnotetext{
${ }^{3}$ New firms are said to suffer from the liability of newness because they lack legitimacy and must learn new routines, which raises their mortality rate (Stinchcombe, 1965). However, new firms are most often small and, therefore, suffer from the resource constraints associated with the liability of smallness as well. Although conceptually different, many new firms arguably have both types of liabilities.
} 
1994). Labor market institutions may exacerbate this liability by increasing the labor cost of new firms. Thus, answering this question will build on previous findings suggesting that the institutional environment may have a profound impact on emerging firms (Campbell \& Rogers, 2007; Sobel et al., 2007). Furthermore, this paper examines how firm attributes, such as whether a firm has a competitive advantage, moderate the relationship between labor market institutions and firm employment. Because new firms are often considered significant creators of new jobs (Birch, 1987; Birley, 1986; Davidsson, Lindmark, \& Olofsson, 1998; Van Praag \& Versloot, 2007; Van Stel \& Suddle, 2008), an understanding of to what extent their labor market policies influence employment growth in these firms can aid decision making by policymakers.

This essay is organized as follows. First, I develop several hypotheses concerning the relationship between various labor market institutions and employment growth in new firms. I examine several aspects of labor market institutions: minimum wages, union densities, and the structure of unemployment insurance. I then test these relationships by combining state-level measures of labor market institutions with firm-level measures from the Kauffman Firm Survey.

\subsection{LABOR MARKET INSTITUTIONS}

Siebert (1997) notes, "any labor market is surrounded by an array of institutional arrangements that form a complex web of incentives and disincentives on both sides of the market" (p. 39). Labor market institutions include the taxes on labor, minimum wages, employment regulations, social security taxes and benefits, and laws governing unionization in an economy (Nickell 1998). The rules that regulate the labor market 
influence the supply and demand for labor (Freeman, 1998; Siebert, 1997). These rules and regulations differ greatly among countries, with different countries developing several distinct models with varying results. As noted by Freeman (1998), the U.S. model entails relatively low union protection, low minimum wages compared to the average wage, and a weak social safety net. The U.S. has experienced rather low unemployment and high growth but has experienced low inflation-adjusted wage increases relative to many European countries. Conversely, many European countries are characterized by relatively high levels of unionization, high minimum wages, and extensive social safety nets, although differences do manifest themselves among European countries. During the 1980s and 1990s, many European countries had substantially higher unemployment rates than the U.S., although there was generally less variance in pay levels (Blanchard \& Summers, 1986; Freeman, 1998; Ljungqvist \& Sargent, 1998). The differences between European countries and the U.S. in unemployment rates persisted into the 2000s, until the financial crisis in 2008 and 2009 when the rates converged (Schmitt, Rho, \& Fremstad, 2009). The differences in economic outcomes among these countries are to some degree a result of differences in labor market institutions (Belot \& Van Ours, 2001; Freeman \& Nickell, 1988; Siebert, 1997).

In addition to labor market institutions varying widely by country, substantial variation in these institutions also occurs between the various states or provinces inside some countries. This can clearly be seen in countries with a federalist system, which grants substantial governing power to individual states or provinces, such as in the U.S. 
and Canada (Karabegovic et al., 2005). For example, in the U.S., states can enact their own minimum wage laws ${ }^{4}$, set right-to-work laws, determine acceptable firing practices, and determine on what basis firms may discriminate in employment (Colvin, 2000; Karabegovic et al., 2005).

\subsection{LABOR MARKET INSTITUTIONS AND NEW FIRMS}

As discussed, labor market institutions have a broad impact on labor market outcomes, affecting working conditions, employee wages (Freeman, 1998), firm profitability (Voos \& Mishel, 1986), unemployment levels (Siebert, 1997), and worker productivity (Addison \& Barnett, 1982). Labor market institutions have a substantial impact on firms, and new firms are no exception. However, labor market institutions may play a greater role in influencing hiring and firing in new firms for several reasons. New firms also are generally small, lack resources, and do not have as easy access to capital as more established firms (Carpenter \& Petersen, 2002; Holtz-Eakin et al., 1994). Furthermore, new firms have a substantial need for additional resources in order to grow. New firms are often not yet profitable and cannot use their profits to fund expansion; therefore, they often must rely on external resources to operate and grow. Due to these resource constraints, increased labor cost of any sort may lead to new firms be less willing to hire workers and more willing to lay off workers than older firms.

\footnotetext{
${ }^{4}$ Although states do enact minimum wage laws, they are not able to enact a minimum wage lower than the federal minimum wage in the United States. Thus, firms in states that have no minimum wage laws or minimum wages below the federal minimum wage must pay the federal minimum wage.
} 
To examine how labor market institutions impact new firms, I examine how minimum wages, as well as unionization levels and unemployment tax policies, influence the employment levels of new firms.

\section{Minimum Wages}

The first national minimum wage in the U.S. of 25 cents per hour was enacted by the Fair Labor Standard Act of 1938 (Grossman, 1978). Some individual states adopted a minimum wage prior to the Fair Labor Standard Act, but often these rules only applied to children and/or female workers (Leonard, 2000). Even though a national minimum wage is in effect in the U.S. today, many states have their own minimum wage rates as well (Karabegovic et al., 2005). In 2009, all but five states had their own minimum wages, although some had rates below the federal minimum wage. Washington state had the highest minimum wage at $\$ 8.55$ per hour, while the federal minimum wage was increased to $\$ 7.25$ that year (United States Departrnent of Labor, 2009).

Neoclassical economic theory suggests that all else being equal, a higher minimum wage will lead to lower levels of employment and higher levels of unemployment (Stigler, 1946). Increases in the minimum wage raise the marginal cost of each additional employee; as a result, firms reduce the number of employees. Most empirical studies have found a negative relationship between increases in the minimum wage and employment (Baker, Benjamin, \& Stanger, 1999; Neumark \& Wascher, 2000). Generally, a 10 percent increase in the minimum wage reduces teenage employment between zero to three percent (Brown, Gilroy, \& Kohen, 1982). 
A few studies have found insignificant or positive relationships between minimum wages and employment levels (Card \& Krueger, 1994; Card \& Krueger, 1995; Dickens, Machin, \& Manning, 1999). Explanations include monopsony labor markets, or countervailing forces that could minimize or eliminate a negative relationship between minimum wages and employment. These include possible "shock effects" in which employers react to increases in the minimum wage by raising their workers' productivity to compensate for the increased minimum wage (Brown et al., 1982) as well as the possibility that firms reduce employee compensation in other ways (Brown \& Crossman, 2000). Finally, the "hungry teenager" hypothesis notes that increases in the minimum wage will lead to increased earnings among teenagers (Kennan, 1995; Zavodny, 1998). Because teenagers often spend their money at places such as fast food restaurants that employ workers at the minimum wage, the demand curve for low skilled labor is shifted right (Antonova \& Tudoreanu, 2009). Thus, employment levels do not change or change very little because of minimum wage increases.

Several researchers have questioned the findings of the studies by Card and Krueger $(1994,1995)$ and have reexamined these studies empirically. Card and Krueger's (1995) study of the 1990-1991 minimum wage increase found no relationship between minimum wages and teenage employment. However, Wessels' (2007) replication of the analysis applying the Card and Krueger (1995) model to the 1996-1997 federal minimum wage increase found that the higher minimum wage is associated with lower teenage employment in states that were more affected by the minimum wage increase. Neumark and Wascher (2000) suggest that econometric and measurement issues may have led to 
an incorrect conclusion in the analysis by Card and Krueger (1994) on the impact of the New Jersey minimum wage increase on employment levels in the fast food industry. They replicated the analysis using payroll data instead of telephone surveys and generally concluded that the minimum wage increase did reduce employment.

In addition to econometric and measurement issues, one possibility for the differing findings in some of the minimum wage research is that increases in the minimum wage may not affect all firms the same way regarding their hiring and firing activities. Rama (2001) examined the case of the minimum wage doubling in Indonesia and found that while small firms decreased their employment substantially, large firms actually increased employment. Therefore, if minimum wages affect firms with varying attributes in different ways, then perhaps the differing results that have been found regarding the relationship between minimum wages and employment may be due to heterogeneous samples.

\section{Minimum Wages and New Firms}

Minimum wages are likely to increase a firm's labor cost for unskilled employees (Gregg, 2000). If the minimum wage rate rises above the marginal revenue generated by workers, then they are likely to be laid off (if working for a firm) or not hired (if not working for a firm) (Leonard, 2000). Thus, high minimum wages in a state are likely to lead to lower levels of employment relative to firms in low minimum wage states.

Newer firms are likely to behave differently in response to high minimum wages than older firms. New firms differ from established firms in that they may not currently 
be generating much revenue from their employees and thus may not have access to needed capital, even if it can be invested productively. When firms are new, employees may be working on activities that may not necessarily be profitable for the firm in the short-term, but may be in the long-term. For example, a new restaurant may be paying employees a wage (marginal cost) that exceeds the additional revenue that employee actually generates for the firm (marginal revenue). That is because firm may have few initial customers, but wants to keep a sufficient number of employees on the payroll to ensure that customers receive prompt service. Doing so may allow the firm to be successful in the future, as satisfied customers become repeat customers of the business and tell their acquaintances about the positive experience they had.

Although the marginal revenue generated by an employee may exceed their marginal cost, the cost is realized immediately while the revenue may not be realized until far into the future. This would not be particularly problematic if capital markets worked efficiently; the new firm would simply borrow the money they needed to hire such workers and pay it back later. However, given evidence that small and new firms face liquidity constraints (Holtz-Eakin et al., 1994; Johansson, 2000), increased labor cost may lead to new firms limiting the number of people that they employ, even when employing a greater number of people would be profitable in the end.

Several other factors may make high minimum wages particularly problematic for new firms as well. New firms are typically small, and small firms typically pay lower wages than large firms (Brown \& Medoff, 1989; Idson \& Feaster, 1990; Morissette, 1993; Winter-Ebmer, 2001). Therefore, these firms are likely to have a larger percentage 
of their workers earning the minimum wage, making high minimum wages more costly to these firms. Small, new firms often operate in markets that are known as "hypercompetitive," and firms in these types of markets have low profit margins, making their ability to deal with high labor cost difficult (Jones et al., 2004; Ram et al., 2007).

Although traditional economic theory predicts that a number of negative consequences may result from high minimum wages, others argue that the actions that firms take in responding to increased minimum wages may be hard to predict (Arrowsmith et al., 2003). Despite the fact that high minimum wages may be a major burden for new firms, sometimes they may be able to respond to high minimum wages in creative ways and avoid having to reduce the number of workers that they employ. Contracts between employers and employees can be renegotiated to avoid or minimize the impact of the minimum wage on the firm (Arrowsmith et al., 2003). One way this is done is through circumventing the law. For example, informal arrangements may be made in which employees work "off the books," that is, are not registered as employees, and receive wages paid in cash. Employers could pay these workers' wages below the minimum wage. Employees may agree to such arrangements when they are threatened with termination, if they receive other benefits (such as tax benefits) from the arrangement, or have few alternatives for employment (such as in the case of illegal immigrants). Furthermore, ties between the employer and employees, especially in groups of ethnic minorities, may serve to enforce these sorts of arrangements (Jones et al., 2004; Ram et al., 2007). Because new firms are typically small and lack formal human resources practices (Cardon \& Stevens, 2004; Wager, 1998), informally 
renegotiating such contracts, even when technically illegal, is likely to be much easier than in more established firms that have formal human resource procedures. Even if employers agree to pay a high minimum wage, they may change other parts of the employment contract to compensate for the extra payment. For example, firms may require employees to work harder and be subject to more critical employee reviews (Arrowsmith et al., 2003). Firms can cut employee pay in other ways, such as offering fewer vacation days, less paid overtime, and fewer employee discounts and making breaks unpaid (Brown \& Crossman, 2000).

Although new firms certainly may adapt substantially to high minimum wages using a number of techniques, it seems unlikely that new firms will be able to adapt to minimum wages so well that their employment levels will not be affected. Thus, high minimum wages are likely to exert a negative impact on employment levels in new firms.

\section{H1: New firms operating in states with higher minimum wages will have lower employment growth than new firms operating in states with lower minimum wages.}

\section{Union Protections and Union Density}

Union density, the percentage of workers that are represented by unions, varies dramatically among U.S. states. In 2008, the percentage of employees represented by unions in the U.S. ranged from a low of $4.6 \%$ of workers in Georgia to $26.6 \%$ of workers in New York, with an average of 12.9\% (Bureau of Labor Statistics, 2010). 
The level of unionization in a region is likely influenced by statutory laws, such as legal protections, cultural acceptance of unions, as well as the type of industries in the region. One way it is thought that state governments can influence the prevalence of unionization in their states is through enacting (or failing to enact) right-to-work laws. Right-to-work laws remove the requirement to join a union to get or maintain a job (Lumsden \& Petersen, 1975). The Taft-Hartley act passed in 1947 allowed individual states in the U.S. to pass right-to-work laws if they chose. As of 200922 states had rightto-work laws (U.S. Department of Labor, 2010).

Some research has found little or no relationship between right-to-work laws and unionization levels (Wessels, 1981), while others have found a negative relationship (Ellwood \& Fine, 1987; Moore, 1998). Even when a relationship is observed between union density and the presence of right-to-work laws, it is difficult to say that the presence of right-to-work laws causes union density to decrease. The relationship may be endogenous because many of the states that have enacted right-to-work laws are states in which unions were not strong to begin with (Farber, 1984; Moore \& Newman, 1985) and therefore have less political power. Conversely, states with traditionally high levels of union membership and union power, such as Pennsylvania and Michigan, have not enacted right-to-work laws. Thus, a simultaneity bias problem ${ }^{5}$ seems to exist in which it is not clear whether right-to-work laws lead to lower levels of unionization or whether low levels of unionization leads to less opposition to right-to-work laws, making their

\footnotetext{
${ }^{5}$ A simultaneity bias (or reverse causality) is a form of endogeneity in which the dependent variable may also influence the independent variable. Endogeneity may also occur due to an omitted variable that influences the dependent variable and also is correlated with one or more of the independent variables (Verbeek, 2008).
} 
enactment more likely. However, Davis and Huston (1995) and Moore (1998) both found that right-to-work laws are associated with lower union densities even when accounting for the simultaneity bias problem.

Another factor likely to influence the level of unionization is a region's culture. Culture not only influences how favorably a society views unions but also affects the enactment of laws that may be beneficial (or not) to unions. Cultural measures of uncertainty avoidance, individualism, masculinity, and power distance are significant predictors of union density, with cultures that value masculinity and accept inequity displaying low union densities (Singh, 2001). Public support for unionization may relate to union density as well. Lower public support for unions during the 1980 s occurred during a period of substantial decline in private sector union density (Palley \& LaJeunesse, 2007). In addition to formal institutions and culture, the level of unionization in a region is influenced by the types of industries and industry structure that are prevalent in the region. Unionization has generally been higher in areas associated with manufacturing, such as the Northeast and Midwest regions of the U.S. (Kokkelenberg \& Sockell, 1985). Conversely, areas with traditionally low levels of manufacturing, such as the Southeast and Great Plains regions, have had lower union densities.

Researchers have examined the effects of unionization on firms as well. Unionization tends to lead to higher wages (Duncan \& Stafford, 1980; Kwoka Jr, 1983; Stewart, 1990), and higher wages provide incentives for firms to substitute capital in place of labor, raising productivity (Addison \& Barnett, 1982). However, any 
relationship between unionization and worker productivity is likely confounded by a selection effect. Because firms that are unionized pay more for workers, they likely will only select the highest quality workers to hire (Addison \& Barnett, 1982).

It is often argued that unionization of a firm's workforce will have a negative impact on firm profitability. Unionized workers tend to get paid more than nonunionized workers (Duncan \& Stafford, 1980; Kwoka Jr, 1983; Stewart, 1990), which could lead to firms either raising prices or having lower profits. Voos and Mishel (1986) find that unions in the supermarket industry substantially reduce profits of supermarkets and this effect is more pronounced when there is a high level of concentration in local markets. Likewise, evidence from Britain suggests that unions have a negative impact on firm profitability (Menezes-Filho, 1997). A study of U.S. firms found that unionized firms had profitability that was $10 \%-15 \%$ lower than firms that were not unionized (Hirsch, 1991). High levels of unionization also have a strong negative impact on the level of new business activity within states (Bartik, 1985).

\section{Union Density and New Firms}

Because unionized workers typically are paid more than non-unionized workers are, a firm's cost are likely to be higher if its workforce is unionized (Bratsberg \& Ragan Jr, 2002; Freeman \& Medoff, 1984). Thus, unionization leads to more expensive workers (Freeman \& Medoff, 1984; Kaufman \& Kaufman, 1987), and firms that hire unionized workers tend to hire fewer workers and to substitute capital for labor (Clark, 1984). This effect may be particularly pronounced in new firms that become unionized because these firms are often small and weak and yet may have to negotiate with an established labor 
union (Freeman \& Medoff, 1984). However, when firms start, typically their workforce is not unionized, even if the firm operates in an inclustry or geographical region that is heavily unionized. This is because it is difficult for workers to unionize in small, new firms (Acs \& Audretsch, 1989; Miller \& Mulvey, 1996), which typically have few employees, a large percentage which are part-time (Bélanger \& Murray, 1994; Galarneau, 1996). Even if the new firm is located in a state that has labor institutions favorable to union organizing, it is unlikely that the firm's employees will unionize until the firm has grown larger.

However, the presence of high union densities in the state in which a firm operates could affect a new firm in a couple of ways. As a firm grows, there may be more pressure for the employees to unionize. In comparison to non-unionized workers, unionized workers typically earn higher salaries for similar jobs (Christie, 2007; Freeman \& Medoff, 1984; Kaufman \& Kaufman, 1987; Kornfeld, 1993). Therefore, this pressure may cause the owner(s) to avoid growing too large, keeping the firm small to avoid unionization. A high level of unionization in the firm's region can hurt new firms in other ways even if the firm's employees are not unionized and cannot realistically threaten organizing. Because unionized firms must pay higher wages anyway, they are likely to hire the highest quality workers (Freeman \& Medoff, 1984; Mellow, 1981). Unionized firms are likely to pay these highly qualified workers well, thus new firms may have more difficulty obtaining high-quality workers at a reasonable cost in states that have high union densities. 
Alternatively, high union densities in a state could be favorable to new firms because they are unlikely to be unionized due to their size and youth; whereas, larger established firms in the state more likely will be (Acs \& Audretsch, 1989; Miller \& Mulvey, 1996). Thus, when union densities are high, many existing firms in the state may have labor costs that are relatively high in comparison to new firms operating in the state, which are likely not unionized. Also, if unions are successful in negotiating high wages for their employees, firms that are unionized will tend to hire fewer employees than they otherwise would (Freeman and Medoff, 1984). However, nonunionized firms will not have this disincentive to hire.

It has been observed that small firms typically pay lower wages than larger firms (Brown \& Medoff, 1989; Idson \& Feaster, 1990; Morissette, 1993; Winter-Ebmer, 2001). Although there are several reasons for this, the fact that small firms are often not unionized may contribute to this observed difference. The higher labor cost experienced by some incumbent firms that are unionized will likely lead to limited hiring of employees due to the high cost of hiring well-paid unionized workers, while new firms that are not unionized will not be forced to limit their hiring due to high union wages. Because new firms that are not unionized will not have to pay a high wage for labor, they will likely increase employment levels as they are able given their capital, revenue, and need for labor.

Compared to new firms in regions in which union densities are relatively low, new firms in areas of high union densities may tend to hire more employees. New firms will likely have an advantage in labor cost relative to existing firms that are likely to be 
unionized (Clark, 1984). Therefore, new firms will be able to grow and expand their employment at the cost of existing incumbent firms. New firms in states with low union densities will have no such advantage.

\section{H2: New firms operating in states with higher union densities will have higher employment growth than new firms operating in states with lower union densities.}

\section{Unemployment Insurance}

Unemployment insurance is insurance that pays workers a portion of their wages in the event that their job is involuntarily terminated". The "premium" for this insurance is paid for by the firm for which an individual works. Unemployment insurance programs are joint federal-state programs, and states set their own unemployment tax schedules that they collect from employers (Anderson \& Meyer, 1993). Unemployment insurance taxes are often levied on firms based upon the number of employees they have (Padgitt, 2009). This is essentially a tax on employment, which increases the cost of labor for firms. In addition to affecting incentives to seek employment, unemployment insurance is also likely to influence the hiring and firing behavior of firms, especially because they are forced to pay the insurance premiums. Therefore, high premiums may work as a disincentive for firms to hire workers because it makes each employee more expensive. However, the incidence of the tax may be borne by workers. Anderson and Meyer (1993) found that high unemployment insurance premiums are absorbed by workers in the form of lower wages, minimizing any negative impact on hiring.

\footnotetext{
${ }^{6}$ Generally, the termination cannot be due to a disciplinary action to receive unemployment insurance.
} 


\section{Unemployment Insurance and New Firms}

Because states' policies regarding unemployment insurance vary (Anderson \& Meyer, 1993), the level and structure of unemployment insurance taxes in a state may influence the employment levels of new firms. Typically, firms must pay unemployment insurance taxes for every worker that they employ. The structure of how these taxes are calculated tends to vary from state to state, and their determination can be complicated. The actual rates charged are a function of the statutory ranges that each state sets, the amount of money in the state unemployment fund, the industry in which the firm competes, and the firm's past experience with regards to worker layoffs (Padgitt, 2009).

States make several choices when determining unemployment tax rates and these rates may have a substantial financial impact on firms. First, policymakers decide the maximum and minimum rates that firms can be charged (Padgitt, 2009). States also determine the degree to which employee layoffs will affect the insurance premiums. When unemployment insurance benefits are successfully collected by a worker, the benefits that they receive are charged to the worker's former employer(s) using a formula determined by the state. Thus, the amount that a firm pays is somewhat dependent on the frequency in which its former employees have qualified for unemployment benefits. In some states, a firm that terminates an employee is charged for the benefits that worker receive, thus penalizing firms when they downsize their workforce. Other states charge all of the worker's former employers over some span of time (such as the past year) or charge all of the former employers of the worker over a span of time in proportion to the amount of wages that that the worker earned from each employer (Padgitt, 2009). 
Unemployment tax structures that heavily penalize downsizing firms make labor cost a quasi-fixed cost. Thus, when making employment decisions, firms will not only consider current marginal revenue and marginal cost but also will consider future production levels (Oi, 1962). An unemployment tax structure in which charges for all the unemployment benefits when layoffs occur will be particularly burdensome (Padgitt, 2009) and is likely to reduce the incentive of firms to hire employees if they think that they will have to lay off these workers in the future. Likewise, new firms will be discouraged from hiring workers when the unemployment tax rates are high, due to their lack of capital and the difficulty they have obtaining it (Blanchard \& Tirole, 2008).

\section{H3: New firms operating in states with unemployment taxes that are high and that penalize firms for worker layoffs will have lower employment growth than new firms operating in states with unemployment taxes that are low and that do not penalize firms for worker layoffs.}

\subsection{METHODS AND RESULTS}

\section{Sample}

Firm data are obtained from the Kauffman Firm Survey (KFS), which is a longitudinal survey of new firms. To find firms to participate in the KFS, firms are randomly selected from Dun and Bradstreet's database of new businesses started in 2004 (Fairlie \& Robb, 2009). To be eligible to participate in the KFS, firms had to perform at least one the following activities in 2004 and could not have performed any of these in the previous year (2003): 
- Payment of state unemployment taxes.

- Payment of FICA taxes.

- Presence of a legal status for the business.

- Use of an Employer Identification Number

- Use of Schedule $\mathrm{C}$ to report business income on a personal tax return.

These criteria were adopted to assure that firms selected to participate in the KFS were actually new firms that were beginning operations.

Data for the baseline survey were collected from July 2005 to July 2006 from principals representing 4,928 new firms that were started in 2004 (DesRoches et al., 2009). Respondents were paid $\$ 50$ to complete the survey to ensure a high response rate. Approximately $77 \%$ of respondents completed the survey using Computer Assisted Telephone Interviewing (CATI) while $23 \%$ completed the internet survey. Plans were made to collect multiple waves of data after the baseline survey, and to date, four subsequent waves have been collected and are used in the analysis. In subsequent waves, respondents also had a choice whether to use CATI or the internet to complete the survey and were paid an additional $\$ 50$ for each wave of data collection in which they participated. Thus, firm-level data for years 2004, 2005, 2006, 2007 and 2008. The numbers of surveys completed each year are as follows: $2004=4,928 ; 2005=3,998$; $2006=3,390 ; 2007=2,915$ and $2008=2,606$ (Kauffman Foundation, 2011). This totals to 17,837 observations. Thus, $18.9 \%$ of initial respondents were lost for wave $2,15.2 \%$ for wave $3,14.0 \%$ for wave 4 , and $10.6 \%$ for wave 5 . A cumulative loss of $47.12 \%$ of initial firms was experienced by wave 5 . 
One limitation to the Kauffman Firm Survey data for this research is that it contains an oversample of high-technology firms. High-technology firms are quite different from low-technology firms in that that they have a need for workers that have high levels of human capital and these firms spend significant resources further developing the human capital of their employees (Baldwin \& Gellatly, 1998; Darby, Liu, \& Zucker, 1999). Conversely, many low-technology firms, such as retailers and restaurants, tend to hire many workers with lower levels of human capital. For lowtechnology firms hiring lower-skilled workers, substantial minimum wages are likely to have a large impact on the cost of hiring additional employees (Partridge \& Partridge, 1999). Conversely, in high-technology firms, high minimum wages are not likely to substantially increase the cost of labor because the types of employees they typically hire are earning wages far in excess of the minimum wage. Growth in employees for hightechnology firms will likely be driven by firm needs, with minimum wages having little impact on decisions to hire additional employees. Thus, the high-technology firms are removed from the data. Additionally, firms in the medical, insurance and finance industries are removed as well. Specifically, all firms in industries starting with " 5 " in their NAICS codes are removed $(51=$ information; 52 = finance and insurance; $53=$ real estate and rental leasing; $54=$ professional, scientific, and technical services; $55=$ management of companies and enterprises; $56=$ administrative and support and waste management and remediation services. Industries starting with 61 (educational services), 62 (health care and social assistance), and 90 (public administration) were also removed. For a count of firms remaining in the sample by industry, see Table 3.1 . 
Table 3.1: Observations by Wave \& Industry

\begin{tabular}{|l|c|c|c|c|c|}
\hline $\begin{array}{l}\text { Industry } \\
\text { (NAICS) }\end{array}$ & Baseline & Follow Up 1 & Follow Up 2 & Follow Up 3 & $\begin{array}{c}\text { Follow Up } \\
\mathbf{4}\end{array}$ \\
\hline $\mathbf{1 1}$ & 40 & 34 & 31 & 28 & 28 \\
\hline $\mathbf{2 1 - 2 3}$ & 391 & 311 & 270 & 234 & 210 \\
\hline $\mathbf{3 1 - 3 3}$ & 703 & 590 & 510 & 453 & 394 \\
\hline $\mathbf{4 2 - 4 9}$ & 884 & 659 & 550 & 461 & 402 \\
\hline $\mathbf{7 1}$ & 200 & 153 & 125 & 110 & 106 \\
\hline $\mathbf{8 1}$ & 444 & 360 & 316 & 264 & 251 \\
\hline Total & 2,662 & 2,107 & 1,802 & 1,550 & 1,391 \\
\hline & & & & & \\
\hline
\end{tabular}

This leaves 2,662 observations in the baseline wave, 2,107 observations in the first follow up wave, 1,802 observations in the second follow up wave, 1,550 observations in the third follow up wave, and 1,391 in the fourth follow up wave.

\section{Measures}

\section{Dependent Variable}

The KFS dataset contains data on the number of employees the firm has in each of the waves in which data were collected. In the baseline wave, only about $40 \%$ of all firms had employees, although this increases in subsequent waves. In addition to the baseline wave, data on employment were collected on the four follow-up waves; therefore, employment data will be available for 2004, 2005, 2006, 2007 and 2008 (DesRoches et al., 2009). Because the number of employees is highly right skewed, a natural $\log$ transformation is used to make the distribution more normal. 


\section{Independent Variables}

The independent variables of interest are the labor market institutions of the state in which a firm resides. Three state-level labor market measures are used for each year: (1) the minimum wages, (2) union densities, and (3) and an index that reflects how burdensome the unemployment tax systems are for firms. I obtained minimum wage data for U.S. states from the U.S. Department of Labor (2010). I then calculated the difference between the state minimum wage and the federal minimum wage. I obtained union densities values from the Current Population Survey (CPS) conducted by the Bureau of Labor Statistics and Census Bureau (2010). Union densities are based on union coverage, not union membership. This provides a better measure of what percentages of workers receive the benefits of unionization, regardless of whether they are union members. I obtained unemployment tax data from the Tax Foundation, which provides an index that scores how costly the unemployment tax is on businesses for each state (Padgitt, 2009). The score takes into account the range of the possible tax rates as well as how the taxes are allocated to firms. High scores represent states with unemployment taxes that are low and that do not overly penalize employers for laying off workers. States with high values on this index have unemployment insurance "premiums" or taxes that are less costly to firms than states with low values.

\section{Control Variables}

The industry in which a firm competes will determine how fast a firm grows as well as its need for labor (Fariñas \& Moreno, 2000; Hall, 1987). Service firms, which include restaurants and retailers, rely on large amounts of cheap, unskilled labor more 
likely to be earning the minimum wage (Card, 1992; Kim \& Taylor, 1995). To control for the firm's industry, I created a series of dummy variables to represent the NAICS code for the firm's industry using the first digit of the NAICS code. The omitted NAICS code is industry 4 (retail trade, wholesale trade, and transportation and warehousing) I used a measure for competitive advantage taken from the following question in the KFS survey: "Businesses often have to compete with other businesses. A competitive advantage is something unique or distinctive a business provides that gives it an advantage compared to competitors. In calendar year , did name of business have a competitive advantage over its competitors?" The dummy variable representing competitive advantage is coded as follows: $1=$ competitive advantage; $0=$ no competitive advantage.

High state unemployment rates may also influence a firm's level of employment because high unemployment may signify poor economic conditions that may make it unprofitable to hire and maintain a high number of employees. Thus, I controlled for state-level unemployment rates using the state-level unemployment rate obtained from the U.S. Department of Labor for the years 2004-2008.

\section{Analysis}

I hypothesize that state-level labor market factors will influence the employment level in new firms located in those states. The firms in the sample are clustered in states; thus, state-level factors may influence how quickly firms grow. This creates a problem for regular OLS regression because the firm observations are not independent and errors are likely to be correlated among firms within the same state (Raudenbush \& Bryk, 
2002). Furthermore, these data are longitudinal; data collected over time from the same firms are likely to be correlated as well (Bliese, 2009). Thus, the repeated observations are nested within firms, and firms are nested within state. Thus, to perform these analyses, random coefficient multilevel (RCM) growth modeling is used (Bliese \& Ployhart, 2002; Holcomb, Combs, Sirmon, \& Sexton, 2010). I perform the analysis in SAS using the PROC GLIMMIX procedure.

There are several advantages to using RCM growth modeling over other approaches of dealing with nested data. This allows firm-level control variables to be added to the model (Luke, 2004), such as the firm's line of business or presence of a competitive advantage. Although firm-level attributes could be aggregated for each state, aggregation can be problematic (Luke, 2004; Tabachnick \& Fidell, 2006). When aggregation is used, much of the variability for the dependent variable is lost, leading to the relationships between variables possibly to be substantially over- or under-estimated. Several previous studies in the management literature have used RCM to test both levels and time (Holcomb, Combs, Sirmon, \& Sexton, 2010; Short, Ketchen Jr, Bennett, \& du Toit, 2006). Short et al. (2006) examined how industry- and firm-level factors influence firm performance over time. Likewise, Holcomb et al. (2010) used RCM to examine how industry factors and growth strategies affect the performance of post-IPO firms. The model that I propose similarly contains three levels: within-firms (repeated measures over time), between-firms within-states, and between-states.

To test the hypotheses, I follow a model-building process similar to that recommended by Bliese \& Ployhart (2002). This first involves running an unconditional 
(null) model in which the variability in the dependent variable is partitioned to the different levels (time, firm, and state). Once the variance is partitioned among the levels, interclass correlations (ICCs) can be calculated to determine if the higher levels (firms and states) have a meaningful level of variability. The second step involves determining the fixed function for time. I test a linear, quadratic, and cubic trend to see what trend best describes employee growth in the new firms for the sampled period. The third step involves determining the variability in growth parameters; in other words, determining which of the growth parameters selected in step two should have random coefficients. Fourth, different error structures are compared, and the one that has the least amount of model misfit is selected. This is an important step because longitudinal data may have error structures that are correlated and heterogeneous. Finally, the independent variables of interest are added, and the analysis is performed so that the hypothesized relationships can be tested.

To allow for the comparison of model fit among models, full information maximum likelihood estimation (FIML) is used to estimate the fixed and random effects (O'Connell \& McCoach, 2007). All dichotomous variables are uncentered while the continuous variables are grand-mean centered.

The need for using RCM modeling and how many distinct levels are needed in the analysis can be assessed by calculating intraclass correlations (ICCs). Intraclass correlations are calculated to see how variance in the dependent variable can be explained by the different levels of analysis in the proposed multilevel model. I first run an unconditional (null) model in which the variability in the dependent variable is 
partitioned to the different levels. The intraclass correlations can be seen in Table 3.2. The intraclass correlations show how the variability in the dependent variable is explained by the three proposed levels: states, firm within states, and time points within firms. For states, it is around $0 \%$. This indicates that substantially none of the variance in firm employment is due to state differences. The intraclass correlation for firms is .7067 indicating that $70.67 \%$ of the variance in number of employees is at the firm level. The remaining $24.83 \%$ of the variance is within firms across time. The intraclass correlation for firms is substantial enough that failure to account for this clustering could inflate the standard errors of the parameter estimates (Kreft \& De Leeuw, 1998), indicating that random coefficient multilevel modeling is an appropriate analysis technique in this circumstance. However, because there is no variability among states with regard to firm employment, I do not model this level in the multi-level model. Thus, a model is used consisting of only two-levels: (1) firms and (2) time.

\section{Table 3.2 Intraclass Correlations}

\begin{tabular}{|l|c|c|}
\hline Covariance Parameter & Estimate & $\begin{array}{c}\text { Percentage of Total } \\
\text { Variance }\end{array}$ \\
\hline Among States & .0000 & $0 \%$ \\
\hline Among Firms within States & .7067 & $74 \%$ \\
\hline With Firms Over Time & .2483 & $26 \%$ \\
\hline Total & .9550 & \\
\hline
\end{tabular}

The next step is to determine the fixed function for time (Bliese \& Ployhart, 2002). In RCM growth modeling, there a number of possible growth trajectories that the dependent variable can take. Using theory and examining the data can help determine the 
proper growth trajectory that should be modeled. Common growth trajectories include linear, quadratic, and cubic. Linear trends are the simplest type of growth trajectory and involve growth that follows a straight line over time. The slope of the growth trajectory is constant over time. Modeling this type of growth involves only including a linear "wave" term in the level-1 model. A quadratic growth trend is one in which the slope (rate of growth) changes over time, leveling off and then becoming negative (Singer \& Willett, 2003). Modeling quadratic growth trends require including both a linear term as well as the linear term squared. A cubic growth trend is a higher- order growth trend that has two stationary points, such as a peak and a trough (Singer \& Willett, 2003). I examine the growth trajectory of the firm employment variable by the use of significance tests. The average growth trajectory for all firms included in the KFS survey can be seen in Figure 3.1

Figure 3.1: Average Firm Employment by Wave

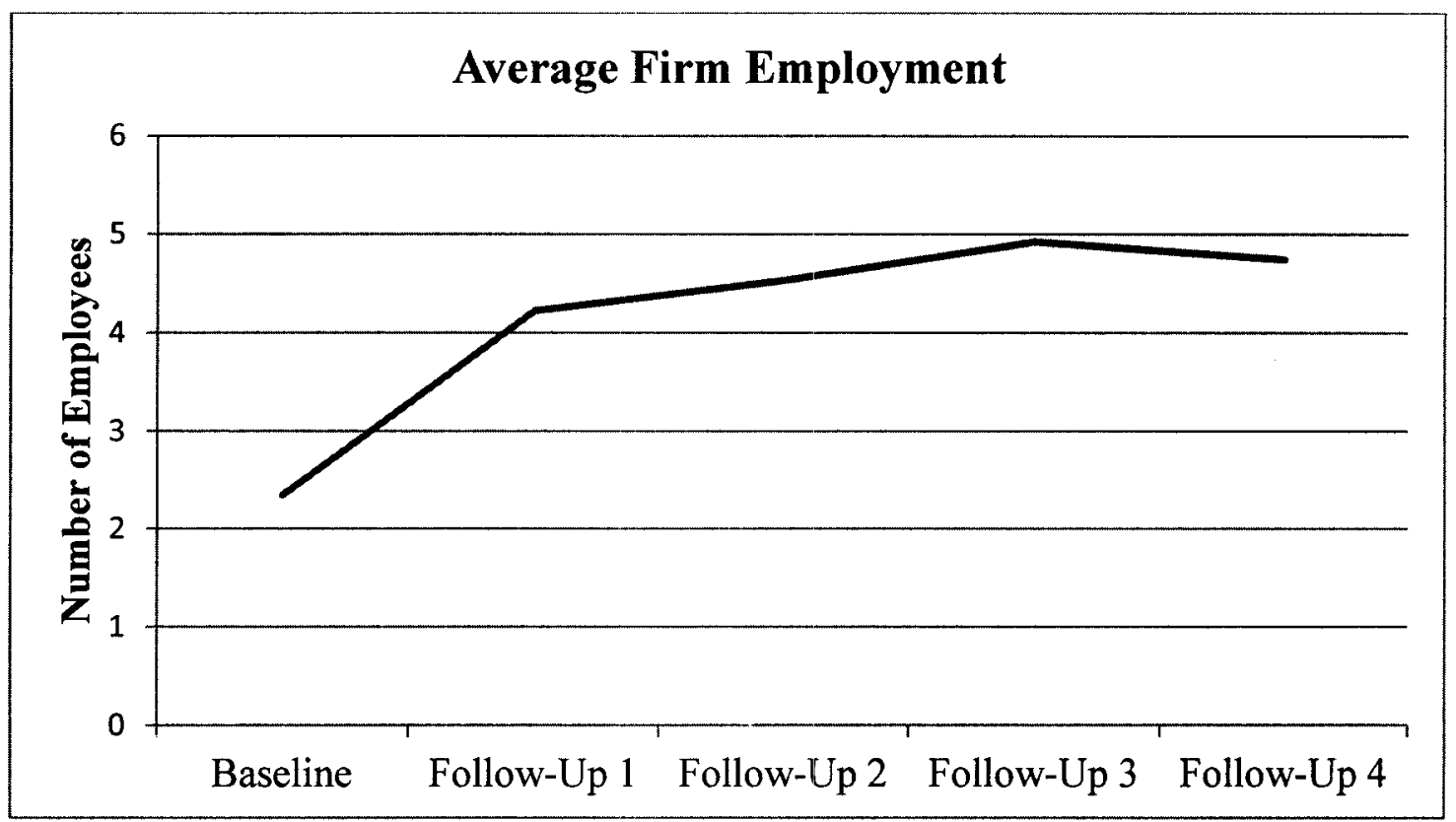


Visually, the growth trend appears to be approximately quadratic. I run the model as a linear, quadratic and cubic growth models. The results can be seen in Table 3.3. In the linear model, the linear term coefficient is .0891 is significantly different from zero ( $p$ $<.0001)$. In the quadratic model, both the coefficient for the linear term is .2767 and significantly different from zero $(p<.0001)$. The coefficient for the squared term is .0509 is also significantly different from zero $(p<.0001)$. In the cubic model, the linear term $(.3912 ; p<.0001)$ squared term $(-.1352 ; p<.0001)$ and cubed term $(.0144 ; p<$ $.0001)$ are significantly different from zero. Also, the cubic model has the lowest AIC $(18,201)$ and BIC $(18,242)$ of the three models. This indicates the cubic model offers the best fit. Thus, I model employment growth as a cubic growth curve.

Table 3.3: Growth Trends

\begin{tabular}{|l|c|c|c|c|c|c|}
\hline & \multicolumn{2}{|c|}{ Linear Model } & \multicolumn{2}{c|}{ Quadratic Model } & \multicolumn{2}{c|}{ Cubic Model } \\
\hline & Coefficient & $\boldsymbol{p}$-value & Coefficient & $\boldsymbol{p}$-value & Coefficient & $\boldsymbol{p}$-value \\
\hline Intercept & .5433 & $<.0001$ & .4733 & $<.0001$ & .4615 & $<.0001$ \\
\hline Linear & .0891 & $<.0001$ & .2767 & $<.0001$ & .3912 & $<.0001$ \\
\hline Quadratic & & & -.0509 & $<.0001$ &. .1353 & $<.0001$ \\
\hline Cubic & & & & & .01442 & $<.0001$ \\
\hline & & & & & & \\
\hline Fit Statistics & & & & & & \\
\hline $\begin{array}{c}-2 \text { Log } \\
\text { Likelihood }\end{array}$ & 18583.13 & & 18219.75 & & 18187.14 & \\
\hline $\begin{array}{c}\text { Generalized } \\
\text { Chi-Square }\end{array}$ & 1575.41 & & 1466.57 & & 1458.27 & \\
\hline $\begin{array}{c}\text { Gen. Chi- } \\
\text { Square/ DF }\end{array}$ & .17 & & .15 & & .15 & \\
\hline AIC & 18593.13 & & 18231.75 & & 18201.14 & \\
\hline BIC & 18622.58 & & 18267.10 & & 18242.37 & \\
\hline
\end{tabular}

In addition to determining what growth trajectories should be included in the model, there is also the decision to which growth terms should be allowed random 
coefficients. The linear, quadratic, and cubed terms are allowed to vary randomly by firm. However, the random effects of the quadratic and cubic term did not substantially improve fit. However, the fit is improved when the linear term was allowed to vary by firm, and hence it is allowed to vary by firm in the model.

The next step is to determine the error structure of the model. With longitudinal data, errors are likely to be correlated, and if this is not accounted for, significance test may be inaccurate (Bliese \& Ployhart, 2002). I ran models with two different types of error structures: autoregressive and unstructured. The results can be seen Table 3.4.

Comparing the autoregressive model to the previous model, which did not have the error structure modeled, the autoregressive model actually has worse fit. The ChiSquare increased from 1,458 to 1,534 , the AIC from 18,201 to 20,371, and BIC from 18,242 to 20,426 . Thus, the autoregressive model does not appear to be an improvement to not modeling the error structure. The unstructured model did have superior fit compared to the previous model without a modeled error structure. While the Chi-Square increased from 1,458 to 1,481 , the AIC decreased from 18,201 to 18,183 and BIC decreased from 18,242 to 18,230 . Thus, the unstructured error model is used. 
Table 3.4: Error Structures

\begin{tabular}{|l|c|c|l|l|l|l|}
\hline \multicolumn{3}{|c|}{ Autoregressive Model } & \multicolumn{3}{c|}{ Unstructured Model } \\
\hline Cov. Parameter & Estimate & SE & & Cov. Parameter & Estimate & SE \\
\hline Variance & .2870 & .2870 & & UN $(1,1)$ & .6043 & .0198 \\
\hline AR(1) Residual & .0794 & .0794 & & UN(2,1) & .0206 & .0044 \\
\hline Residual & .1621 & .1621 & & UN(2,2) & .0312 & .0019 \\
\hline & & & & Residual & .1565 & .0033 \\
\hline & & & & & & \\
\hline Fit Statistics & & & Fit Statistics & & \\
\hline $\begin{array}{c}\text {-2 Log } \\
\text { Likelihood }\end{array}$ & 20370.81 & & -2 Log Likelihood & 18166.70 & \\
\hline $\begin{array}{c}\text { Generalized } \\
\text { Chi-Square }\end{array}$ & 1533.60 & & $\begin{array}{l}\text { Generalized Chi- } \\
\text { Square }\end{array}$ & 1481.08 & \\
\hline $\begin{array}{c}\text { Gen. Chi- } \\
\text { Square/ DF }\end{array}$ & .16 & & $\begin{array}{l}\text { Gen. Chi-Square/ } \\
\text { DF }\end{array}$ & .16 & \\
\hline AIC & 20384.81 & & AIC & 18182.70 & \\
\hline AICC & 20384.82 & & AICC & 18182.71 & \\
\hline BIC & 20426.04 & & BIC & 18229.82 & \\
\hline
\end{tabular}

The final step is examining the hypothesized relationships. Originally, I planned to build a three-level model consisting of levels for time, firms, and states. However, because there was not a substantial amount of variance accounted for by the, it was dropped in favor a of a two-level model. Below, equations 1-3 display the equations associated with this model.

$$
\begin{aligned}
& \text { LNEMPLOYEES }_{\mathrm{ti}}=\pi_{0 \mathrm{i}}+\pi_{\mathrm{ii}} \text { WAVE }_{\mathrm{ti}}+\pi_{2} \text { WAVE }_{\mathrm{ti}}^{2}+\pi_{3} \text { WAVE }_{\mathrm{ti}}^{3}+ \\
& \pi_{4} \text { MINWAGE }_{\mathrm{ti}}+\pi_{5} \text { UNEMPLOYMENTRATE }_{\mathrm{ti}}+\pi_{6} \text { GDPPC }_{\mathrm{ti}}+ \\
& \pi_{7} \text { UNIONDENSITY }_{\mathrm{ti}}+\pi_{8} \text { UNINS }_{\mathrm{ti}}+e_{\mathrm{ti}} .
\end{aligned}
$$

LNEmployees $_{\mathrm{ti}}$ represents the natural log of the number of employees in time $t$ for firm i. $\pi_{0 \mathrm{i}}$ represents the initial employment level of firm $\mathrm{i}$ (the employment level of firm 
$\mathrm{i}$ in year 0 ). $\pi_{1 \mathrm{i}}$ represents the slope coefficient for variable WAVE $\mathrm{ti}_{\mathrm{t}}$, which is the slope of the change trajectory for firm $\mathrm{i}$, holding all else constant. The variable WAVE is coded 0 for 2004,1 for 2005,2 for 2006,3 for 2007 and 4 for 2008 . The term $\mathrm{WAVE}_{\mathrm{ti}}^{2}$ is the wave term squared and WAVE $^{3}{ }_{\mathrm{i}}$ is the linear term cubed, which together with the $\mathrm{WAVE}_{\mathrm{ti}}$ term models the cubic growth in employment among the new firms in the sample.

Also included in equation 1 are the state-level variables that vary across time. These include the minimum wage, union density, unemployment insurance index, gross domestic product per capita, and unemployment rate.

There are two level-two equations, one for the intercept term $\left(\pi_{0 i}\right)$ and one for the slope term for the linear growth term $\left(\pi_{l i}\right)$ of the level-1 equation.

(2) $\pi_{0 \mathrm{i}}=\beta_{00 \mathrm{k}}+\mathrm{r}_{0 \mathrm{i}}$

In equation $2, \beta_{00}$ represents the mean initial level of employment for firms. $\mathbf{r}_{0 i}$ represents how firm i deviates from this mean. This equation contains no predictors because the initial level of employment is not of interest. However, this value is allowed to vary for each firm because firms will have different starting levels of employment.

$$
\pi_{1 \mathrm{i}}=\beta_{10}+\beta_{11} \mathrm{CA} A_{\mathrm{i}}+\beta_{12} \mathrm{IN}_{\mathrm{i}}+\ldots \beta_{1 \mathrm{n}} \mathrm{IN}_{\mathrm{i}}+\mathrm{r}_{1 \mathrm{i}}
$$

In equation $3, \beta_{10}$ represents the mean annual employment growth, holding all else constant. This equation contains the firm-level variables that may predict a firm's employment growth, such as competitive advantage and industry dummy variables, and 
their corresponding slope values. These variables should be constant throughout time, thus are specified as time invariant using the value from time 0 .

\section{Results}

The descriptive statistics for all variables are displayed in Table 3.5. The correlations between these variables are displayed in Table 3.6.

Table 3.5: Descriptive Statistics

\begin{tabular}{|l|c|c|c|}
\hline Variable & N & Mean & $\begin{array}{c}\text { Standard } \\
\text { Deviation }\end{array}$ \\
\hline $\begin{array}{l}\text { LN(Number of } \\
\text { Employees) }\end{array}$ & 9,326 & .6907 & .9904 \\
\hline Industry 11 & 9,326 & .0167 & .1283 \\
\hline Industry 21-23 & 9,326 & .1488 & .3559 \\
\hline Industry 31-33 & 9,326 & .2824 & .4502 \\
\hline Industry 42-49 & 9,326 & .3073 & .4614 \\
\hline Industry 71 & 9,326 & .0727 & .2597 \\
\hline Industry 81 & 9,326 & .1720 & .3774 \\
\hline Competitive Advantage & 9,326 & .6471 & .4779 \\
\hline Unemployment Rate & 250 & 4.798 & 1.126 \\
\hline GDP Per Capita & 250 & 35,806 & 6,400 \\
\hline Union Density & 250 & 12.624 & 5.544 \\
\hline $\begin{array}{l}\text { Unemployment } \\
\text { Insurance Burden }\end{array}$ & 250 & 4.998 & .8961 \\
\hline $\begin{array}{l}\text { Minimum Wage } \\
\text { (Difference) }\end{array}$ & 250 & .4359 & .6805 \\
\hline
\end{tabular}


Table 3.6: Correlations

\begin{tabular}{|c|c|c|c|c|c|c|c|c|c|c|c|c|c|}
\hline Variable & 1 & 2 & 3 & 4 & 5 & 6 & 7 & 8 & 9 & 10 & 11 & 12 & 13 \\
\hline (1) LN(Employees) & 1 & & & & & & & & & & & & \\
\hline (2) Industryl1 & -0.02 & 1 & & & & & & & & & & & \\
\hline (3) Industry21-23 & 0.00 & $-0.06^{* * *}$ & 1 & & & & & & & & & & \\
\hline (4) Industry $31-33$ & $0.13^{* * *}$ & $-0.08^{* * *}$ & $-0.26^{* * *}$ & 1 & & & & & & & & & \\
\hline (5) Industry $42-49$ & $-0.05^{* * *}$ & $-0.08^{* * * *}$ & $-0.28^{* * *}$ & $-0.42^{* * *}$ & 1 & & & & & & & & \\
\hline (6) Industry71 & $0.09^{* * *}$ & $-0.04^{* * * *}$ & $-0.12^{* * * *}$ & $-.018^{* * * *}$ & $-0.19^{* * *}$ & 1 & & & & & & & \\
\hline (7) Industry81 & $-0.15^{* * *}$ & $-0.06^{* * *}$ & $-.019 * * *$ & $-.0 .29 * * *$ & $-0.30^{* * *}$ & $-0.13 * * *$ & 1 & & & & & & \\
\hline (8) Competitive Advantage & $0.07 * * *$ & 0.02 & $-0.10^{* * *}$ & $0.05^{* * *}$ & $0.03 * *$ & $0.04^{* * *}$ & $-0.04 * * *$ & $\mathrm{I}$ & & & & & \\
\hline (9) Unemployment Rate & $-0.07 * * *$ & $-0.06^{* * *}$ & 0.00 & $0.05^{* * *}$ & $-0.04^{* * *}$ & -0.02 & 0.02 & -0.02 & 1 & & & & \\
\hline (10) GDP Per Capita & 0.00 & -0.02 & -0.02 & $0.04^{* * *}$ & -0.02 & $0.03^{* *}$ & $.0 .03^{* *}$ & -0.02 & $-0.09 * * *$ & 1 & & & \\
\hline (11) Union Density & $-0.06 * * *$ & -0.02 & -0.01 & $0.04^{* * *}$ & $-0.04^{* * *}$ & 0.01 & 0.01 & $-0.03^{*}$ & $0.30^{* * *}$ & $0.49 * * *$ & 1 & & \\
\hline $\begin{array}{l}\text { (12) Unemployment } \\
\text { Insurance Burden }\end{array}$ & $0.03^{* *}$ & -0.02 & 0.02 & -0.01 & $0.02^{*}$ & -0.01 & -0.02 & 0.00 & $-0.16 * * *$ & $-0.34^{* * *}$ & $-0.51^{* * *}$ & 1 & \\
\hline (13) Minimum Wage & .0 .00 & -0.02 & $-0.03^{* *}$ & $0.04 * * *$ & -0.02 & 0.01 & 0.00 & $-0.03^{*}$ & $0.14^{* * *}$ & $0.51^{* * *}$ & $0.49^{* * * *}$ & $-0.22^{* * *}$ & 1 \\
\hline
\end{tabular}

Significance Level: *.05 **.01 $\quad * * * .001$ 
Next, I perform an analysis on two models: (1) control model containing only control variables, (2) and a model examining the hypothesized state-level effects.

The results for the control model are displayed in Table 3.7, and the results for the full model are in Table 3.8.

Table 3.7: Control Model

\begin{tabular}{|l|c|c|c|c|c|}
\hline Variable & Coefficient & SE & DF & $\boldsymbol{t}$-value & $\boldsymbol{p}$-value \\
\hline Intercept & .4686 & .01781 & 2630 & 26.31 & $<.0001$ \\
\hline Linear Trend & .3937 & .02568 & 6684 & 15.33 & $<.0001$ \\
\hline Quad Trend & -.1442 & .01578 & 6684 & -9.14 & $<.0001$ \\
\hline Cubic Trend & .01658 & .00283 & 6696 & 5.87 & $<.0001$ \\
\hline $\begin{array}{l}\text { Unemployment } \\
\text { Rate }\end{array}$ & -.01684 & .01209 & 6684 & -1.39 & .1635 \\
\hline GDP Per Capita & -.000001 & -.000003 & 6684 & -.58 & .5611 \\
\hline $\begin{array}{l}\text { Competitive } \\
\text { Advantage }\end{array}$ & -.00780 & .01092 & 6684 & -.71 & .4750 \\
\hline Industry 1 & -.03869 & .04025 & 6684 & -.96 & .3365 \\
\hline Industry 2 & .02102 & .01648 & 6684 & 1.28 & .2021 \\
\hline Industry 3 & .04081 & .01355 & 6684 & 3.01 & .0026 \\
\hline Industry 7 & -.00856 & .02150 & 6684 & -.40 & .6905 \\
\hline Industry 8 & -.03828 & .01563 & 6684 & -2.45 & .0143 \\
\hline & & & & & \\
\hline Fit Indices & & & & & \\
\hline P. Log Likelihood & 17924.29 & & & & \\
\hline Chi-Square & 1467.67 & & & & \\
\hline AIC & 17956.28 & & & & \\
\hline BIC & 18050.29 & & & & \\
\hline
\end{tabular}


Table 3.8: Full Model

\begin{tabular}{|l|c|c|c|c|c|}
\hline Variable & Coefficient & SE & DF & $\boldsymbol{t}$-value & $\boldsymbol{p}$-value \\
\hline Intercept & .4969 & .01792 & 2629 & 26.21 & $<.0001$ \\
\hline Linear & .3906 & .02576 & 6682 & 15.16 & $<.0001$ \\
\hline Quad & -.1409 & .01610 & 6682 & -8.75 & $<.0001$ \\
\hline Cubic & .01581 & .00291 & 6682 & 5.43 & $<.0001$ \\
\hline $\begin{array}{l}\text { Unemployment } \\
\text { Rate }\end{array}$ & -.00850 & .01278 & 6682 & -.66 & .5061 \\
\hline GDP Per Capita & .000002 & .000004 & 6682 & .57 & .5676 \\
\hline $\begin{array}{l}\text { Competitive } \\
\text { Advantage }\end{array}$ & -.00761 & .01092 & 6682 & -.70 & .4857 \\
\hline Industry 1 & -.03857 & .04027 & 6682 & -.96 & .3382 \\
\hline Industry 2 & .02095 & .01648 & 6682 & 1.27 & .2039 \\
\hline Industry 3 & .04076 & .01355 & 6682 & 3.01 & .0026 \\
\hline Industry 7 & -.00833 & .02151 & 6682 & -.39 & .6986 \\
\hline Industry 8 & -.03852 & .01564 & 6682 & -2.46 & .0138 \\
\hline Minimum Wage & -.00841 & .01580 & 6682 & -.53 & .5943 \\
\hline Union Density & -.00558 & .003258 & 6682 & -1.71 & .0869 \\
\hline $\begin{array}{l}\text { Unemployment } \\
\text { Insurance Burden }\end{array}$ & .00216 & .02197 & 6682 & .10 & .9216 \\
\hline & & & & & \\
\hline Fit Indices & & & & & \\
\hline P. Log Likelihood & 17920.11 & & & & \\
\hline Chi-Square & 1467.51 & & & & \\
\hline AIC & 17958.11 & & & & \\
\hline BIC & 18069.75 & & & & \\
\hline & & & & & \\
\hline & & & & & \\
\hline
\end{tabular}

In addition to the linear, quadratic and cubic trend variables, the control model includes industry dummy control variables, as well as controls for the unemployment rate, GDP per capita, and competitive advantage.

In the full model in Table 3.8, the results for the hypothesized relationships can be seen. In hypothesis 1 , a negative relationship is hypothesized between minimum wages and firm employment growth; however this hypothesis is not supported $(-.0084 ; p=$ .5943). In hypothesis 2 , a positive relationship is predicted between union density and 
employment growth. A marginally significant relationship is found, but in the opposite direction as hypothesized $(-.0056 ; p=.0869)$. The final hypothesis predicted that an unemployment insurance system that is costly and that penalizes firms for worker layoffs will lead to less employment growth. However, a significant relationship is not observed $(.0022 ; p=.9216)$

\section{Table 3.9: Results Summary}

\begin{tabular}{|l|l|l|}
\hline & \multicolumn{1}{|c|}{ Hypothesized Relationship } & Results \\
\hline H1 & $\begin{array}{l}\text { New firms operating in states with higher minimum wages } \\
\text { will have lower employment growth than new firms } \\
\text { operating in states with lower minimum wages. }\end{array}$ & Not supported \\
\hline H2 & $\begin{array}{l}\text { New firms operating in states with higher union densities } \\
\text { will have higher employment growth than new firms } \\
\text { operating in states with lower union densities. }\end{array}$ & Not supported \\
\hline H3 & $\begin{array}{l}\text { New firms operating in states with unemployment taxes } \\
\text { that are high and that penalize firms for worker layoffs will } \\
\text { have lower employment growth than new firms operating } \\
\text { in states with unemployment taxes that are low and that do } \\
\text { not penalized firms for worker layoffs. }\end{array}$ & Not supported \\
\hline
\end{tabular}

\subsection{DISCUSSION}

The hypothesis between minimum wages and firm employment did not receive support. There are several reasons why a relationship was not observed. First, there has been some research indicating that this relationship is not negative (Card and Krueger (1994) and there are some theoretically reasons proposed in the literature to why this might be (Brown \& Crossman, 2000; Kennan, 1995; Zavodny, 1998). Secondly, the sample consisted of new firms. One of the justifications of this study is that minimum wages may have different effects of new and small firms than incumbent and large firms. 
Perhaps, as suggested in some of the literature, small firms (which most of the new firms in the sample are) have the ability to adapt to changes in minimum wages in a more flexible manner than larger firms. Research suggest that they might be able to do this by hiring workers "off the books" and paying them a wage below the legal minimum wage (Arrowsmith et al., 2003), or cutting other benefits or vacation time (Brown \& Crossman, 2000).

The relationship between union density in states and new firm employment growth was negative and marginally significant, while a positive relationship was hypothesized. This is not particularly surprising however, as a theoretical case can be made for either direction. For example, much research has shown that unionization is associated with high employee wages (Duncan \& Stafford, 1980; Kwoka Jr, 1983; Stewart, 1990) and lower firm profitability (Voos and Mishel (1986; Hirsch, 1991; Menezes-Filho, 1997). Perhaps when new firms are in areas of high unionization, they are not immune from threats of unionization, especially as they grow larger. New firms may have to pay a higher wage when unioinizationzation is high. They may have to do this because their workers have become unionized, or to keep their workers from unionizing (Freeman, 1984). Also new firms in regions of high unionization may to pay a high wage in order to attract high-quality employees away from unionized jobs. Also, strong unionization may reflect other pro-labor institutions that raise the cost of hiring additional workers.

The unemployment insurance burden had a non-significant effect on employment growth, even though a negative relationship was hypothesized. This may be due to the 
fact that paying unemployment insurance premiums may ultimately be a small burden for new firms, and therefore may not have a noticeable effect on a firm's hiring behavior. Also, while certain aspects of unemployment insurance- such as how firing an employee influences the firm's premiums may deter a firm from hiring, it may also deter a firm from firing. The measure of the unemployment insurance burden is higher in states in which when a firm terminates an employee, they are charged a high unemployment insurance premium (Padgitt, 2009). Since such a penalty may deter both hiring and firing, there may ultimately be little net effect on firm employment growth.

\subsection{LIMITATIONS AND FUTURE RESEARCH}

There are several limitations to this analysis. First of all there is the possibility of alternative explanations accounting for the observed relationships. There are a large number of variables that vary by geographic regions and states that might be the underlying driver of employment growth. While some control variables are used in the analysis, many possible confounding variables may not be easily measured. Thus, they cannot be controlled for since they cannot be added as independent variables into the analysis.

Also, sample heterogeneity may have affected the results as well. A number of industries were excluded in which minimum wages, unionization, and the unemployment insurance burden should have little or no impact on hiring and firing decisions. These include firms in the real estate and leasing, finance and insurance, information, management of companies and enterprises, professional scientific and technical services, and health care and social assistance, and educational services industries. However, the 
sample may still include firms that are not particularly sensitive to minimum wages, unionization, or the unemployment insurance burden. Narrowing the sample to industries most affected by these labor market variables might lead to different results. For example, examining the effects of minimum wages only using food service firms would have made a much narrower sample, and perhaps a negative relationship would have been found. While the sample could have been made narrower, doing so has the undesirable effect of reducing our sample size, giving the analysis less power. Since any effect is likely to be small, having adequate power is essential. Furthermore, any finding of such a narrow sample is only valid for firms similar to those in the sample. Finding an effect in a very narrow sample may not be of particular importance.

Like many longitudinal studies, sample attrition is a problem in this study. In the baseline year, there were 2,662 firms in the sample, but this was reduced to 1,391 by the fourth follow-up wave. If this attrition is not random this could be problematic. It is reasonable to suspect that firms dropping out of the sample were disproportionally poor performers. The results may have been different had these firms been included in the analysis.

The data also suffer from the fact that we only observe firms that actually came into existence. The variables examined may reduce the likelihood of an entrepreneur starting a business to begin with. However, since the data do not include nascent entrepreneurs, this issue cannot be addressed.

I examined how labor market institutions influence employment growth in new firms. Most of the research on entrepreneurship and institutions has focused on how they 
influence the prevalence of self-employment well as the births and deaths of firms.

Little research has examined the impact that institutions have on firm growth, and this would be a fruitful are for future research. Formal institutions such as taxation, property rights, and sound money may influence the performance of the venture, such as how fast it grows.

\subsection{CONCLUSION}

New firms in the United States operate in labor markets with different characteristics; in particular they can differ dramatically in their labor market institutions. In this essay I examined the influence of state-level labor market factors, such as the level of unionization, minimum wage rates, and the structure of unemployment insurance, on employment in new firms. I made use of data from the Kauffman Firm Survey (KFS), a

longitudinal survey of new firms to test how labor market institutions affect employment growth in new firms. Unionization is found to have a negative effect on firm employee growth. I found no relationship between both minimum wages and the unemployment insurance burden and employee growth in new firms. 


\section{CHAPTER 4: THE IMPACT OF TAXES AND REGULATIONS ON NEW FIRM BIRTHS AND DEATHS IN STATE BORDER COUNTIES}

\subsection{INTRODUCTION}

Gartner (1988) and Vesper (1982) define entrepreneurship as the creation of a new organization. In addition to individual attributes of entrepreneurs, many environmental factors influence if, where, and what type of entrepreneurial activity occurs (Baumol, 1990; Shane, 2003). Many environmental factors influence the rate of new firm entry and exit in an economy. The size of the local market is a strong predictor of regional new firm formation (Davidsson, Lindmark, \& Olofsson, 1994). Exploiting opportunities requires that firms have certain levels of human capital and knowledge (Audretsch, Lehmann, \& Warning, 2005; Zucker, Darby, \& Brewer, 1998). A close proximity to universities and their associated knowledge spillovers increases firm birth rates (Audretsch et al., 2005; Kirchhoff, Newbert, Hasan, \& Armington, 2007). Labor markets with high levels of college graduates, income growth, and population growth also have high rates of new firm formation (Armington \& Acs, 2002). Institutions, or the rules of the game in an economy, play a role in predicting firm births and deaths as well. Individuals are more likely to start new firms in areas in which taxes are low (Kreft \& 
Sobel, 2005; Papke, 1991) and economic freedom is high (Campbell \& Rogers, 2007; Sobel, 2008).

Although informative, the existing research on how environments influence the births and deaths of firms has several limitations. Although some research focuses on how institutions influence firm births and deaths (Campbell \& Rogers, 2007; Ovaska \& Sobel, 2005; Sobel et al., 2007), to what degree these effects vary by industry is unknown. Certain types of firms, such as laundromats and retail outlets, provide services in which production and consumption occur simultaneously. Thus, they need to be located near the relevant customer base and may not have much choice in determining where to locate. However, many types of manufacturing firms have wide latitude in where to locate, and therefore, institutions may have a different impact on the births and deaths of these types of firms. Furthermore, a limitation of the current research is that although institutions have been found to influence firm births in U.S. states (Campbell \& Rogers, 2007; Kreft \& Sobel, 2005), U.S. states are heterogeneous with regards to demographics, human capital, and culture. Thus, these results may be due to confounding factors, some of which cannot be easily observed and measured.

This essay examines the following research question: Do taxes and regulations influence the birth and death rates of service and manufacturing firms in an economy? Counties located on state borders are used so that confounding variables such as culture and demographics can be controlled for. Measures used to predict firm births and deaths include taxation levels, government size, unionization, and minimum wages. In addition, I examine separately if the birth rates of manufacturing and services firms are influenced 
differently by the level of taxation. Policy makers have become increasingly concerned with encouraging entrepreneurship (Holtz-Eakin \& Rosen, 2004; Peterson, 1988). This essay should give policy makers some more refined ideas about how regulatory factors and taxation levels can influence new firm births and deaths.

This essay is structured as follows. First, I examine what factors influencing an individual's choice to enter and exit self-employment. Then, I develop hypotheses concerning how government size, taxation level, unionization, and minimum wages influence the birth and death of firms. Next, I test these hypotheses using firm birth and death data from the EBD (establishment births and deaths) tabulations. These tabulations consist of data on establishment births and deaths for each county in the U.S. by industry code from 1989-2005 (Plummer \& Headd, 2008). I merge these data with institutional measures at both the state- and county-level from the Economic Freedom of North America index and the U.S. Census of Governments. I test these hypotheses using a matching technique that matches contiguous counties located on state borders.

\subsection{OCCUPATIONAL CHOICE}

\section{Firm Deaths (Exit)}

Gimeno, Folta, Cooper, and Woo's (1997) model explains the decision to exit self-employment. In their model, the threshold level of performance is compared to the actual expected economic performance of the business to determine whether to continue the venture. The threshold level of performance is the minimum level of performance needed for a self-employed person to continue operating the firm and remaining self- 
employed (Gimeno et al., 1997). The threshold level of performance is a function of the opportunity cost associated with other forms of employment, the cost of switching occupations (from self-employment to the new occupation), and the difference in psychic income between continuing self-employment and alternative sources of employment. When the expected economic performance of a venture is higher than the threshold level of performance, an individual will continue to be self-employed. When the expected economic performance falls below the threshold level of performance, the firm is abandoned, and the individual leaves self-employment for alternative employment.

Following Gimeno et al., (1997), an individual will discontinue the business when the expected utility of operating the entrepreneurial venture $\left(U_{E}\right)$ is less than the utility of alternative employment $\left(\mathrm{U}_{\mathrm{A}}\right)$ minus the associated cost of switching from selfemployment of alternative employment $\left(\mathrm{SC}_{\mathrm{EA}}\right)$ :

$$
\mathrm{U}_{\mathrm{E}}<\left(\mathrm{U}_{\mathrm{A}}-\mathrm{SC}_{\mathrm{EA}}\right)
$$

The $U_{E}$ is determined by the expected economic performance of the venture $\left(E P_{E}\right)$ plus the psychic income that the individual obtains from operating the venture $\left(\mathrm{PI}_{\mathrm{E}}\right) . \mathrm{EP}_{\mathrm{E}}$ is a function of the entrepreneur's general human capital $\left(\mathbf{X}_{1}\right)$ and his or her human capital specific to the current firm $\left(\mathbf{X}_{2}\right)$. $\mathrm{PI}_{\mathrm{E}}$ is a function of a number of individual characteristics $\left(\mathbf{X}_{4}\right)$.

$$
\mathrm{U}_{\mathrm{E}}=\mathrm{EP}_{\mathrm{E}}\left(\mathbf{X}_{\mathbf{1}}, \mathbf{X}_{\mathbf{2}}\right)+\mathrm{PI}_{\mathrm{E}}\left(\mathbf{X}_{\mathbf{4}}\right)
$$

The expected utility of alternative employment $\left(\mathrm{U}_{\mathrm{A}}\right)$ is determined by the expected economic performance of alternative employment $\left(\mathrm{EP}_{\mathrm{A}}\right)$ plus the psychic 
income that the individual obtains from alternative employment $\left(\mathrm{PI}_{\mathrm{A}}\right) \cdot \mathrm{EP}_{\mathrm{A}}$ is a function of the entrepreneur's general human capital $\left(\mathbf{X}_{1}\right)$ and his or her human capital specific to alternative employment $\left(\mathbf{X}_{\mathbf{3}}\right) . \mathrm{PI}_{\mathrm{A}}$ is a function of a number of individual characteristics $\left(\mathbf{X}_{\mathbf{5}}\right)$.

$$
\mathrm{U}_{\mathrm{A}}=\mathrm{EP}_{\mathrm{A}}\left(\mathbf{X}_{\mathbf{1}}, \mathbf{X}_{\mathbf{3}}\right)+\mathrm{PI}_{\mathrm{A}}\left(\mathbf{X}_{\mathbf{5}}\right)
$$

Substituting (2) and (3) into (1) yields: (4)

$$
\left[\mathrm{EP}_{\mathrm{E}}\left(\mathbf{X}_{\mathbf{1}}, \mathbf{X}_{\mathbf{2}}\right)+\mathrm{PI}_{\mathrm{E}}\left(\mathbf{X}_{\mathbf{4}}\right)\right]<\left[\mathrm{EP}_{\mathrm{A}}\left(\mathbf{X}_{\mathbf{1}}, \mathbf{X}_{\mathbf{3}}\right)+\mathrm{PI}_{\mathrm{A}}\left(\mathbf{X}_{\mathbf{5}}\right)-\mathrm{SC}_{\mathrm{EA}}\right]
$$

Thus, an entrepreneur will close a firm when the expected utility gained from operating the venture becomes less than the expected utility of alternative employment minus the cost of switching from entreprneuership to alternative employment. The expected utility the entrepreneur recieves from the venture is a derived from both the economic performance of the venture as well as the psyhic income of operaing the venture. Likewise, the expected utility of alternative employment is due to both the economic performance and psychic income of alternative employment.

\section{Firm Births (Entry)}

Although the model developed by Gimeno et al. (1997) is used to predict whether a self-employed individual will switch to an alternative form of employment, it can be modified to predict if an individual who is currently engaged in alternative employment will switch into self-employment. Mathematically, an individual will discontinue wage employment and start a venture when the utility of alternative employment $\left(\mathrm{U}_{\mathrm{A}}\right)$ is less 
than the utility of self-employment $\left(\mathrm{U}_{\mathrm{E}}\right)$ minus the cost of switching from alternative employment to self-employment $\left(\mathrm{SC}_{\mathrm{AE}}\right)$ :

$$
\mathrm{U}_{\mathrm{A}}<\left(\mathrm{U}_{\mathrm{E}}-\mathrm{SC}_{\mathrm{AE}}\right)
$$

$\mathrm{U}_{\mathrm{A}}$ and $\mathrm{U}_{\mathrm{E}}$ are the same as above and $\mathrm{SC}_{\mathrm{AE}}$ is the switching cost from alternative to self-employment. This switching cost can include the cost of education and training needed to start a business, as well as the cost of buying assets for the new business. Often such costs may be sunk and not recoverable. For example, the cost of taking a course on how to write a business plan is a cost that might be incurred by someone switching from alternative employment to self-employment.

Equation 8 displays the combined equation:

$$
\left[\mathrm{EP}_{\mathrm{A}}\left(\mathbf{X}_{\mathbf{1}}, \mathbf{X}_{\mathbf{3}}\right)+\mathrm{PI}_{\mathrm{A}}\left(\mathbf{X}_{\mathbf{5}}\right)\right]<\left[\mathrm{EP}_{\mathrm{E}}\left(\mathbf{X}_{\mathbf{1}}, \mathbf{X}_{\mathbf{2}}\right)+\mathrm{PI}_{\mathrm{E}}\left(\mathbf{X}_{\mathbf{4}}\right)-\mathrm{SC}_{\mathrm{AE}}\right]
$$

The expected performance of the venture $\left(E P_{E}\right)$, the expected performance of alternative employment $\left(\mathrm{EP}_{\mathrm{A}}\right)$, and switching costs (both $\mathrm{SC}_{\mathrm{EA}}$ and $\mathrm{SC}_{\mathrm{AE}}$ ) are likely to be influenced by taxation levels, government size, and labor market regulations.

\subsection{TAXES, REGULATIONS, AND FIRM BIRTHS AND DEATHS}

North (1990) argues that a country or region accumulating factors of production has less influence on economic growth than the incentive structure or institutional

environment (Henrekson, 2007). Institutions set the "rules of the game" in an economy, determining incentives, reducing uncertainty, and influencing transaction costs (North, 1987). Institutions are often classified as formal or informal, with formal institutions 
being the rules that are developed by human beings, such as constitutions and statutory law (North, 1990; Williamson, 2000). Conversely, informal institutions include norms, customs, traditions, and religion (Williamson, 2000). Baumol (1990) applies institutional theory to the field of entrepreneurship, stating that formal institutions influence how entrepreneurs allocate their time and resources between productive, unproductive, and destructive activities. Productive entrepreneurship, according to Baumol \& Caves (1993) is "any activity that contributes directly or indirectly to net output of the economy or to the capacity to produce additional output" (p. 30). Activities such as engaging in frivolous lawsuits, avoiding taxes, and lobbying have been described as unproductive forms of entrepreneurship (Baumol, 1990; Foss \& Foss, 2002; Sauka \& Welter, 2007).

In the United States, the federalist system of government gives individual states a wide range of powers as specified in the U.S. constitution (US Const. amend. X), although there are a few powers that are explicitly prohibited (US Const. Art 1, sec 10). While institutions are often examined at the country level (Bjørnskov and Foss, 2007; Nystrom, 2008) formal institutions and factors influenced by institutions (such as unionization levels) often vary at lower levels of analysis, such as states (Karabegovic et al., 2005). This can be seen in the state differences in taxation levels, business regulations, total government spending, allocation of state funds, minimum wages, etc. I will specifically discuss how state difference in the level of taxation, government size, unionization, and minimum wages may influence the birth and death rate of businesses. 


\section{Taxation}

The impact of high taxes on entrepreneurship has been strongly debated.

Governments often levy a number of taxes against individuals and firms, and those taxes may influence the behavior of the individuals and firms. These include sales taxes, personal income taxes, business incomes taxes, inheritance and gift taxes, and user fees.

\section{Income Taxes}

Income taxes represent a substantial portion of all taxes paid by those operating a business. Business profits are often taxed at personal income tax rates (Carroll et al., 2001), reducing the expected returns from self-employment when taxes are high. This may discourage entry into self-employment, especially among high-income individuals when the tax system is highly progressive ${ }^{7}$ (Gentry \& Hubbard, 2005).

In addition to reducing incentives, high levels of taxation may discourage entry into self-employment by limiting the amount of self-funded assets available to prospective entrepreneurs. Entrepreneurs may suffer from liquidity constraints, meaning a lack of capital sometimes keep them from starting or expanding their business even in the presence of profitable opportunities (Holtz-Eakin et al., 1994; Johansson, 2000; Lindh \& Ohlsson, 1996). If those contemplating entering self-employment have difficulty obtaining financing from third parties, they may have to rely on their own limited funds. High taxes, especially those on income, may reduce the funds available to individuals wanting to start a business (Fölster, 2002).

\footnotetext{
${ }^{7}$ A progressive tax rate is one in which the tax rate becomes higher as the taxable base (often income) becomes higher. Thus, when an income tax is progressive, those with high incomes are subject to higher tax rates than those with lower incomes.
} 
Although high taxes may discourage entry into self-employment due to lower incentives and liquidity constraints, it has been suggested that high income taxes actually may encourage entry into self-employment for several reasons. The self-employed are typically allowed to deduct any business expenses when computing business income taxes, allowing some of their income to be sheltered from taxes (Lang, Nöhrbaß, \& Stahl, 1997; Schuetze, 2000). Wage earners have a more difficult time deducting job expenses relative to the self-employed because their deductions are subject to more limitations (Internal Revenue Service, 2010). When taxes are high, the business expense deduction may serve to encourage those with risky business ideas to start a new firm. Even if failure of the business does occur, those who are self-employed do not bear the full cost of the failure (Bruce \& Schuetze, 2004; Domar \& Musgrave, 1944) because some of the costs are recovered through the tax deduction.

High tax rates may encourage individuals to enter self-employment if they can more easily avoid paying all of the legally required taxes when they are self-employed (Bruce \& Schuetze, 2004). Firms in the U.S. are required to report the annual income earned by their employees to the Internal Revenue Service (IRS). However, selfemployed individuals have no third party reporting their income to the IRS (Schuetze, 2002). Furthermore, if a business conducts mainly cash transactions, the IRS may have a difficult time identifying and proving tax evasion. In addition to underreporting income, those who are self-employed may benefit by reporting personal expenses as business expenses so that they can deduct them from their income for tax purposes (Bruce \& Gurley-Calvez, 2008). Thus, although high taxes are likely to lower the expected return 
to self-employment, they may lower the expected returns to alternative employment even more. This may make entering self-employment the utility-maximizing choice.

Some studies have shown a positive relationship between income tax rates ${ }^{8}$ and rates of self-employment and entry into self-employment. See Table 4.1 for a summary of these studies. Schuetze (2000) found a positive relationship between the average income tax rates and self-employment rates in the U.S. and Canada. Parker (1996) uses co-integration analysis to test the long-run relationship between self-employment and its determinants and found a positive relationship between marginal income tax rates and self-employment. Long (1982) found that increasing the marginal income tax rate $10 \%$ is associated with a $6.4 \%$ increase in the self-employment ratio in metropolitan areas. Robson and Wren (1999) examined the relationship between both marginal and average tax rates and their impact on self-employment. While higher marginal income tax rates are associated with lower levels of self-employment, higher average income tax rates are associated with higher levels of self-employment. However, Gentry and Hubbard (2003) found that the Omnibus Budget Reconciliation Act of 1993 lowered the probability that those in upper-middle income households would become entrepreneurs by up to $20 \%$. This act raised the top marginal income tax rate from $36 \%$ to $39.6 \%$ (Auerbach \& Feenberg, 2000). For a comprehensive review of empirical findings concerning the relationship between income taxes and self-employment, see Bruce and Schuetze (2004).

\footnotetext{
${ }^{8}$ These studies make use of various measures of taxation, including average income tax rates, marginal income tax rates, marginal effective income tax rates, and overall tax burdens. The average income tax rate is the total amount of tax that an individual pays divided by their total income. The marginal income tax rate is the tax rate that an individual pays on their highest dollar of income. The effective marginal income tax rate is the marginal tax rate paid on the highest dollar of income, controlling for any decrease in transfer payments that the additional dollar of income causes. Measures of overall tax burdens, such as those from the Economic Freedom of North America index, combine several measures of taxation to develop a proxy of the overall tax burden.
} 
Table 4.1: Studies on Taxes and Firm Entry/Entrepreneurship

\begin{tabular}{|c|c|}
\hline Study & Findings \\
\hline $\begin{array}{l}\text { Wasylenko } \\
(1980)\end{array}$ & $\begin{array}{l}\text { Negative relationship between property taxes and firm location in } \\
\text { the manufacturing and wholesale industries in the Milwaukee } \\
\text { metropolitan area. }\end{array}$ \\
\hline Long (1982) & $\begin{array}{l}\text { Positive relationship between marginal income tax rate and self- } \\
\text { employment rate in SMSAs. }\end{array}$ \\
\hline Bartik (1985) & $\begin{array}{l}\text { Negative relationship between overall tax burden and new } \\
\text { business activity in U.S. states. }\end{array}$ \\
\hline Papke (1991) & $\begin{array}{l}\text { Negative relationship between marginal tax rate and firm births in } \\
\text { the publications, communication, and apparel industries in the } \\
\text { U.S. }\end{array}$ \\
\hline Parker (1996) & $\begin{array}{l}\text { Positive relationship between marginal tax rates and self- } \\
\text { employment rates in the United Kingdom. }\end{array}$ \\
\hline $\begin{array}{l}\text { Robson \& Wren } \\
\text { (1999) }\end{array}$ & $\begin{array}{l}\text { Negative relationship between marginal tax rates and self- } \\
\text { employment; positive relationship between average tax rates and } \\
\text { self-employment in } 15 \text { OECD countries. }\end{array}$ \\
\hline Schuetze $(2000)$ & $\begin{array}{l}\text { Positive relationship between average income tax rate and self- } \\
\text { employment rates in U.S. \& Canada. }\end{array}$ \\
\hline $\begin{array}{l}\text { Gentry \& } \\
\text { Hubbard (2000) }\end{array}$ & $\begin{array}{l}\text { Negative relationship between top marginal tax rate and } \\
\text { probability of upper-income individuals becoming self-employed } \\
\text { in the U.S. }\end{array}$ \\
\hline $\begin{array}{l}\text { Kreft \& Sobel } \\
(2005)\end{array}$ & $\begin{array}{l}\text { Negative relationship between overall tax burden and sole } \\
\text { proprietor growth rate in U.S. states. }\end{array}$ \\
\hline $\begin{array}{l}\text { McMullen, } \\
\text { Bagby, \& Palich } \\
(2008)\end{array}$ & $\begin{array}{l}\text { Negative relationship between overall tax burden and necessity- } \\
\text { motivated self-employment rates in GEM countries. }\end{array}$ \\
\hline
\end{tabular}




\section{Overall Tax Burden}

Although high income taxes may reduce the expected returns to self-employment, they may also reduce the returns to alternative employment even more. However, other forms of taxation do not typically allow special deductions for the self-employed and may even be more burdensome. For example, property taxes are levied on real estate and other assets, which often are owned by the self-employed for use in operating their business. However, those in alternative forms of employment may not have these assets (or at least not to the same extent), resulting in lower property taxes. Thus, relative to income tax rates, the overall tax burden in an economy may have a larger effect on the decision to become self-employed.

A number of studies found a negative relationship between taxation levels and the entry of new firms when using measures of taxation other than the income tax rate. Papke (1991) examined how state and local taxes influence the number of firm births using U.S. Census data. Five industries were examined: women's outerwear, household furniture, book printing, communication equipment, and electronic components. Although results varied by industry, a high marginal effective tax rate in a state was generally associated with fewer firm births in that state. Kreft and Sobel (2005) examine how institutions impact the sole proprietor growth rate from 1996 to 2000 in U.S. states, using the measure of overall tax burden from the Economic Freedom of North America (EFNA) index. They found a negative relationship between overall tax burdens and sole proprietor growth rates. Wasylenko (1980) examined how property taxes impact firm 
relocation. In manufacturing and wholesale trade firms, low property taxes are significant in determining firm relocation. However, the relationship is not significant for firms in the construction, retail trade, finance, and service industries. Bartik (1985a) examined how existing firms make decisions concerning where to locate a new manufacturing plant. High taxes were negatively associated with new business activity.

Thus, high overall tax burdens are likely to make the returns of self-employment lower than that returns of alternative employment. High taxes will deter individuals from switching into self-employment.

\section{H1: There is a negative relationship between the matched overall tax burden and the matched firm birth rate.}

\section{Taxation and Firm Deaths}

When taxes are high, firms will retain a smaller percentage of their pre-tax profits. When profits are low, they are more likely to fall below the threshold level of performance required by firm owner(s) to keep the firm operating (Gimeno et al., 1997). As a result, firm closure becomes more likely. High taxes also may lead to firm closure by lowering the amount of capital that the firm has for operations and investment. When taxes are high, firms are likely less profitable, giving them less money to invest in operating and expanding the business (Fölster, 2002). These reasons suggest that high levels of taxation may lead to high firm death rates.

However, there are other reasons that high levels of taxation may be associated with lower rates of firm deaths. The self-employed typically are allowed to deduct any 
business expenses on their tax return, allowing some of their income to be sheltered from taxes (Lang et al., 1997; Schuetze, 2000). If income taxes are high, then the ability to deduct expenses becomes more valuable, leading to greater self-employment. Another reason why higher tax rates may discourage firm closure is that individuals can more easily avoid paying all of the legally required taxes when they own a business (Bruce \& Schuetze, 2004). Although high taxes will decrease the expected return to selfemployment, they may decrease the expected return from alternative forms of employment even more. Thus, high taxes actually may lead to fewer firm deaths.

As discussed previously, a high level of taxation may serve as a barrier to entry to self-employment as well. Because high taxes are likely to deter entry, existing firms may face fewer competitors when taxes are high. A lack of competition allows firms currently operating to charge higher prices for the goods and services that they offer. This allows them to be more profitable. As this occurs, few self-employed individuals will close their businesses. Conversely, low levels of taxation may lead to more individuals entering self-employment (Aidis et al., 2009; Kreft \& Sobel, 2005). If this occurs, existing firms face more competition. As more firms compete for resources and customers, more firms are likely to fail (Hannan \& Carroll, 1992; Hannan \& Freeman, 1993).

\section{H2: There is a negative relationship between the matched overall tax burden and the matched firm death rate.}




\section{Government Size}

Governments are needed to provide certain goods and services in an economy. Public goods, such as defense, police protection, roads, court systems, and basic research, would likely be underinvested in without government action and funding (Cornes $\&$ Sandler, 1996; Nelson, 1959). When governments fail to provide these goods, entrepreneurship is likely to falter (Audretsch et al., 2005; Kirchhoff et al., 2007; Kreft \& Sobel, 2005). However, much debate exists about the impact that governments have on economic growth and entrepreneurship when the government goes beyond these basic functions and moves into providing private goods and redistributing wealth. Large governments typically provide extensive social safety nets and income redistribution, which may influence the attractiveness of entering into self-employment.

\section{Social Safety Nets}

Large governments often provide significant social safety nets to their citizens. Generous old-age pensions, medical care, disability payments, and unemployment insurance are some of the types of programs that large governments may provide to their citizens (Henrekson, 2005). Although much of the variation in entitlement programs is at the national level, significant variation exists among states in the level of benefits offered (Holcombe \& Lacombe, 2004b; Howard, 1999). For example, programs such as Temporary Assistance to Needy Families (TANF) ${ }^{9}$ are partially funded by the states with substantial differences in funding and benefit levels (McKinnish, 2007). In one sense, extensive social safety nets may serve to limit exposure to risk and, therefore, encourage

\footnotetext{
${ }^{9}$ TANF was formerly known as Aid to Families with Dependent Children (AFDC).
} 
additional risk-taking (Sinn, 1995, 1996). Starting a new firm possibly may be the kind of risky action that these safety nets stimulate.

However, these safety nets generally offer limited protection against business failure. This is because most social programs are providing assistance to low-income individuals with children and those who are unemployed (Henrekson, 2005). They generally do not provide protection for the costs that an entrepreneur may incur when their business fails. Furthermore, when states provide generous social safety nets, the state's safety net provides an incentive for individuals not to enter self-employment, and the returns to self-employment must be sufficiently high relative to the benefits provided by government programs (Henrekson, 2005). Thus, extensive social safety nets may provide another alternative to self-employment: unemployment.

As social safety nets become more comprehensive, individuals may be less likely to enter self-employment if they can earn an adequate return by exploiting the safety net. Individuals often enjoy free time (Hornberger \& Knauth, 1993) and thus obtain a high degree of psychic income from being unemployed. Even if individuals earn substantially less from exploiting the social safety net than from self-employment, they may still obtain more utility from exploiting the social safety net due to the high psychic income that unemployment offers. Ilmakunnas and Kanniainen (2000) found a negative relationship between the generosity of the social safety net, measured by the replacement ratio $^{10}$, and the level of entrepreneurship in OECD countries.

\footnotetext{
${ }^{10}$ The replacement ratio refers to the ratio of benefits received from not working (such as welfare payments and unemployment insurance payouts) and the amount of income received from working (Nickell, 1979).
} 


\section{Rent-Seeking Opportunities}

Large governments generally are involved in more aspects of the economy, increasing opportunities for rent-seeking (Goel \& Nelson, 1998; Scully, 1991). Rentseeking refers to the resource-wasting activities involved in competing for artificially contrived wealth transfers (Tollison, 1982). An individual or firm may engage in rentseeking by lobbying for regulations that thwart competition, by bribing public officials for monopoly rights, or by instigating frivolous litigation (Krueger, 1974; Murphy, Shleifer, \& Vishny, 1993). Rent-seeking activities are an alternative to self-employment; thus, as rent-seeking opportunities increase, the return of alternative employment increases. Fewer individuals will engage in entrepreneurial activities as more individuals are drawn into rent-seeking (Scully, 1991).

Furthermore, when a substantial amount of rent-seeking activities takes place, productive entrepreneurs are likely to be preyed upon. As an increasing number of individuals engage in rent-seeking activities and abandon productive entrepreneurship, those currently self-employed may be forced out of the market as their businesses are preyed upon by an increasing number of rent-seekers (Baland \& Francois, 2000; Murphy et al., 1993) and as returns to productive entrepreneurship fall (Acemoglu, 1995). Rentseekers may crowd out productive entrepreneurs in several ways, such as through frivolous lawsuits, wealth transfers, or lobbying for the passage of restrictive regulations that hurt competitor firms.

Thus, a large number of rent-seeking opportunities are likely to occur when governments grow leading to fewer individuals switching into self-employment. This is 
because: (1) rent-seeking opportunities provide a profitable alternative to selfemployment and (2) a high level of rent-seeking may lower the expected performance of self-employment, especially for owners of new firms.

\section{H3: There is a negative relationship between the matched state government size and the matched firm birth rate.}

\section{Government Size and Firm Deaths}

The size of the government may influence the decision of those currently selfemployed to exit or to remain self-employed. As governments grow larger, rent-seeking activities become more attractive (Goel \& Nelson, 1998). Rent-seeking activities are often directed at businesses, which may lower the expected returns to self-employment for some individuals. For example, rent-seekers may engage in pursuing frivolous litigation against medical doctors, causing some of them to exit self-employment and seek alternative employment. Even when rent-seekers are not successful in winning their case and making doctors pay damages, they may leave medical doctors with substantial legal fees (Dippolito et al., 2008).

However, operating businesses may also benefit from the large number of rentseeking opportunities that are likely to arise as governments become large. Existing firms may take advantage of these rent-seeking activities as a way to protect and expand their business (Krueger, 1974). Existing firms may have the necessary funding and associations needed to lobby effectively and to obtain favors from legislators and government leaders that new, less-organized entrants are likely to lack. Firms often 
engage in rent-seeking by lobbying for regulations that protect existing incumbent firms at the expense of new firms or potential startups (Dal Bo, 2006; Hardy, 2006; Stigler, 1971). During the development of the trucking industry, for example, some states limited the weight of trucks specifically on routes that competed with railroads. The shorter the average railroad haul distance, the lower the weight limit that some states allowed for freight trucks ${ }^{11}$ (Stigler, 1971). These regulations favored incumbent railroad firms over new entrants in the trucking industry.

It is likely that rent-seeking opportunities that large governments provide are more likely to be exploited by existing firms, increasing their financial performance. Thus, when governments are large, fewer individuals will exit self-employment for alternative forms of employment.

\section{H4: There is a negative relationship between the matched state government size and the matched firm death rate.}

\section{Minimum Wages and Firm Births}

High minimum wages increase labor costs for firms that require high amounts of low-skilled labor. In some cases, firms may be able to minimize the effects of minimum wages through increasing prices to increase revenue (Aaronson, 2001) or by hiring employees "off the books" so that they can pay a lower wage (Arrowsmith et al., 2003). However, when firms are in a competitive industry, they may not be able to raise prices. Also hiring employees "off the books" is illegal and typically not appealing to workers,

\footnotetext{
${ }^{11}$ Generally, trucks competed more with railroads on routes of relatively short distances. Railroads had more of an advantage over trucks on longer routes. Thus, it was thought that the longer the average railroad haul in a state, the less that railroads would lobby against trucking (Stigler, 1971).
} 
thus making it difficult to do. Some studies suggest that firms respond to high minimum wages by hiring fewer employees (Baker et al., 1999; Brown et al., 1982; Neumark \& Wascher, 2000).

High minimum wages and are likely to increase the labor cost of firms. This will make the expected returns of self-employment lower than they would be otherwise. Many new firms plan to hire employees fairly early in their life (Human \& Matthews, 2004). Thus, labor costs are likely considered when an individual is deciding whether to start a new firm. When a firm is first started, employees must be paid immediately even though the revenue those employees generate may not be realized until further in the future. This may be particularly burdensome for new firms because they are liquidityconstrained (Holtz-Eakin et al., 1994; Johansson, 2000) and often operate in competitive industries that have low profit margins (Jones et al., 2004; Ram et al., 2007). Additionally, new firms are typically small, and small firms often pay their employees relatively low wages (Brown \& Medoff, 1989; Idson \& Feaster, 1990; Morissette, 1993; Winter-Ebmer, 2001). Because small and new firms are likely to pay a larger percentage of their workers low wages, high minimum wages that increase the labor cost of lowwage workers may have a disproportionate impact on these types of firms.

H5: There is a negative relationship between the matched minimum wage and the matched firm birth rate. 


\section{Unionization and Firm Births}

High union densities in a region may be due to the types of industries in the region, to the culture (Singh, 2001), and to the laws that protect and encourage unionization (Moore, 1998). When union densities in a region are high, firms are more likely to be unionized. Unionized workers tend to get paid more than non-unionized workers (Duncan \& Stafford, 1980; Kwoka Jr, 1983; Stewart, 1990), making it more costly for unionized firms to operate. Several empirical studies support the idea that unionization can lead to decreased firm profitability (Hirsch, 1991; Menezes-Filho, 1997; Voos \& Mishel, 1986). New firms typically are not unionized however. Although unionization may generally lead to higher wages and lower profitability for most businesses, firms that are new and small are unlikely to be unionized even in a highly unionized region. Therefore, they may actually have an advantage over existing firms, since they will be able to obtain labor at a lower cost. Acs and Audretsch (1989) found that industries with high levels of unionization had higher levels of new firm entry than those with lower levels of unionization. Thus, high levels of unionization in a region may increase the returns of self-employment for owners of new firms entering the market.

H6: There is a positive relationship between the matched union density and the match firm birth rate. 


\section{Minimum Wages and Firm Deaths}

High minimum wages increase the labor costs of existing firms (Gregg, 2000). If the minimum wage rises above the marginal revenue that the employee(s) generate, then firm employment levels are likely to fall (Leonard, 2000). In addition to lowering firm employment levels, high minimum wages may even cause some firms to go out of business if they lower the expected performance of the firm below the threshold level. However, high minimum wages may also serve as an entry barrier (Kreft \& Sobel, 2005). If high minimum wages deter new firms from entering the market, competition will be limited. A lack of competition may allow existing firms to have more flexibility in setting prices, which may partially compensate for the higher labor cost. This will likely improve the economic performance of existing firms, leading to fewer self-employed individuals switching to alternative employment. Furthermore, many existing firms have been operating for some time, giving them a steady cash flow that can be used to pay for high labor costs if necessary, Waltman, McBride \& Camhout, (1998) found that high minimum wages are associated with lower business failure rates.

\section{H7: There is a negative relationship between the matched minimum wage and the matched firm death rate.}

\section{Unionization and Firm Deaths}

Unionized workers typically earn more money than equivalent non-unionized employees (Duncan \& Stafford, 1980; Kwoka Jr, 1983; Stewart, 1990), making it more expensive for unionized firms to operate. Unionization has been associated with lower 
firm profitability (Hirsch, 1991; Menezes-Filho, 1997; Voos \& Mishel, 1986). Although a high level of unionization in a state may negatively affect the profitability of firms (since they are more likely to be unionized), it is less likely to affect the profitability of new firms, which are unlikely to be unionized. High levels of unionization likely encourage new firm entry, and new firms that enter the market will tend to have lower labor cost than existing firms (Acs \& Audretsch, 1989). Thus, existing firms, at least those that are unionized, will be at a competitive disadvantage compared to newer firms. New firms will have the ability to still earn an adequate return while charging lower prices than existing unionized firms, decreasing the profitability of existing unionized firms. When returns to a business become low, owner(s) are more likely to discontinue operations because returns from the business may fall below the owner(s) opportunity costs (Gimeno, et al., 1997). Thus, high levels of unionization are likely to lead to a high rate of existing firms going out of business.

H8: There is a positive relationship between matched union density and the matched firm death rate.

\section{Nature of the Opportunity and Firm Births}

The impact that institutions have on firm entry is likely to vary depending on the nature of the opportunity, such as whether it involves performing a service or manufacturing a product. Services are unique from products in that the offering is intangible and that production and consumption often occur simultaneously (Carman \& Langeard, 1980; Erramilli \& Rao, 1993; Gohmann et al., 2008; Parasuraman, Zeithaml, \& Berry, 1985; Regan, 1963). Starting a firm that offers a service is likely to be much 
more location dependent than starting a firm to manufacture a product (Bowen \& Jones, 1986). Manufacturing firms are able to build their product in one location and sell their product in a different location (Keesing, 1983), while service firms often cannot.

\section{Taxation}

Individuals starting firms involved in manufacturing can start their firm in a location in which the institutional environment is most favorable, such as an environment with a relatively low tax burden (Bartik, 1985). However, service firms often do not have this luxury, as the geographical range in which the firm can be started is limited. For example, a prospective entrepreneur may discover that there is strong demand for pizzas but few pizzerias in Salisbury Massachusetts, while there is weak demand but many pizzerias nearby in Portsmouth, New Hampshire. New Hampshire may have a much lower tax burden, but the entrepreneur does not have the option of opening his or her pizzeria in Portsmouth unless he or she is willing to accept having few customers and/or charging a low price. However, a prospective entrepreneur who discovers that there is strong demand for a special type of surfboard among costal inhabitants could locate their manufacturing operations in a state with a low overall tax burden, such as South Dakota, and then transport the finished products to coastal areas where there is customer demand for them.

\section{H9: A high matched overall tax burden will have a stronger negative impact on the matched birth rate of manufacturing firms than service firms.}




\subsection{METHODS AND RESULTS}

\section{Sample}

The data used to test these hypotheses come from a set of custom tabulations from the U.S Census Bureau's Company Division. Known as the EBD (establishment births and deaths), these tabulations contain data on establishment births and deaths for each county in the U.S. from 1989-2005 (Plummer \& Headd, 2008). More specifically, they contain for each county in the U.S., the total single-unit, multi-unit, and total establishment firm births and deaths. I only use only data from 1992, 1997, and 2002 because of limited data availability of the independent variables.

In the EBD data, firm births and deaths are collected by industry and contain the firm's North American Industry Code System (NAICS) codes reported to five digits. An establishment is considered "born" in a year in which it first reports payroll. Conversely, an establishment death occurs when no payroll was reported in the current year but was reported sometime in the previous year. The U.S. Census Bureau defines an establishment as "a single physical location at which business is conducted or services or industrial operations are performed" (Plummer \& Headd, 2008: p. 8). The birth of a single-unit establishment represents the birth of a new venture; whereas, a multi-unit establishment birth represents the geographic expansion of an already existing firm (Plummer \& Headd, 2008). I only examine firm births and deaths from single-unit establishments. 


\section{Measures}

\section{Dependent Variables}

I perform the analysis with both matched firm births and firm deaths of singleestablishment firms. Although the EBD tabulations contain data on both single- and multi-unit establishments, the single-unit births and deaths are a better measure of entrepreneurship and not merely firm expansion. The ratio of firm births and deaths to the county's population are used as the dependent variables, representing the firm birth rate and the firm death rate for each county respectively. Therefore, county birth and death rates

Birth rate: (total county firm births $\mathrm{s}_{\mathrm{t}} /$ county population $_{\mathrm{t}}$ )

Death rate: (total county firm deaths $\mathrm{s}_{\mathrm{t}} /$ county population $_{\mathrm{t}}$ )

These rates are then matched to the rates of contiguous counties by dividing them by the average rate found in the contiguous counties (this is discussed in the "county matching technique" section).

\section{Independent Variables}

Measures of several state-level variables come from the Fraser Institute's Economic Freedom of North American (EFNA) index (Karabegovic et al., 2005). These measures have been used as measures of institutions in several previous studies (Campbell \& Rogers, 2007; Gohmann et al., 2008; Kreft \& Sobel, 2005; Sobel, 2008) and are available for all needed years. Developed by the Fraser Institute, EFNA index 
rates economic freedom for states/provinces in the U.S. and Canada. This index includes of three components: (1) size of government, (2) takings and discriminatory taxation, and (3) labor market freedom. Each of these components is consists of several individual measures, which can be seen in Figure 4.2. The labor market freedom is disaggregated into two of its measures: minimum wages as a percentage of GDP and union densities. All measures are transformed into a score ranging from 1-10, with 10 being consistent with high levels of economic freedom (and 1 associated with low levels). For example, states with a small government size have a score close to ten on that measure. The same is true with taxation level (takings and discriminatory taxation) as well as unionization and minimum wages.

To make the results easier to interpret, I reverse code these four variables by subtracting them from ten. This makes previously large values small and previously small values large. For example after the reverse coding, a high score on the size of government measure means that the state has a relatively large government, while a low score means it is relatively small. 
Table 4.2: Economic Freedom of North America Index Components

\begin{tabular}{|l|l|}
\hline Components & Measures \\
\hline \multirow{4}{*}{$\begin{array}{l}\text { Government } \\
\text { Size of }\end{array}$} & $\begin{array}{l}\text { 1A: General Consumption Expenditures by Government as } \\
\text { a Percentage of GDP }\end{array}$ \\
\cline { 2 - 2 } & 1B: Transfers and Subsidies as a Percentage of GDP \\
\cline { 2 - 2 } $\begin{array}{l}\text { 2. Takings and } \\
\text { Discriminatory }\end{array}$ & 2A: Social Security Payments as a Percentage of GDP \\
\cline { 2 - 2 } & $\begin{array}{l}\text { 2B: Top Marginal Income Tax Rate and the Threshold at } \\
\text { Which it Applies }\end{array}$ \\
\cline { 2 - 2 } & 2C: Indirect Tax Revenue as a Percentage of GDP \\
\cline { 2 - 2 } & 2D: Sales Tax Collected as a Percentage of GDP \\
\hline \multirow{3}{*}{ Freedom Labor Market } & 3A: Minimum Wage Legislation \\
\cline { 2 - 2 } & $\begin{array}{l}\text { 3B: Government Employment as a Percentage of Total State } \\
\text { Employment }\end{array}$ \\
\cline { 2 - 2 } & 3C: Union Density \\
\hline
\end{tabular}

\section{Control Variables}

Although the matching technique naturally controls for many confounding variables, I control for several county level variables: population density, county tax burden, median income and lagged birth and death rates.

The urbanization of the county is likely to have an effect on the level of entrepreneurship as well. Urban environments may offer more opportunities for entrepreneurship because they have access to larger markets and to suppliers leading to increased firm birth rates (Guesnier, 1994; Keeble \& Walker, 1994). In rural communities, agriculture may dominate the economy instead. Urbanization is measured by population density, which is calculated by taking the county's population divided by its area in square miles. 
In addition to state-level taxes, local-level taxes are likely to influence the location choice as well. Counties and cities often have their own tax rates, especially property tax rates. Therefore, high births of new firms in a border county could be due to favorable property taxes in the county compared to the neighboring county, not due to state-level factors. Thus, I also must control for the burden of taxes at the county-level. To do this, I use data from the U.S. Census Bureau's Census of Governments. The Census of Governments is taken every 5 years, and data are used from 1992, 1997 and 2002. The Census of Governments collects data from county governments, and data are collected on both expenditures and sources of revenue (U.S. Census Bureau, 2009b). For each county, data are available for the various sources of county revenue, such as income tax and property tax receipts.

I combine the Census of Governments revenue data with Census data on the population in each county (U.S. Census Bureau, 2011b) and the median income in each county (U.S. Census Bureau, 2011a). From this data, an estimate of the tax burden per capita for the county is calculated as follows:

County Tax Burden $=$ County Tax Per Capita/Median income

Median income is controlled for as well, since the wealth of an area is often a significant predictor of entrepreneurship levels (Parker and Robson, 2004; Noorderhaven and Thurik, Wennekers, and van Stel, 2004).

Finally, I control for lagged birth and death rates. For the analysis with the matched birth rate as the dependent variable, I control for matched lagged death rates. 
Likewise, for the dependent variable matched firm deaths, I included a lagged matched birth rate. The lags are three year lags.

\section{County Matching Technique}

I match counties with counties that are contiguous with one another and that lie across a state border. These counties will have access to similar customers, sources of human capital (Porter, 2000; Rauch, 1991), as well as a similar culture and climate (Holcombe \& Lacombe, 2004a). Thus, this method is a good way to control for factors, even those that are unobservable and immeasurable, that may vary based on location. This makes it more likely that any observed relationship between the state-level variables and firm births or deaths is not due to confounding factors. For these reasons, matching techniques have been used in a number of studies in the economics literature (Bronars \& Lott, 1998; Card, 1992; Dube, Lester, \& Reich, 2007; Holcombe \& Lacombe, 2004a, b; Holmes, 1998).

The data on contiguous counties come from the 1991 Contiguous County file from the U.S. Census. This file contains data on contiguous counties for every county in the U.S. (Inter-University Consortium for Political and Social Research, 1991). The file contains each pair of counties that are contiguous to one another, as well as a code that represents in what way the two counties are contiguous. In this essay, I consider counties contiguous if they meet any of the following three conditions: (1) they share a border, (2) they lie across a body of water but are connected by a bridge of ferry, or (3) they share a corner. I eliminate county pairs in which both counties are in the same state, only leaving pairs of contiguous counties that are on different sides of a state border. Counties vary 
drastically by their area. San Bernardino County, California, is 20,052 square miles in size (U.S. Census Bureau, 2009a), larger than nine U.S. states, all which contain multiple counties. The state of Maryland is only 9,774 square miles in size, yet contains 24 individual counties and equivalents (U.S. Census Bureau, 2009c). Typically, counties in the Western U.S. are far larger than counties in the Eastern U.S. Therefore, any border effect is likely to be less pronounced in large counties, which may stretch far from the border (Holmes, 1998). However, the county size that is "too large" has not been well defined in the literature. Holmes (1998) handles this issue by ignoring states located in the western U.S. which are likely to have larger counties. Others have simply performed the analysis using all available counties, such as Holcombe and Lacombe (2004a, b). To account for this issue, the main analysis is performed by eliminating counties that have a land area of over 1,200 square miles. Eliminating these extremely large counties leaves 952 counties.

Because data from the Census of Governments are only available for 1992, 1997 , and 2002, I construct three panels that coincide with these years. However, the variables are not used in their raw form; they are matched with those of bordering counties. I perform the analysis similarly to that of Holcombe and Lacombe (Holcombe \& Lacombe, 2004a, b). For example, I construct the dependent variable, matched firm birth rate, by taking the new firm birth rate in counties located on state borders and dividing that rate by the average birth rate of the counties that are contiguous to it but that are located in another state. Often, a county shares a border with at least two counties in the neighboring state, thus the average birth rates of these counties must be calculated and 
used in the denominator of the matched birth rate formula. The formula can be written as:

$$
M B R_{i}=B R_{i} /\left[(1 / n) \sum_{j=1}^{n} B R_{j}\right]
$$

$\mathrm{MBR}_{\mathrm{i}}$ is the matched birth rate for county $i . \mathrm{BR}_{\mathrm{i}}$ is the birth rate of new firms in border county $i$, and $\mathrm{BR}_{\mathrm{j}}$ represents the birth rates of new firms in the contiguous counties on the other side of the state border (but all within the same state). $n$ represents the number of contiguous counties on the other side of the state border. $\mathrm{MBR}_{\mathrm{i}}$, the matched birth rate for county $i$, is obtained by taking the birth rate of new firms in county $i$ and dividing this value by the average birth rate of contiguous counties that are on the other side of the state border. For example, let us say that county $i$ is in state $Y$ and county $i$ borders counties $j 1$ and $j 2$, which are located in state $Z$. Given that the firm birth rate in county $i=.06$, county $j l=.08$ and county $j 2=.10$, then the matched birth rate for county $i$ would be $=(.06 /((1 / 2) /(.08+.10))=(.06 / .09)=.667$. The matched birth rate represents the county's new firm birth rate as a percentage of the average new firm birth rate of contiguous counties across the state border.

Counties that share borders with counties in two different states are included in the analysis twice so that the variables associated with both states can be examined separately. This leads to a small increase in the sample size from 952 to1101. In addition to performing this matching for total new firm births in counties, 
I also perform the analysis separately for both the birth rate of manufacturing firms and the birth rate of service firms in order to test hypothesis 9.

$$
M D R_{i}=D R_{i} /\left[(1 / n) \sum_{j=1}^{n} D R_{j}\right]
$$

Formula 2 is used to test the hypotheses predicting firm deaths. Formula 2 is identical to formula 1 , except that it represents death rates. $\mathrm{MDR}_{\mathrm{i}}$ is the matched death rate for county $i . \mathrm{DR}_{\mathrm{i}}$ is the death rate of new firms in border county $i$, and $\mathrm{DR}_{\mathrm{j}}$ represents the death rates of new firms in the contiguous counties on the other side of the state border (all within the same state). $n$ represents the number of contiguous counties on the other side of the state border. $\mathrm{MDR}_{\mathrm{i}}$, the matched death rate for county $i$, is obtained by taking the death rate of firms in county $i$ and dividing this value by the average death rate of contiguous counties that are on the other side of the state border. All independent variables, including control variables, are matched in the same manner.

\section{Statistical Technique}

I predict county-level firm birth and death rates using both county- and state-level predictors. The matching of border counties creates a unique nesting problem: counties located on a state border are likely to have similar birth and death rate to other counties in the state because firms in those counties will have similar tax rates and regulations. For example, a county located along the Kentucky border with Indiana (such as Jefferson County) is likely to have more similar firm birth and death rates with another Kentucky counties along the Indiana border (such as Oldham County) than a county located on the 
Kentucky-Tennessee border (such as Wayne County). Thus, the border counties on a particular state line are nested within a border area. Border areas are counties within a state that share a common border with a certain adjacent states. There are 174 border areas in the sample with an average of 4.99 counties in each with a standard deviation of 3.54 .

Additionally, border regions are themselves nested within states. The state of Kentucky, for example, shares borders with Illinois, Indiana, Ohio, West Virginia, Virginia, Tennessee, and Missouri. If a state has favorable institutions conductive to the creation of new firms, that state is likely to have high relative new firm birth rates in all border areas. Therefore, the model is developed as a three-level model. An example of this can be seen in Figure 4.2, which shows an example of Jefferson County, Kentucky. Jefferson County is nested within the Kentucky-Indiana border area, which itself is nested within the state of Kentucky. There are 45 states included in the sample. 
Figure 4.1: Nested Data Example: Jeffersonville County Kentucky

\section{State (level 3): Kentucky}

\section{Independent Variables: None}

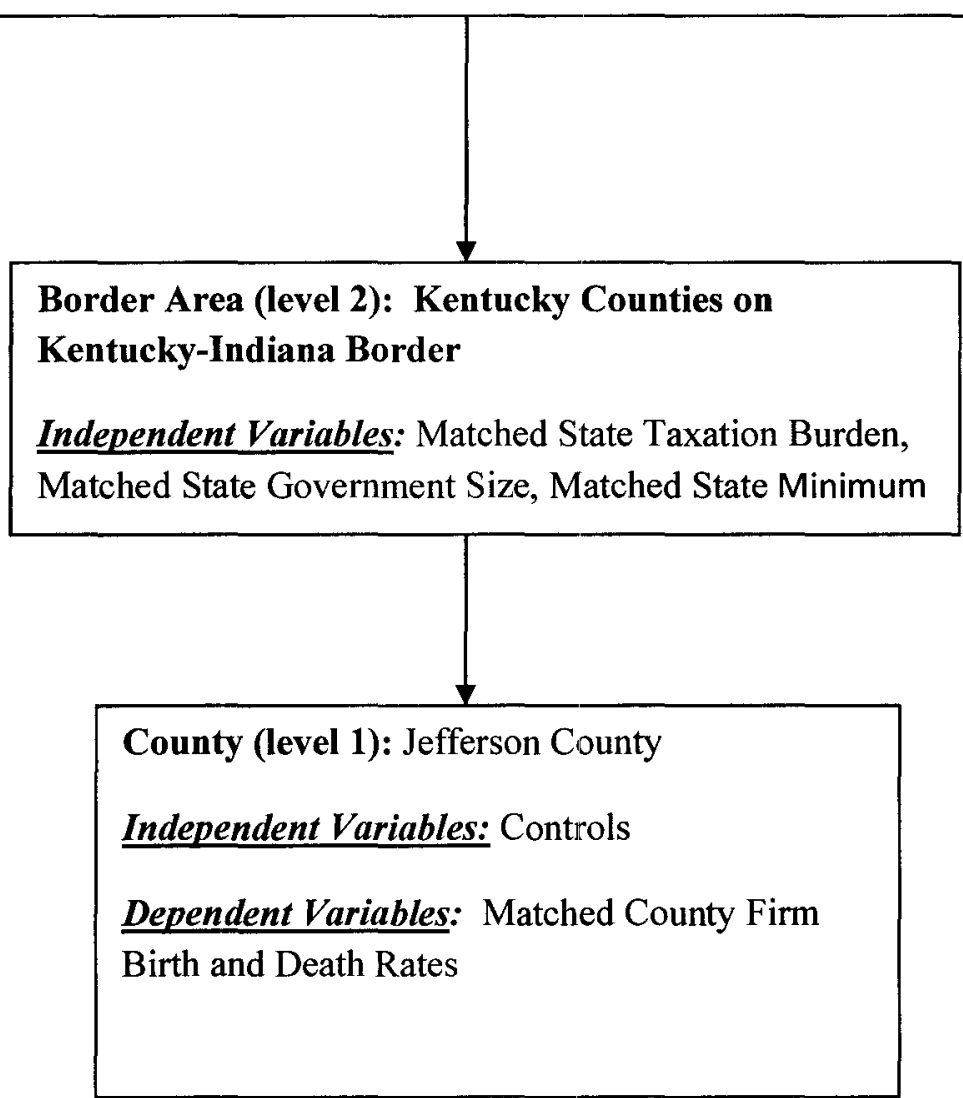


I perform multilevel modeling using the lme procedure in $\mathrm{R}$ to test the proposed hypotheses and to account for the multilevel structure of the data. With this type of analysis, higher-level independent variables can be used to predict county-level outcomes and different intercepts can be fitted for each border area as well as each state. To test the developed hypotheses, I follow a model-building process like that recommended by Raudenbush and Bryk (2002). This first involves running an unconditional (null) model in which the variability in the dependent variable is partitioned into the different levels (i.e., county, border area, state). Once the variance is partitioned among the levels, interclass correlations (ICCs) can be calculated to determine if the higher levels (border area and state) have a meaningful level of variability. To allow for the comparison of model fit among models, full information maximum likelihood estimation (FIML) is used to estimate fixed and random effects (O'Connell \& McCoach, 2007).

The county-level equation is the level-1 equation because counties are the lowest level of analysis. The level-1 (county-level) equation is displayed below:

$$
\begin{aligned}
& \mathrm{Y}_{\mathrm{ijk}}=\pi_{0 \mathrm{jk}}+\pi_{1} \text { PopulationDensity }_{\mathrm{i}}+\pi_{2} \text { CountyTaxBurden }_{\mathrm{i}}+\pi_{3} \text { MedianIncome }_{\mathrm{i}}+ \\
& \pi_{4} \text { LaggedRate }_{\mathrm{i}}+\mathrm{e}_{\mathrm{ijk}} \\
& \text { In equation (1), } \mathrm{Y}_{\mathrm{ijk}} \text { is the matched birth rate (or death rate) for county } i . \pi_{0 \mathrm{jk}}
\end{aligned}
$$
represents the matched intercept term for border area $j . \mathrm{Y}_{\mathrm{ijk}}$ is predicted by county-level measures of population density, county tax burden, median income, and lagged rate (birth or death). In this analysis, I allow the intercept term, $\pi_{0 \mathrm{jk}}$, to vary based upon the border area in which the county is located. However, the slope coefficients for the level-1 equation are not allowed to vary based upon the county. Thus, this simplifies the model, 
leaving only one level-2 equation which uses matched state-level variables (which are unique to each border area) to predict the intercept term, $\pi_{0 \mathrm{jk}}$.

$$
\begin{aligned}
& \pi_{0 \mathrm{jk}}=\beta_{00 \mathrm{k}}+\beta_{01 \mathrm{j}} \text { SizeofGovernment }_{\mathrm{j}}+\beta_{02 \mathrm{j}} \text { TaxBurden }_{\mathrm{j}}+\beta_{03 \mathrm{j}} \text { Unionization }_{\mathrm{j}}+ \\
& \beta_{04 \mathrm{j}} \text { MinimumWage }_{\mathrm{j}}+\mathrm{r}_{0 \mathrm{jk}}
\end{aligned}
$$

Equation 2 shows how $\pi_{0 \mathrm{jk}}$ is determined. $\beta_{00 \mathrm{k}}$ represents the intercept term, which I allow to vary by state. This is the mean matched birth (or death) rate for the state that the border lies in, all else held constant. $\pi_{0 \mathrm{jk}}$ is predicted by the matched size of government, tax burden, unionization, and minimum wages.

$$
\beta_{00 \mathrm{k}}=\gamma_{000}+\mu_{00 \mathrm{k}}
$$

As represented in equation $3, \beta_{00 k}$ is allowed to vary based upon the state. Thus, $\gamma_{000}$ represents the mean birth (or death) rate for each state, while ${ }_{\mu 00 k}$ represents the variation of border area $k$ from the state mean.

\section{Results}

The descriptive statistics for all the variables used in the analysis and their correlation are displayed in Table 4.3. Note that these variables are in the form of matched rates. 
Table 4.3: Correlations and Descriptive Statistics

\begin{tabular}{|c|c|c|c|c|c|c|c|c|c|c|c|}
\hline Variable & 1 & 2 & 3 & 4 & 5 & 6 & 7 & 8 & 9 & 10 & 11 \\
\hline (1) Birth Rate Ratio & 1.00 & & & & & & & & & & \\
\hline (2) Death Rate Ratio & $0.57 * * *$ & 1.00 & & & & & & & & & \\
\hline (3) Lagged Birth Rate Ratio & $0.56^{* * *}$ & $0.56^{* * *}$ & 1.00 & & & & & & & & \\
\hline (4) Lagged Death Rate Ratio & $0.53^{* * *}$ & $0.5^{* * *}$ & $0.52^{* * *}$ & 1.00 & & & & & & & \\
\hline (5) County Tax Burden & $0.15^{* \div *}$ & $0.14^{* * *}$ & $0.14^{* * *}$ & $0.14 * * *$ & 1.00 & & & & & & \\
\hline (6) Government Size & 0.02 & 0.01 & 0.02 & 0.01 & $-0.14^{* * *}$ & 1.00 & & & & & \\
\hline (7) Tax Burden & $-0.08 * * *$ & $-0.05^{* *}$ & $-0.06^{* * *}$ & -0.02 & $-0.09^{* * *}$ & $0.66^{* * *}$ & 1.00 & & & & \\
\hline (8) Median Income & $0.24^{* * *}$ & $0.19 * * *$ & $0.25^{* * *}$ & $0.15^{* * *}$ & $0.21 * * *$ & $-0.13^{* * *}$ & $-0.1^{* * *}$ & 1.00 & & & \\
\hline (9) Minimum Wage & 0.03 & 0.03 & $0.06^{* * *}$ & $0.03^{*}$ & $-0.16^{* * *}$ & $0.84 * * *$ & $0.55^{* * *}$ & $-0.14^{* * *}$ & 1.00 & & \\
\hline (10) Population Density & $0.13^{* * *}$ & $0.12^{* * *}$ & $0.13^{* * *}$ & $0.09^{* * *}$ & $0.14^{* * *}$ & 0.01 & -0.02 & $0.07 * * *$ & $-0.04^{*}$ & 1.00 & \\
\hline (11) Unionization & $0.11^{* * *}$ & $-0.12^{* * *}$ & $-0.12^{* * *}$ & $-0.09^{* * *}$ & $0.14^{* * *}$ & $-0.22 * * *$ & 0.00 & $-0.12^{* * *}$ & $-0.17^{* * *}$ & 0.01 & 1.00 \\
\hline Mean & 1.0526 & 1.0454 & 1.0510 & 1.0405 & 1.1703 & 1.06573 & 1.0224 & 1.0180 & 1.0614 & 1.8613 & 1.1413 \\
\hline Standard Deviaton & 0.4595 & 0.4062 & 0.4412 & 0.4151 & 0.8835 & 0.4163 & 0.2062 & 0.1991 & 0.3599 & 4.1885 & 0.6517 \\
\hline
\end{tabular}

Significance Level: * $.05 \quad * * .01 \quad * * * .001$ 
The need for using RCM modeling can be partially assessed by calculating intraclass correlations (ICCs). Intraclass correlations are calculated to see how variance in the dependent variable can be explained by the different levels of analysis in the proposed multilevel model. I first ran an unconditional (null) model in which the variability in the dependent variable is partitioned to the different levels (county, border area, and states). The intra-class correlations for both of the dependent variables can be seen in Table 4.4. The intra-class correlations show how the variability in the dependent variables is explained by the three proposed levels: counties, border areas, and states.

Table 4.4: Random Effects and Intraclass Correlations

\begin{tabular}{|l|c|c|c|c|}
\hline & Birth Rate & & Death Rate & \\
\hline & Variance & Percentage & Variance & Percentage \\
\hline State & 0.0078 & $3.59 \%$ & 0.004 & $2.36 \%$ \\
\hline Border Group & 0.0326 & $14.97 \%$ & 0.0194 & $11.52 \%$ \\
\hline County & 0.1773 & $81.43 \%$ & 0.1453 & $86.12 \%$ \\
\hline Total & 0.2177 & & 0.1688 & \\
\hline
\end{tabular}

For the birth rates, about $3.59 \%$ of the variation is due to state differences, while $14.97 \%$ is due to differences between border areas. For the death rates, $2.36 \%$ of the variation is attributes to state differences, $11.52 \%$ is due to differences between border areas. When observations are clustered in higher level units, the standard errors can be inflated, and Type I errors are more likely to occur (Kreft \& De Leeuw, 1998). Only a small percentage of the variance in birth and death rates are at the state level $(3.59 \%$ and 2.36\%). However, Roberts (2007) found that "group dependence may still exist depending on the nature of the covariates introduced into the model" (p. 15) when an 
intraclass correlation is close to zero. Thus, I kept the random state-level intercepts in the model despite the relatively small percentage of variation attributed to states.

Next, I estimated a control model for both the matched birth and death rate differences as dependent variables. These can be seen in Tables 4.5 and Table 4.6. Then I estimated a full model which contains both the control and hypothesized models. The results can be seen in Table 4.7 and Table 4.8.

Table 4.5: Control Model: Matched Birth Rate

\begin{tabular}{|l|c|c|c|c|}
\hline Variable & Coefficient & SE & t-value & $p$-value \\
\hline Intercept & .0669 & .0434 & 1.54 & .1299 \\
\hline County Tax Burden & .0451 & .0090 & 5.03 & $<.0001$ \\
\hline Median Income & .4173 & .0380 & 10.99 & $<.0001$ \\
\hline Death Rate Lagged & .4719 & .0164 & 28.72 & $<.0001$ \\
\hline Population Density & .0080 & .0017 & 4.60 & $<.0001$ \\
\hline Year 1997 & -.0058 & .0153 & -.38 & .7045 \\
\hline Year 2002 & .0041 & .0153 & .27 & .7872 \\
\hline & & & & \\
\hline AIC & 2730.1 & & Observations & 3249 \\
\hline BIC & 2790.9 & & Border Areas & 174 \\
\hline & & & States & 45 \\
\hline
\end{tabular}


Table 4.6: Control Model: Matched Death Rate

\begin{tabular}{|l|c|c|c|c|}
\hline Variable & Coefficient & SE & $\boldsymbol{t}$-value & $\boldsymbol{p}$-value \\
\hline Intercept & .4196 & .0357 & 11.76 & $<.0001$ \\
\hline County Tax Burden & .0298 & .0076 & 3.91 & $<.0001$ \\
\hline Median Income & .0952 & .0338 & 2.81 & .0049 \\
\hline Birth Rate Lagged & .4624 & .0141 & 32.69 & $<.0001$ \\
\hline Population Density & 0053 & .0015 & 3.50 & .0005 \\
\hline Year 1997 & -.0054 & .0139 & -.39 & .6985 \\
\hline Year 2002 & -.0069 & .0139 & -.50 & .6186 \\
\hline & & & & \\
\hline AIC & 1993.2 & & Observations & 3249 \\
\hline BIC & 2054.1 & & Border Areas & 174 \\
\hline & & & States & 45 \\
\hline
\end{tabular}

Table 4.7: Full Model: Matched Birth Rate

\begin{tabular}{|l|c|c|c|c|}
\hline Variable & Coefficient & SE & $\boldsymbol{t}$-value & $\boldsymbol{p}$-value \\
\hline Intercept & .2806 & .0728 & 3.85 & $<.0001$ \\
\hline County Tax Burden & .0472 & .0090 & 5.27 & $<.0001$ \\
\hline Median Income & .4057 & .0380 & 10.66 & $<.0001$ \\
\hline Death Rate Lagged & .4725 & .0164 & 28.76 & $<.0001$ \\
\hline Population Density & .0078 & .0017 & 4.54 & $<.0001$ \\
\hline Year 1997 & -.0070 & .0154 & -.45 & .6491 \\
\hline Year 2002 & -.0054 & .0154 & .35 & .7257 \\
\hline Government Size & .0460 & .0526 & .88 & .3814 \\
\hline Taxation Level & -.2680 & .0657 & -4.08 & $<.0001$ \\
\hline Union Density & -.0254 & .0157 & -1.62 & .1045 \\
\hline Minimum Wage & .0483 & .0512 & .94 & .3453 \\
\hline & & & & \\
\hline AIC & 2716.3 & & Observations & 3249 \\
\hline BIC & 2801.5 & & Border Areas & 174 \\
\hline & & & States & 45 \\
\hline
\end{tabular}


Table 4.8: Full Model: Matched Death Rate

\begin{tabular}{|l|c|c|c|c|}
\hline Variable & Coefficient & SE & $t$-value & $p$-value \\
\hline Intercept & .4829 & .0578 & 8.36 & $<.0001$ \\
\hline County Tax Burden & .0337 & .0077 & 4.39 & $<.0001$ \\
\hline Median Income & .0861 & .0341 & 2.52 & .0116 \\
\hline Birth Rate Lagged & .4580 & .0142 & 32.14 & $<.0001$ \\
\hline Population Density & .0052 & .0015 & 3.47 & .0005 \\
\hline Year 1997 & -.0045 & .0139 & -.33 & .7447 \\
\hline Year 2002 & -.0061 & .0139 & -.44 & .6601 \\
\hline Government Size & -.0179 & .0392 & -.457 & .6476 \\
\hline Taxation Burden & -.0343 & .0498 & -.69 & .4911 \\
\hline Union Density & -.0368 & .0122 & -3.03 & .0025 \\
\hline Minimum Wage & .0399 & .0389 & 1.02 & .3057 \\
\hline & & & & \\
\hline AIC & 1989.4 & & Observations & 3249 \\
\hline BIC & 2074.6 & & Border Areas & 174 \\
\hline & & & States & 45 \\
\hline
\end{tabular}

The hypotheses can be examined using the results in the full models for matched birth and death rates. The matched overall tax burden is hypothesized to have a negative effect on both matched firm birth and death rates. I find a negative relationship between matched taxation level and matched firm birth rates $(-.2680 ; p<.0001)$ supporting hypothesis 1 . No relationship is found between matched overall tax burden and firm death rates $(-.0343 ; p=.4911)$. Thus, no support is found for hypothesis 2 . Matched government size is hypothesized to have a negative impact on both matched firm birth and death rates. Matched government size was not a statistically significant predictor of either matched firm birth rates $(.0460 ; p=.3814)$ or death rates $(-.0179 ; p=.6476)$.

Thus, neither hypothesis 3 or 4 was supported.

Hypothesis 5 predicts a negative relationship between matched minimum wages and matched new firm birth rates. There is no support found for this hypothesis $(.0483 ; p$ 
$=.3453$ ). Hypothesis 6 predicts a positive relationship between matched union densities and matched new firm births, but this hypothesis is not supported $(-.0254 ; p=.1045)$. Hypothesis 7 predicts a negative relationship between matched minimum wages and matched firm death rates. This relationship is not found to be significant .0399; $p=$ .3057). Hypothesis 8 predicts a positive relationship between matched union densities and matched firm death rates. However, a statistically significant negative relationship is found $(-.0368 ; p=.0025)$ instead.

\section{Service verse manufacturing}

Hypothesis 9 predicts that matched overall tax burden will have a stronger negative impact on the matched birth rates of manufacturing firms than service firms. While I expect the overall relationship to be negative, it should be significantly stronger for matched manufacturing firm births than matched service births. I test this hypothesis using an interaction term. I first copy each observation, creating a dataset with 6,606 observations. I create a new variable ("matched sector birth rate") that represents either the service or manufacturing birth rate for each county. Each of the original observations now are in the dataset twice and have two different values for sector births, one representing the matched service firm birth rate and the other representing matched manufacturing firm birth rate. A dummy variable ("manufacturing") is added that equals 1 if sector birth rate variable represents the matched manufacturing birth rate and equals zero if sector birth rate represents the matched service birth rate. I construct an interaction term by multiplying the taxation burden variable by the dummy variable "manufacturing." Based on hypothesis 9, I would expect the interaction to have a 
negative coefficient. This would indicate that for manufacturing firms, the relationship between the matched overall tax burden and matched firm births is stronger (more strongly negative) than for service firms.

For years 1992 and 1997, industries are categorized by SIC codes. Industries with two digit SIC codes of 40-49 (transportation, communication, electric gas, and sanitary services), 50-51 (wholesale trade), 52-59 (retail trade), 60-67 (finance, insurance, and real estate), and 70-89 (services) are considered service firms. For year 2002, industries are labeled with NAICS codes. Firms associated with two digit NAICS codes of 42 (wholesale trade), 44-45 (retail trade), 48-49 (transportation and warehousing), 51 (information), 52 (finance and insurance), 53 (real estate and rental leasing), 54 (professional, scientific, and technical services), 55 (management of companies and enterprises), 56 (administrative and support and waste management and remediation services), 61 (education services), 62 (health care and social assistance), 71 (arts, entertainment, and recreation), 72 (accommodation and food services), and 81(other services) are considered service firms. 
Table 4.9: Interaction Model: Sector Firm Birth Rate

\begin{tabular}{|l|c|c|c|c|}
\hline Parameter & Coefficient & SE & $t$-value & $p$-value \\
\hline Intercept & .9476 & .1977 & 4.79 & $<.0001$ \\
\hline County Tax Burden & -.0125 & .0249 & -.50 & .6159 \\
\hline Median Income & -.2491 & .1041 & -2.39 & .0167 \\
\hline Death Rate Lagged & .4694 & .0475 & 9.89 & $<.0001$ \\
\hline Population Density & -.0141 & .0047 & -3.01 & .0027 \\
\hline Year 1997 & -.0374 & .0435 & -.86 & .3893 \\
\hline Year 2002 & .3887 & .0441 & 8.82 & $<.0001$ \\
\hline Government Size & .0074 & .1170 & .06 & .9457 \\
\hline Taxation Burden & -.2685 & .1701 & -1.58 & .1146 \\
\hline Union Density & -.0390 & .0368 & -1.06 & .2881 \\
\hline Minimum Wage & .1040 & .1161 & .90 & .3706 \\
\hline Manufacturing & .1040 & .1802 & .58 & .5638 \\
\hline Manufacturing*Taxation & .3571 & .1726 & 2.07 & .0386 \\
Burden & & & & \\
\hline & & & & \\
\hline AIC & 21574.57 & & & \\
\hline BIC & 21682.08 & & & \\
\hline Observations (level-1) & 5935 & & & \\
\hline
\end{tabular}

The results can be seen in Table 4.9. The coefficient on the interaction term Manufacturing*Taxation Burden was statistically significant $(3.571 ; p=.0386)$.

However, it is in the opposite direction as hypothesized. Thus, hypothesis 9 is not supported. 
Table 4.10: Results Summary

\begin{tabular}{|l|l|l|}
\hline & \multicolumn{1}{|c|}{ Hypothesized Relationship } & \multicolumn{1}{|c|}{ Results } \\
\hline H1 & $\begin{array}{l}\text { There is a negative relationship between the matched overall } \\
\text { tax burden and the matched firm birth rate. }\end{array}$ & Supported \\
\hline H2 & $\begin{array}{l}\text { There is a negative relationship between the matched overall } \\
\text { tax burden and the matched firm death rate. }\end{array}$ & Not supported \\
\hline H3 & $\begin{array}{l}\text { There is a negative relationship between the matched state } \\
\text { government size and the matched firm birth rate. }\end{array}$ & Not supported \\
\hline H4 & $\begin{array}{l}\text { There is a negative relationship between the matched state } \\
\text { government size and the matched firm death rate. }\end{array}$ & Not supported \\
\hline H5 & $\begin{array}{l}\text { There is a negative relationship between the matched } \\
\text { minimum wage and the matched firm birth rate. }\end{array}$ & Not supported \\
\hline H6 & $\begin{array}{l}\text { There is a positive relationship between the matched union } \\
\text { density and the match firm birth rate. }\end{array}$ & Not supported \\
\hline H7 & $\begin{array}{l}\text { There is a negative relationship between the matched } \\
\text { minimum wage and the matched firm death rate. }\end{array}$ & Not supported \\
\hline H8 & $\begin{array}{l}\text { There is a positive relationship between matched union } \\
\text { density and the matched firm death rate. }\end{array}$ & Not supported \\
\hline H9 & $\begin{array}{l}\text { A high matched overall tax burden will have a stronger } \\
\text { negative impact on the matched birth rate of manufacturing } \\
\text { firms than service firms. }\end{array}$ & Not supported \\
\hline
\end{tabular}

\subsection{DISCUSSION}

Although several of the hypotheses are not supported, the findings are

informative. Several explanations exist for why government size, minimum wages, and unionization may account little for regional variations in firm births and deaths.

I hypothesized that small state government size should be associated with higher firm birth rates and higher firm death rates. However, no significant relationships were found. Perhaps large state governments are better able to provide certain public goods, such as roads, police protection, court systems, and basic research, while states with smaller governments may underinvest in these public goods. If these types of services 
are beneficial to startups, this may explain why government size does not predict firm birth or death rates.

I hypothesized that high levels of unionization would be positively related to the matched firm birth rate and the matched firm death rate. However, a negative relationship is found between the matched union density and the matched firm death rate. It seems strange that this relationship is observed, since unionization if often found to exert a negative financial impact on businesses. Unionized workers typically earn more money than equivalent non-unionized employees (Duncan \& Stafford, 1980; Kwoka Jr, 1983; Stewart, 1990) and having a unionized workforce has been associated with lower firm profitability (Hirsch, 1991; Menezes-Filho, 1997; Voos \& Mishel, 1986). However, for smaller firms in areas that are highly unionized, the wage rates for their non-union workers may be lower making their labor costs lower than areas with higher unionization rates. Although no significant relationship was found between matched minimum wages and either matched birth or death rates, this finding may be due to the fact that differences in minimum wages are relatively modest between states. Furthermore, high minimum wages are likely to only deter certain types of startups- those that rely on relatively cheap, unskilled labor. While high minimum wages may deter an entrepreneur from starting an ice cream shop, they will be unlikely to deter an entrepreneur from starting up a biotechnology firm.

A failure to find support for some of the hypotheses may be due to prospective entrepreneurs not "shopping around" much for an area which provides the optimal climate in which to do business. Perhaps, entrepreneurs just start their business in the 
county and state in which they reside. Even if it is advantageous for an entrepreneur to start their business in a nearby state, many entrepreneurs may not be aware of any advantage in doing so. Or alternatively, it may be that entrepreneurs do have a good understanding of such differences, but choose their location based upon other factors. As mentioned before, if there is demand for hot pizza in Salisbury Massachusetts, but not in Portsmouth New Hampshire, it does not make sense for an entrepreneur to start a pizzeria in New Hampshire regardless of other advantages. Entrepreneurs have to consider a number of factors when determining the location of a business such as market size (Davidsson, Lindmark, \& Olofsson, 1994) and access to human capital and knowledge (Audretsch, Lehmann, \& Warning, 2005; Zucker, Darby, \& Brewer, 1998). Although the matching technique should eliminate many confounding variables, it certainly cannot eliminate all of them. Finally, there is a cost to starting a business in a location other than the one in which the entrepreneur resides, even a nearby one. Crossing the state border to start a business may entail commuting or incurring relocation costs.

\subsection{LIMITATIONS AND FUTURE RESEARCH}

There are several limitations to this study. The matching technique used in this study has the advantage of limiting- although not eliminating the threat of confounding variables. Counties that sit on state borders are likely to be similar to those on the other side of the state border in culture, human capital, natural resources, and access to customers and suppliers. Thus, any relationship between the differences in taxes and regulations and differences between firm births and deaths is more likely to be a causal one. However, matching counties on different sides of state borders is not a perfect 
control, since taxation and regulatory differences may not be the only characteristic that differs on different sides of state borders. This technique has minimized, but not eliminated threats to internal validity.

Another limitation of this study is the difficulty controlling for county and citylevel differences in taxation and regulation. These jurisdictions are often empowered to regulate business, and often do. For example, New York City has recently banned restaurants from serving food with trans-fats, while restaurants in cities in neighboring New Jersey do not face these regulations as of yet (Wilner \& Olshan, 2008). Thus, city level regulations may have an impact on differences in firm births and deaths in this border area, confounding any relationship found between counties on differing sides of the state border. Also, I do not examine the differences in how governments actually spend their money. What governments spend their money on may be more important than how much they actually spend. Government spending focused on income redistribution may deter the birth of new firms, while government spending on education has been observed to have the opposite effect (Stansel, Gohmann, \& Hobbs, 2008).

This study is also limited by the fact they there is no differentiating of births and deaths of productive firms and those that are unproductive or destructive. Baumol (1990) argues that the institutional environment has a profound impact on the type of entrepreneurship displayed in an economy. Just because there are births of new firms, this does not mean that such firms are productive and ultimately contribute to economic growth. In fact, many entrepreneurial ventures including certain lobbying firms, likely do not have a positive impact on economic growth. Likewise, interpretation of death 
rates may be problematic as well. Although the failure of a firm is painful for those owning the business, failure is often necessary and a natural part of economic development. Schumpeter (1942) argues that new entrants introduce "new combinations" or innovations that often lead to the decline and possibly death of existing firms. Thus, it is difficult to discern the overall economic impact of a high level of firm deaths.

Examining how taxes and regulations influence different industries is a fruitful area for future research. In this essay, I do not evaluate births and deaths by industry, other than a broad breakdown between service and manufacturing firms. It may be that taxes, government sizes, unionization, and minimum wages influence firm births and deaths, but only within certain industries. The establishment births and death data used in this study contains the number of firm births and deaths in each county by five digit industry codes. Thus, the potential to examine very specific industries exist with the data. However, the difficulty with doing this is that many smaller counties would have to be excluded from such an analysis, since they may contain very few births and deaths in certain industries (or perhaps none at all). However, such an analysis could be done with counties with larger populations, such as those in metropolitan areas.

\subsection{CONCLUSION}

In this essay, I hypothesized that small government size, low taxation levels, high levels of unionization and low minimum wages will be associated with relatively high new firm birth and death rates. I found support for a negative relationship between overall tax burden and the birth rate of new firms. However, unionization, minimum 
wages and government size did not influence the birth and death rates of firms in the manner hypothesized. Likewise, I did not find support for the hypothesis that high taxation levels would deter the birth of manufacturing firms more than service firms. 


\section{CHAPTER 5: SUMMARY}

This dissertation consists of three essays that examine the influence of formal institutions on the behavior of entrepreneurs. Institutions set the "rules of the game" in an economy, determining incentives, reducing uncertainty, and influencing transaction costs (North, 1987). The rules of the gamine influence the activities of all "players" in an economy, and entrepreneurs are no exception. Institutions influence the level (McMullen, Bagby, \& Palich, 2008; Ovaska \& Sobel, 2005) and type of entrepreneurship in an economy (Baumol, 1990; Sobel, 2008). In this dissertation, I build on this research by examining how institutions influence the behavior of entrepreneurs in three different contexts. I will briefly summarize the findings from each of these separate essays.

The first essay "The Influence of Institutions on the Likelihood of SelfEmployment: A Multilevel Analysis" I examined the relationship between institutions at the country-level and how those institutions are related to the likelihood that individuals in that country will be self-employed. Country-level institution measures used in the analysis include taxation levels, the strength of property rights, soundness of money, trade freedom, and the level of business regulation. Two measures of country-level formal institutions are used: The Economic Freedom of the World index (Gwartney, Lawson, Sobel, \& Leeson, 2007) and the Index of Economic Freedom (Heritage Foundation, 2005). These country-level measures are paired with individual-level data 
on self-employment from the Global Entrepreneurship Monitor (Reynolds et al., 2005). The GEM survey is a cross-country data collection project that surveys individuals about their engagement (or lack of engagement) in entrepreneurship (Reynolds, Bygrave, Autio, Cox, \& Hay, 2004). I use data from 2001-2006, and my sample includes data from 472,363 individuals and 55 unique countries. The country-level measures of institutions as well as individual-level control variables are used to predict whether individuals are self-employed.

With both the Economic Freedom of the World and the Index of Economic Freedom measures, I find that sound money in a country is positively associated with the likelihood of an individual being self-employed. Likewise, a positive relationship was found between property rights and trade freedom and the likelihood that an individual would be self-employed with the Economic Freedom of the World (EFW) measure. However, this was not found with measures from the Index of Economic Freedom. Measures of taxation/government size and the level of business regulation did not predict the likelihood of being self-employed in the hypothesized direction. While four interactions were hypothesized, no significant relationships were found.

In the second essay "Labor Market Institutions and New Firm Employment Growth," I examined how state-level labor market factors such as minimum wages, union density, and unemployment insurance premiums influence employment growth in new firms. Given that new firms are often are resource-constrained and have less access to capital than more established firms (Carpenter \& Petersen, 2002; Holtz-Eakin, Joulfaian, \& Rosen, 1994), new firms must conserve capital during their formative years. Thus, I 
hypothesized that high minimum wages and unemployment insurance programs that were costly and penalized firms for firing workers would keep firms from growing their level of employment. Given that labor unions are often going to make labor more costly for larger, incumbent firms, I also hypothesized that high union densities would be associated with higher employment growth in new firms.

I obtained firm-level data from Kauffman Firm Survey (DesRoches, Robb, \& Mulcahy, 2009), which contains data on several thousand new firms across five waves from years 2004-2008. The sample includes 2,662 observations in the baseline wave, 2,107 observations in the first follow up wave, 1,802 observations in the second follow up wave, 1,553 observations in the third follow up wave, and 1,391 in the fourth follow up wave. These data were matched with state-level data minimum wage, unemployment tax, and unionization data.

None of these variables was found to have the hypothesized effect. Minimum wages and the unemployment insurance structure did not predict the level of employment in new firms. While state union density did have a marginally significant effect, the relationship is negative, while a positive relationship was hypothesized.

In the third essay "The Impact of Taxes and Regulations on New Firm Births and Deaths in State Border Counties" I examined how state-level measures of government size, tax burdens, unionization levels, and minimum wages influence the birth and death rates of new firms in counties located on state borders. Data on firm births and deaths by industry were obtained from a custom tabulation from the U.S. Census Bureau's Company Division. These tabulations contain data on establishment births and deaths for 
each county in the United States from 1989-2005 (Plummer \& Headd, 2008). These data were merged with measures of government size, tax burdens, union densities, and minimum wages from the Economic Freedom of North America index (Karabegovic, McMahon, \& Mitchell, 2005). In the analysis, I examined counties on state borders, matching and these counties with counties on the other side of the state border. I matched counties with counties that are contiguous with one another and that lie across a state border. I used data from the years 1992, 1997, and 2002. The variables were not used in their raw form; they were matched with those of bordering counties in a similar manner as Holcombe and Lacombe (Holcombe \& Lacombe, 2004a, b).

I found support for a negative relationship between overall tax burden and the birth rate of new firms. However, unionization, minimum wages and government size did not influence the birth and death rates of firms in the manner hypothesized. I did not find support for the hypothesis that high taxation levels would deter the birth of manufacturing firms more than service firms.

\section{Future Research Possibilities}

There are several avenues of future research regarding the influence of formal institutions on entrepreneurship. In Chapter 3 (Essay 2) I examined how labor market institutions influence employment growth in new firms. However, little research has examined the impact that institutions have on firm growth; instead it has focused on how institutions influence the prevalence of self-employment as well as the births and deaths of firms (Bjornskov \& Foss, 2008; McMullen et al., 2008). Future research should further examine the link between institutions and firm growth. For example, business 
regulations may limit firm growth by making operating a business more expensive. Alternatively, they may allow existing firms to grow more rapidly if they serve as an effective barrier to entry.

The relationship between institutions and firm growth becomes even more interesting when we consider that entrepreneurs tend to be overconfident (Busenitz \& Barney, 1997). This may lead to poor decision making on the part of entrepreneurs (Hayward, Shepherd \& Griffin, 2006). Since entrepreneurs are overconfident, they may not accurately weigh the negative effect that certain institutional environments may have on their business. For example, an overconfident entrepreneur may start a business even when business regulation is substantial, because he or she may vastly underestimate the time and resources required to overcome regulatory hurdles. Likewise, an overconfident entrepreneur may overestimate the amount of tax deductions he or she will be able to claim, thus underestimating the tax burden they will endure. This may be addressed by testing interaction effects between cognitive variables such as overconfidence, and institutional measures, such as the level of business regulation, taxation and property rights. However, this would require a large individual-level survey across multiple countries that include measures of cognitive biases (such as overconfidence) which are not contained in surveys such as the Global Entrepreneurship Monitor survey. Another approach may be to perform a conjoint experiment in which entrepreneurs are asked if they would start a given business given certain institutional variables. These may include tax rates, regulatory burdens, risk of property expropriation, etc. Choi and Shepherd (2004) used a conjoint analysis in order to show how customer demand, the development 
of enabling technologies, capability of the management team, and stakeholder support influence an entrepreneur's decision to begin opportunity exploitation. A similar experiment could be conducted to examine how different institutional environments influence the exploitation decision of entrepreneurs. Interactions could be tested between institutional and individual-level variables. While such an approach has limitations, it would not require collecting individual-level survey data from multiple countries.

One limitation of much of the research regarding the relationship between institutions and entrepreneurship has implicitly assumed that entrepreneurship is a desirable activity. While researchers are often careful to make positive statements instead of normative ones, the large amount of research that uses entrepreneurship or the level of entrepreneurship as the dependent variable shows the attention that has been given to entrepreneurship. This attention suggests that entrepreneurship is often viewed as something that is socially desirable. Entrepreneurship has been linked to economic outcomes like job creation and economic growth (Carree, van Stel, Hafer, 2011, Thurik, \& Wennekers, 2002; Fölster, 2000). However, Baumol (1990) recognized that not all entrepreneurship is socially productive; some entrepreneurship is unproductive and even destructive. One problem is that it is difficult to determine what entrepreneurship is productive, unproductive, and destructive. Sobel (2008) attempts to do this by using measures such as firm births and patenting activity to represent productive entrepreneurship. He uses the number of lobbying firms and the quality of the state's liability system as measures of unproductive entrepreneurship. However, using firm births (and even patenting activity) as a measure of productive entrepreneurship may be 
problematic, since they are crude proxies for productive entrepreneurship. Examining how institutions influence unproductive and destructive entrepreneurship may be useful as well. Besides the number of lobbying firms used by Sobel (2008), another possible measure of unproductive and destructive entrepreneurship may be the percentage of individuals engaging in drug dealing or property crimes. Developing better ways to examine the influence of institutions on both productive and unproductive entrepreneurship remains a fruitful area for research.

In Chapter 4 (Essay 3) I matched counties that are contiguous with one another and that lie across a state border. This method is a good way to control for factors, even those that are unobservable and immeasurable, that may vary based on location. Any observed relationship is less likely to be due confounding factors. Due to this advantage, matching techniques have been used in a number of studies (Bronars \& Lott, 1998; Card, 1992; Dube, Lester, \& Reich, 2007; Holcombe \& Lacombe, 2004a, b; Holmes, 1998). This kind of matching technique can be applied to examine the impact of a number of state-level institutions and policies. One specific example would be examining how taxes and regulations influence the births and deaths of firms in different industries. The establishment births and death data used in this study contains the number of firm births and deaths in each county by five digit industry codes making such an analysis possible. Taxation, property rights, and business regulation are likely to have different effects on the birth and death of firms depending on the industry in which they operate in. 


\section{REFERENCES}

Aaronson, D. 2001. Price pass-through and the minimum wage. Review of Economics and Statistics, 83: 158-169.

Acemoglu, D. 1995. Reward structures and the allocation of talent. European Economic Review, 39(1): 17-33.

Acs, Z. J., \& Audretsch, D. B. 1989. Small-firm entry in US manufacturing. Economica, 56(22): 255-265.

Addison, J. T., \& Barnett, A. H. 1982. The impact of unions on productivity British Journal of Industrial Relations, 20: 145-162.

Aidis, R., Estrin, S., \& Mickiewicz, T. 2009. Entrepreneurial entry: Which institutions matter?: 46: Institute for the Study of Labor.

Anderson, K. 2002. Peculiarities of retaliation in WTO dispute settlement. World Trade Review 1(2): 123-134.

Anderson, P. M., \& Meyer, B. D. 1993. Unemployment insurance in the United States: Layoff incentives and cross subsidies. Journal of Labor Economics, 11(1): S70S95.

Anderson, W., Wallace, M., \& Warner, J. 1986. Government spending and taxation: What causes what? Southern Economic Journal, 52: 630-639.

Andersson, S., \& Evangelista, F. 2006. The entrepreneur in the Born Global firm in Australia and Sweden. Journal of Small Business and Enterprise Development 13: 642-659.

Antonova, S., \& Tudoreanu, M. 2009. The effects of a raised minimum wage on employment: Differences across states and social groups. Issues in Political Economy 19: 68-89.

Antunes, A., \& Cavalcanti, T. 2007. Start up costs, limited enforcement, and the hidden economy. European Economic Review, 51: 203-224. 
Arenius, P., \& Minniti, M. 2005. Perceptual variables and nascent entrepreneurship. Small Business Economics, 24: 233-247.

Armington, C., \& Acs, Z. J. 2002. The determinants of regional variation in new firm formation. Regional Studies, 36(1): 33-45.

Arrowsmith, J., Gilman, M. W., Edwards, P., \& Ram, M. 2003. The impact of the national minimum wage in small firms. British Journal of Industrial Relations, 41: 435-456.

Audretsch, D., Lehmann, E., \& Warning, S. 2005. University spillovers and new firm location. Research policy, 34: 1113-1122.

Auerbach, A. J., \& Feenberg, D. 2000. The significance of federal taxes as automatic stabilizers. The Journal of Economic Perspectives, 14(3): 37-56.

Ayal, E. B., \& Karras, G. 1998. Components of economic freedom and growth: An empirical study. The Journal of Developing Areas, 32: 327-338.

Baker, M., Benjamin, D., \& Stanger, S. 1999. The highs and lows of the minimum wage effect: A time-series cross-section study of the Canadian law. Journal of Labor Economics, 17: 318-350.

Baland, J.-M., \& Francois, P. 2000. Rent-seeking and resource booms. Journal of Development Economics, 61(2): 527-542.

Baldwin, J. R., \& Gellatly, G. 1998. Are there high-tech industries or only high-tech firms? Evidence from new technology-based firms. Working paper No. 120. Micro-Economic Analysis Division, Ottawa, Canada.

Barney, J. B. 1997. Gaining and sustaining competitive advantage. Reading, MA: Addison-Wesley Publishing Company.

Barro, R. J. 1996. Democracy and growth. Journal of Economic Growth, 1(1): 1-27.

Barro, R. J., \& Xavier, S. 1992. Convergence. Journal of Political Economy, 100: 223251.

Bartik, T. 1985. Business location decisions in the United States: Estimates of the effects of unionization, taxes, and other characteristics of states. Journal of Business $\boldsymbol{\&}$ Economic Statistics, 3(1): 14-22.

Barzel, Y. 1997. Economic analysis of property rights: Cambridge University Press 
Bates, T. 1990. Entrepreneur human capital inputs and small business longevity. The Review of Economics and Statistics, 72: 551-559.

Bates, T. 1995. Self-employment entry across industry groups. Journal of Business Venturing, 10(2): 143-156.

Baumol, W. 1990. Entrepreneurship: Productive, unproductive, and destructive Journal of Political Economy, 98: 893-921.

Baumol, W., \& Caves, R. 1993. Entrepreneurship, management, and the structure of payoffs: MIT press Cambridge, MA.

Becker, G. S. 1975. Human capital (2nd ed.). Columbia University Press: New York.

Bélanger, J., \& Murray, G. 1994. Unions and economic restructuring. Industrial Relations, 49: 639-656.

Belot, M., \& Van Ours, J. C. 2001. Unemployment and labor market institutions: An empirical analysis. Journal of Japanese and International Economics 15: 403418.

Bergsten, C. F. 2001. Fifty years of trade policy: The policy lessons. World Economy 24(1): 1-13.

Besley, T. 1995. Property rights and investment incentives: Theory and evidence from Ghana. Journal of Political Economy: 903-937.

Birch, D. 1987. Job creation in America: How our smallest companies put the most people to work: The Free Press.

Birley, S. 1986. The role of new firms: Births, deaths and job generation. Strategic Management Journal, 7: 361-376.

Bjornskov, C., \& Foss, N. J. 2008. Economic freedom and entrepreneurial activity: Some cross-country evidence. Public Choice, 134: 307-328.

Blanchard, O., \& Tirole, J. 2008. The joint design of unemployment insurance and employment protection: a first pass. Journal of the European Economic Association, 6(1): 45-77.

Blanchard, O. J., \& Summers, L. H. 1986. Hysteresis and the European unemployment problem. NBER macroeconomics annual: 15-78. 
Blanchflower, D., Oswald, A., \& Stutzer, A. 2001. Latent entrepreneurship across nations. European Economic Review, 45: 680-691.

Blanchflower, D. G. 2000. Self-employment in OECD countries. Labour Economics, 7: 471-505.

Bliese, P. 2009. Multilevel modeling in R (2.3): A brief introduction to R, the multilevel package and the nlme package.

Bliese, P., \& Ployhart, R. 2002. Growth modeling using random coefficient models: Model building, testing, and illustrations. Organizational Research Methods, 5: 362.

Bowen, D., \& Jones, G. 1986. Transaction cost analysis of service organization-customer exchange. Academy of Management Review, 11: 428-441.

Bradley, B. 2009. ESPN College Basketball Encyclopedia: The Complete History of the Men's Game, New York: Random House

Bratsberg, B., \& Ragan Jr, J. 2002. Changes in the union wage premium by industry. Industrial and Labor Relations Review, 56: 65-83.

Brockner, J., Higgins, E. T., \& Low, M. B. 2004. Regulatory focus theory and the entrepreneurial process. Journal of Business Venturing, 19: 203-220.

Bronars, S., \& Lott, J. 1998. Criminal deterrence, geographic spillovers, and the right to carry concealed handguns. The American Economic Review, 88: 475-479.

Brown, C., Gilroy, C., \& Kohen, A. 1982. The effect of the minimum wage on employment and unemployment. Journal of Economic Literature, 20: 487-528.

Brown, C., \& Medoff, J. 1989. The employer size-wage effect. The Journal of Political Economy, 97: 1027-1059.

Brown, D., \& Crossman, A. 2000. Employer strategies in the face of a national minimum wage: an analysis of the hotel sector. Industrial Relations Journal, 31: 206-219.

Brown, D. K., Deardorff, A. V., \& Stern, R. M. 1992. A North American free trade agreement: Analytical issues and a computational assessment. The World Economy 15(1): 11-30.

Bruce, D., \& Gurley-Calvez, T. 2008. Federal tax policy and small business. In D. Furchtgott-Roth (Ed), Overcoming barriers to entrepreneurship in the United States. Lanham, MD: Rowman \& Littlefield. 
Bruce, D., \& Mohsin, M. 2006. Tax policy and entrepreneurship: New time series evidence. Small Business Economics, 26: 409-425.

Bruce, D., \& Schuetze, H. J. 2004. Tax policy and entrepreneurship. Swedish Economic Policy Review, 2(11): 233-265.

Bruderl, J., \& Schussler, R. 1990. Organizational mortality: The liabilities of newness and adolescence. Administrative Science Quarterly, 35(3).

Brunetti, A., Kisunko, G., \& Weder, B. 1997. Institutional obstacles to doing business: World Bank

Bruno, M., \& Easterly, W. 1998. Inflation crises and long-run growth. Journal of Monetary Economics, 41(1): 3-26.

Bureau of Labor Statistics. 2010. Union members in 2009. Washington, D.C. http://www.bls.gov/news.release/pdf/union2.pdf

Busenitz, L. \& Barney, J. 1997. Differences between entrepreneurs and managers in large organizations: Biases and heuristics in strategic decision-making. Journal of Business Venturing, 12(1): 9-30.

Cahuc, P., \& Postel-Vinay, F. 2002. Temporary jobs, employment protection and labor market performance. Labour Economics, 9: 63-91.

Campbell, A. J. 1996. The effects of internal firm barriers on the export behavior of small firms in a free trade environment. Journal of Small Business Management, 34(3): 50-58.

Campbell, N. D., \& Rogers, T. M. 2007. Economic freedom and net business formation. Cato Journal, 27(1): 23-36.

Caputo, R. K., \& Dolinsky, A. 1998. Women's choice to pursue self- employment: The role of financial and human capital of household members. Journal of Small Business Management, 36(3): 8-17.

Card, D. 1992. Do minimum wages reduce employment? A case study of California, 1987-89. Industrial and Labor Relations Review, 46: 38-54.

Card, D., \& Krueger, A. 1994. Minimum wages and employment: A case study of the fast food industry. American Economic Review, 84: 772-793.

Card, D., \& Krueger, A. B. 1995. Myth and measurement: The new economics of the minimum wage: Princeton University Press. 
Cardon, M. S., \& Stevens, C. E. 2004. Managing human resources in small organizations: what do we know? Human Resource Management Review 14: 295-323.

Carman, J. M., \& Langeard, E. 1980. Growth strategies for service firms. Strategic Management Journal, 1: 7-22.

Carpenter, R. E., \& Petersen, B. C. 2002. Is the growth of small firms constrained by internal finance? Journal of Political Economy, 84: 298-309.

Carree, M., van Stel, A., Thurik, R., \& Wennekers, S. 2002. Economic development and business ownership: An analysis using data of 23 OECD countries in the period 1976-1996. Small Business Economics, 19: 271-290.

Carroll, R., Holtz-Eakin, D., Rider, M., \& Rosen, H. 2001. Personal income taxes and the growth of small firms. Tax Policy and the Economy: 121-147.

Carter, N. M., \& Brush, C. 2004. Gender. In W. B. Gartner, K. G. Shaver, N. M. Carter, \& P. Reynolds (Eds.), Handbook of entrepreneurial dynamics. Thousand Oaks, CA: Sage.

Chen, P., \& Popovich, P. 2002. Correlation: Parametric and nonparametric measures. Thousand Oaks, CA: Sage.

Choi, Y., \& Shepherd, D. 2004. Entrepreneurs' decisions to exploit opportunities. Journal of Management. 30: 377-395.

Christie, V. 2007. Union wage effects and the probability of union membership. Economic Record, 68(1): 43-56.

Claessens, S., \& Laeven, L. 2003. Financial development, property rights, and growth. Journal of Finance: 2401-2436.

Clark, K. B. 1984. Unionization and firm performance: The impact on profits, growth, and productivity. The American Economic Review, 74: 893-919.

Colvin, R. A. 2000. Improving state policies prohibiting public employment discrimination based on sexual orientation. Review of Personnel Administration 20(2): 5 .

Cooper, A., Gimeno-Gascón, F., \& Woo, C. 1997. Initial human and financial capital as predictors of new venture performance. The Journal of Private Equity, 1(2): 1330 . 
Corey, Joab. 2009. Development in US states, economic freedom, and the "resource curse". Studies in mining policy. Vancover, BC: Fraser Institute.

Cornes, R., \& Sandler, T. 1996. The theory of externalities, public goods, and club goods. Cambridge: Cambridge University Press.

Cox, D., \& Harris, R. 1985. Trade liberalization and industrial organization: Some estimates for Canada. The Journal of Political Economy, 93: 115.

Crowe, E., \& Higgins, E. T. 1997. Regulatory focus and strategic inclinations: Promotion and prevention in decision-making. Journal of Personality and Social Psychology, 69(2): 117-132.

Dal Bo, E. 2006. Regulatory capture: a review. Oxford Review of Economic Policy, 22(2): 203.

Darby, M. R., Liu, Q., \& Zucker, L. G. 1999. Stakes and stars: The effect of intellectual human capital on the level and variability of high-tech firms' market values: National Bureau of Economic Research.

Dardis, R., Spivak, S., \& Shih, C. 1985. Price and quality differences for imported and domestic men's dress shirts. Family and Consumer Sciences Research Journal, 13: 391 .

Davidsson, P. 2004. Researching Entrepreneurship, New York: Springer.

Davidsson, P., \& Honig, B. 2003. The role of social and human capital among nascent entrepreneurs. . Journal of Business Venturing, 18: 301-331.

Davidsson, P., Lindmark, L., \& Olofsson, C. 1994. New firm formation and regional development in Sweden. Regional Studies, 28: 395-410.

Davidsson, P., Lindmark, L., \& Olofsson, C. 1998. The extent of overestimation of small firm job creation-an empirical examination of the regression bias. Small Business Economics, 11: 87-100.

Davis, J. C., \& Huston, J. H. 1995. Right-to-work laws and union density: New evidence from micro data. Journal of Labor Research, 16: 223-229.

Dawson, J. W. 1998. Institutions, investment, and growth: New cross-country and panel data evidence. Economic Inquiry, 36: 603-619.

Dawson, J. W. 2003. Causality in the freedom-growth relationship. European Journal of Political Economy, 19: 479-495. 
De Haan, J., \& Sturm, J. 2000. On the relationship between economic freedom and economic growth. European Journal of Political Economy, 16: 215-241.

De Soto, H. 1989. The other path. New York: Harper \& Row.

Demsetz, H. 1967. Toward a theory of property rights. The American Economic Review, 57: 347-359.

DesRoches, D., Robb, A., \& Mulcahy, T. M. 2009. Kauffman firm survey (KFS) baseline/first/second follow ups: Study metadata documentation

Dickens, R., Machin, S., \& Manning, A. 1999. The effects of minimum wages on employment: Theory and evidence from Britain. Journal of Labor Economics, 17: 1-22.

Dippolito, A., Braslow, B., Lombardo, G., Hoddinott, K., Nace, G., \& Stawicki, S. 2008. How David beat Goliath: History of physicians fighting frivolous lawsuits. OPUS, 12(1): 1-8.

Djankov, S., La Porta, R., Lopez-De-Silanes, F., \& Shleifer, A. 2002. The regulation of entry. The Quarterly Journal of Economics 117(1): 1-37.

Dollar, D. 1992. Outward-oriented developing economies really do grow more rapidly: Evidence from 95 LDCs, 1976-1985. Economic development and cultural change, 40: 523-544.

Domar, E., \& Musgrave, R. 1944. Effects of proportional taxes on risk-taking. Quarterly Journal of Economics, 58: 388-422.

Dube, A., Lester, T., \& Reich, M. 2007. Minimum wage effects across state borders: Estimates using contiguous counties. Working paper series Vol. 157: Institute for Research on Labor and Employment.

Duncan, G., \& Stafford, F. 1980. Do union members receive compensating wage differentials? The American Economic Review, 70: 355-371.

Dunn, T., \& Holtz-Eakin, D. 2000. Financial capital, human capital, and the transition to self-employment: Evidence from intergenerational links. Journal of Labor Economics, 18: 282-305.

Easton, S., \& Walker, M. 1997. Income, growth, and economic freedom. The American Economic Review, 87: 328-332. 
Eckel, P. D., \& King, J. E. 2004. An overview of high education in the United States: Diversity, access and the role of the marketplace American Council on Education

Ellwood, D., \& Fine, G. 1987. The impact of right-to-work laws on union organizing. The Journal of Political Economy, 95: 250-273.

Emerson, M. 1988. Regulation or deregulation of the labour market: Policy regimes for the recruitment and dismissal of employees in the industrialised countries. European Economic Review, 32: 775-817.

Enders, C., \& Tofighi, D. 2007. Centering predictor variables in cross-sectional multilevel models: A new look at an old issue. Psychological Methods, 12(2): 121.

Erramilli, M., \& Rao, C. 1993. Service firms' international entry-mode choice: A modified transaction-cost analysis approach. The Journal of Marketing, 57(3): 19-38.

Esping-Andersen, G., \& Korpi, W. 1987. From poor relief to institutional welfare states: The development of Scandinavian social policy. In R. Erikson, E. J. Hansen, S. Ringen, \& H. Uusitalo (Eds.), The Scandinavian model: Welfare states and welfare research, 39-74. New York: ME Sharpe Inc.

Evans, D. S., \& Leighton, L. S. 1989. Some empirical aspects of entrepreneurship. The American Economic Review, 79: 519-535.

Fairlie, R. W. 1999. The absence of the African-American owned business: An analysis of the dynamics of self-employment. Journal of Labor Economics, 17: 80-108.

Fairlie, R. W., \& Robb, A. M. 2009. Entrepreneurship, self-employment and business data: An introduction to several large, nationally-representative datasets. Discussion paper No. 4052, Institute for the Study of Labor.

Fama, E. F. 1981. Stock returns, real activity, inflation, and money. The American Economic Review, 71: 545-565.

Farber, H. S. 1984. Right-to-work laws and the extent of unionization. Journal of Labor Economics, 2: 319-352.

Fariñas, J., \& Moreno, L. 2000. Firms' growth, size and age: A nonparametric approach. Review of Industrial Organization, 17: 249-265.

Farr, W., Lord, R., \& Wolfenbarger, J. 1998. Economic freedom, political freedom, and economic well-being: a causality analysis. Cato Journal, 18: 247-262. 
Fölster, S. 2000. Do entrepreneurs create jobs? Small Business Economics, 14: 137-148.

Fölster, S. 2002. Do lower taxes stimulate self-employment? Small Business Economics 19(2): 135-145.

Förster, J., Higgins, E. T., \& Idson, L. C. 1998. Approach and avoidance strength during goal attainment: Regulatory focus and the "goal looms larger" effect. Journal of Personality and Social Psychology 75: 1115-1131.

Foss, K., \& Foss, N. 2002. Economic organization and the trade-offs between productive and destructive entrepreneurship. In N. Foss \& P. Klein (Eds.), Entrepreneurship and the firm: Austrian perspectives on economic organization: 102-127. Northamption, MA: Edward Elgar.

Freeman, J., Carroll, G. R., \& Hannan, M. T. 1983. The liability of newness: Age dependence in organizational death rates. American Sociological Review, 48: 692-710.

Freeman, R. B. 1998. War of the models: Which labour market institutions for the $21 \mathrm{st}$ century? Labour Economics, 5: 1-24.

Freeman, R. B. 2007. Labor market institutions around the world. Working paper No. W13242, National Burea of Economic Research.

Freeman, R. B., \& Medoff, J. L. 1984. What do unions do? New York: Basic Books.

Freeman, R. B., \& Nickell, S. 1988. Labour market institutions and economic performance. Economic Policy 3(6): 64-80.

Friedman, E., Johnson, S., Kaufmann, D., \& Zoido-Lobation, P. 2000. Dodging the grabbing hand: The determinants of unofficial activity in 69 countries. Journal of Public Economics, 76(3).

Friedman, M. 1977. Nobel lecture: Inflation and unemployment. The Journal of Political Economy, 85: 451-472.

Galarneau, D. 1996. Unionized workers. Perspectives on Labour and Income, 8(1): 4352.

Gallup, J., Sachs, J., \& Mellinger, A. 1999. Geography and economic development. International Regional Science Review, 22: 179.

Gallup Europe. 2009. Enterprise and industry: Small and medium-sized enterprises (SMEs). 
http://ec.europa.eu/enterprise/policies/sme/facts-figuresanalysis/eurobarometer/index_en.htm

Gartner, W. B. 1988. "Who is the entrepreneur?" Is the wrong question. American Journal of Small Business, 12: 11-32.

Gawande, K. L., \& Hansen, W. 2003. Retaliation, bargaining, and the pursuit of "free and fair" trade. International Organization, 53(1): 117-159.

Gentry, W., \& Hubbard, R. G. 2005. "Success taxes," entrepreneurial entry, and innovation. Innovation Policy and the Economy, 5(1): 87-108

Gentry, W. M., \& Hubbard, R. G. 2000. Tax policy and entry into ntrepreneurship. American Economic Review, 90: 283-287.

Gibson, P., Wainio, J., Whitley, D., \& Bohman, M. 2001. Profiles of tariffs in global agricultural markets. Agricultural economic report No. 796. Economic research service, U.S. Department of Agriculture.

Gimeno, J., Folta, T. B., Cooper, A. C., \& Woo, C. Y. 1997. Survival of the fittest? Entrepreneurial human capital and the persistence of underperforming firms. Administrative Science Quarterly 42: 750-783.

Goel, R., \& Nelson, M. 1998. Corruption and government size: A disaggregated analysis. Public Choice, 97: 107-120.

Gohmann, S., Hobbs, B., \& McCrickard, M. 2008. Economic freedom and service industry growth in the United States. Entrepreneurship Theory and Practice, 32: 855-874.

Gohmann, S. F. (in press). Institutions, latent entrepreneurship, and self-employment: An international comparison. Entrepreneurship Theory and Practice.

Grant, R. 2002. The resource-based theory of competitive advantage. In D. Faulkner (Ed.), Strategy: Critical perspectives on business and management. Routledge: New York.

Gregg, P. 2000. The use of wage floors as policy tools. OECD Economic Studies, 31(2): 133-146.

Grossman, J. 1978. Fair Labor Standards Act of 1938: Maximum struggle for a minimum wage. Monthly Labor Review, 101(6): 22-30 
Guesnier, B. 1994. Regional variations in new firm formation in France. Regional Studies, 28: 347-358.

Gwartney, J., Holcombe, R., \& Lawson, R. 2004. Economic Freedom, Institutional Quality, and Cross-Country Differences in Income and Growth. The Cato Journal, 24: 205-234.

Gwartney, J., \& Lawson, R. 2003. The concept and measurement of economic freedom. European Journal of Political Economy, 19: 405-430.

Gwartney, J., Lawson, R., \& Holcombe, R. 1999. Economic freedom and the environment for economic growth. Journal of Institutional and Theoretical Economics, 155(4): 643

Gwartney, J., Lawson, R., Sobel, R. S., \& Leeson, P. T. 2007. Economic freedom of the world: 2007 annual report. Fraser Institute, Vancouver BC.

Hafer, R. 2011. Entrepreneurship and state economic growth. Working paper.

Hall, B. H. 1987. The relationship between firm size and firm growth in the US manufacturing sector. The Journal of Industrial Economics, 35: 583-606.

Hamilton, B. 2000. Does entrepreneurship pay? An empirical analysis of the returns to self-employment. Journal of Political Economy, 108: 604-631.

Hamilton, W. L., Biener, L., \& Brennan, R. T. 2008. Do local tobacco regulations influence perceived smoking norms? Evidence from adult and youth surveys in Massachusetts. Health Education Research 23: 709.

Hannan, M., \& Carroll, G. 1992. Dynamics of organizational populations: Density, legitimation, and competition: Oxford University Press, USA.

Hannan, M., \& Freeman, J. 1993. Organizational ecology. Cambridge, MA: Harvard University Press.

Hardy, D. 2006. Regulatory capture in banking. Working paper No. 06/34, International Monetary Fund.

Hayward, M., Shepherd, D., \& Griffin, D. A hubris theory of entrepreneurship. Management Science, 52(2): 160-172.

Heckelman, J. 2000. Economic freedom and economic growth: a short-run causal investigation. Journal of Applied Economics, 3(1): 71-91. 
Heller, D., \& Rogers, K. 2006. Shifting the burden: Public and private financing of higher education in the United States and implications for Europe. Tertiary Education and Management, 12(2): 91-117.

Henrekson, M. 2005. Entrepreneurship: A weak link in the welfare state? Industrial and Corporate Change, 14: 437-467.

Henrekson, M. 2007. Entrepreneurship and institutions. Comparative Labor Law \& Policy Journal, 28: 717-742.

Heritage Foundation. 2005. Index of economic freedom. Washington, DC.

Hirsch, B. 1991. Union coverage and profitability among U.S. firms. The Review of Economics and Statistics, 73: 69-77.

Holcomb, T., Combs, J., Sirmon, D., \& Sexton, J. 2010. Modeling levels and time in entrepreneurship research: An illustration with growth strategies and post-IPO performance. Organizational Research Methods, 13: 348-389.

Holcombe, R., \& Lacombe, D. 2004a. The effect of state income taxation on per capita income growth. Public Finance Review, 32: 292.

Holcombe, R., \& Lacombe, D. 2004b. Using matched border counties for policy analysis: The effects of entitlement programs on female-headed households and female labor-force participation. Eastern Economic Journal, 30: 427-428.

Holland, A. S. 1984. Does higher inflation lead to more uncertain inflation?, Vol. 66: Federal Reserve Bank of St. Louis

Holmes, T. 1998. The effect of state policies on the location of manufacturing: Evidence from state borders. Journal of Political Economy, 106: 667-705.

Holtz-Eakin, D., Joulfaian, D., \& Rosen, H. S. 1994. Sticking it out: Entrepreneurial survival and liquidity constraints. Journal of Political Economy, 102: 53-75.

Holtz-Eakin, D., \& Rosen, H. 2004. Public policy and the economics of entrepreneurship. Cambridge, MA: The MIT Press.

Hornberger, S., \& Knauth, P. 1993. Interindividual differences in the subjective valuation of leisure time utility. Ergonomics, 36: 255-264.

Hox, J. 2010. Multilevel analysis: Techniques and Applications ( $2^{\text {nd }}$ ed.). New York: Routledge. 
Howard, C. 1999. The American welfare state, or states? Political Research Quarterly, 52(2): 421-442.

Huizinga, J. 1993. Inflation uncertainty, relative price uncertainty, and investment in US manufacturing. Journal of Money, Credit \& Banking 25(3).

Human, S. E., \& Matthews, C. H. 2004. Future expectations for the new business In W. B. Gartner, K. G. Shaver, N. M. Carter, \& P. Reynolds (Eds.), Handbook of entrepreneurial dynamics: The process of business creation Thousand Oaks, CA: Sage.

Hundley, G. 2000. Male/female earnings differences in self-employment: The effects of marriage, children, and the household division of labor. Industrial and Labor Relations Review, 54: 95-114.

Idson, T. L., \& Feaster, D. J. 1990. A selectivity model of employer-size wage differentials. Journal of Labor Economics, 8: 99-122.

Ilmakunnas, P., \& Kanniainen, V. 2000. Entrepreneurship, economic risks, and risk insurance in the welfare state: Results with OECD data 1978-93. German Economic Review, 2: 195-218.

Inter-University Consortium for Political and Social Research. 1991. Contiguous county file. http://www.icpsr.umich.edu/icpsrweb/ICPSR/studies/9835

Internal Revenue Service. 2010. Topic 514 - Employee business expenses. http://www.irs.gov/taxtopics/tc514.html

International Labour Organization. 2010. Laborsta. http://laborsta.ilo.org/

Irwin, D. 2003. Free trade under fire. Princeton, NJ: Princeton University Press.

Johansson, E. 2000. Self-employment and liquidity constraints: Evidence from Finland. The Scandinavian Journal of Economics 102(1): 123-134.

Johnson, J., \& Lenartowicz, T. 1998. Culture, freedom and economic growth: Do cultural values explain economic growth? Journal of World Business, 33: 332-356.

Johnson, S., McMillan, J., \& Woodruff, C. 2002. Property rights and finance. American Economic Review, 92: 1335-1356. 
Jones, T., Ram, M., \& Edwards, P. 2004. Illegal immigrants and the informal economy: worker and employer experiences in the Asian underground economy. International Journal of Economic Development, 6(2): 92-106.

Julien, P. A., Joyal, A., \& Deshaies, L. 1994. SMEs and international competition: Free trade agreement or globalization? Journal of Small Business Management, 32(3).

Karabegovic, A., McMahon, F., \& Mitchell, G. 2005. Economic freedom of North America 2005 annual report: Fraser Institute, Vancouver, BC.

Kauffman Foundation. 2011. About the Kauffman Firm Survey. http://www.kauffman.org/kfs/About-the-KFS.aspx.

Kaufman, R. S., \& Kaufman, R. T. 1987. Union effects on productivity, personnel practices, and survival in the automotive parts industry. Journal of Labor Research 8: 333-350.

Keeble, D., \& Walker, S. 1994. New firms, small firms and dead firms: spatial patterns and determinants in the United Kingdom. Regional Studies, 28: 411-427.

Keesing, D. 1983. Linking up to distant markets: South to North exports of manufactured consumer goods. The American Economic Review, 73: 338-342.

Kennan, J. 1995. The elusive effects of minimum wages. Journal of Economic Literature, 33: 1950-1965.

Kenney, M. 1986. Schumpeterian innovation and entrepreneurs in capitalism: A case study of the US biotechnology industry. Research policy, 15(1): 21-31.

Kim, T., \& Taylor, L. J. 1995. The employment effect in retail trade of California's 1988 minimum wage increase. Journal of Business and Economic Statistics, 13(2): 175-182.

Kirchhoff, B. 1994. Entrepreneurship and dynamic capitalism: The economics of business firm formation and growth. Westport, CA: Praeger.

Kirchhoff, B., Newbert, S., Hasan, I., \& Armington, C. 2007. The influence of university R\&D expenditures on new business formations and employment growth.

Entrepreneurship Theory and Practice, 31: 543-559.

Klapper, L., Laeven, L., \& Rajan, R. 2006. Entry regulation as a barrier to entrepreneurship. Journal of Financial Economics, 82: 591-629. 
Klein, P. (Ed). 2000. New institutional economics (Vol. 1). Northamption, MA: Edward Elgar.

Knowles, S., \& Weatherston, C. 2006. Informal institutions and cross-country income differences. Working paper No. 06/06. University of Nottingham, Department of Economics.

Kokkelenberg, E., \& Sockell, D. 1985. Union membership in the United States, 19731981. Industrial and Labor Relations Review, 38:497-543.

Kolvereid, L. 1996. Prediction of employment status choice intentions. Entrepreneurship: Theory and Practice, 21(1).

Kornfeld, R. 1993. The effects of union membership on wages and employee benefits: The case of Australia. Industrial and Labor Relations Review, 47: 114-128.

Kreft, S. F., \& Sobel, R. S. 2005. Public policy, entrepreneurship, and economic freedom. Cato Journal, 25: 595-616.

Krueger, A. 1974. The political economy of the rent-seeking society. The American Economic Review, 64: 291-303.

Kwoka Jr, J. 1983. Monopoly, plant, and union effects on worker wages. Industrial and Labor Relations Review: 251-257.

Lang, O., Nöhrbaß, K.-H., \& Stahl, K. 1997. On income tax avoidance: The case of Germany. Journal of Public Economics, 66: 327-347.

Langerfeld, J., \& Nieberding, J. 2005. The benefits of free trade to US consumers. Business Economics, 40(3): 41-51.

Leblang, D. 1996. Property rights, democracy and economic growth. Political Research Quarterly, 49(1): 5 .

Leonard, T. C. 2000. The very idea of applying economics: The modern minimum-wage controversy and its antecedents. History of Political Economy 32(1): 117-144.

Lindh, T., \& Ohlsson, H. 1996. Self-employment and windfall gains: Evidence from the Swedish lottery. The Economic Journal 106: 1515-1526.

Ljungqvist, L., \& Sargent, T. J. 1998. The European unemployment dilemma. Journal of Political Economy, 106: 514-550. 
Long, J. E. 1982. Income taxation and the allocation of market labor. Journal of Labor Research 3: 259-276.

Luke, D. A. 2004. Multilevel modeling. Thousand Oaks, CA: Sage.

Lumsden, K., \& Petersen, C. 1975. The effect of right-to-work laws on unionization in the United States. The Journal of Political Economy, 83: 1237-1248.

Mata, J., \& Portugal, P. 1994. Life duration of new firms. The Journal of Industrial Economics 42: 227-245.

McKinnish, T. 2007. Welfare-induced migration at state borders: New evidence from Micro-data. Journal of Public Economics, 91: 437-450.

McMullen, J. S., Bagby, D. R., \& Palich, L. E. 2008. Economic freedom and the motivation to engage in entrepreneurial action Entrepreneurship Theory and Practice, 32: 875-895.

McMullen, J. S., \& Zahra, S. A. 2006. Regulatory focus and executives' intention to commit their firms to entrepreneurial action. Paper presented at Babson College Entrepreneurship Research Conference, Babson, MA.

Mellow, W. 1981. Unionism and Wages: A Longitudinal Analysis. The Review of Economics and Statistics, 63: 43-52.

Menezes-Filho, N. 1997. Unions and profitability over the 1980s: Some evidence on union-firm bargaining in the United Kingdom. The Economic Journal: 651-670.

Miller, P., \& Mulvey, C. 1996. Unions, firm size and wages. Economic Record, 72(217): 138.

Minniti, M., Bygrave, W. D., \& Autio, E. 2005. Global entrepreneurship monitor: 2005 executive report: Babson College.

Moen, O. 2002. The born globals: A new generation of small European exporters. International Marketing Review 19(2): 156-175.

Moen, Ø., \& Servais, P. 2002. Born global or gradual global? Examining the export behavior of small and medium-sized enterprises. Journal of International Marketing 10(3): 49-72.

Moore, W. 1998. The determinants and effects of right-to-work laws: A review of the recent literature. Journal of Labor Research, 19: 445-469. 
Moore, W. J., \& Newman, R. J. 1985. The effects of right-to-work laws: A review of the literature. Industrial and Labor Relations Review, 38: 571-585.

Morissette, R. 1993. Canadian jobs and firm size: Do smaller firms pay less? Canadian Journal of Economics 26(1): 159-174.

Murphy, K., Shleifer, A., \& Vishny, R. 1993. Why is rent-seeking so costly to growth? The American Economic Review: 409-414.

Nelson, C. R. 1976. Inflation and capital budgeting. Journal of Finance 31: 923-931.

Nelson, R. 1959. The simple economics of basic scientific research. The Journal of Political Economy, 67: 297-306.

Neumark, D., \& Wascher, W. 2000. Minimum wages and employment: A case study of the fast-food industry in New Jersey and Pennsylvania: Comment. The American Economic Review, 90: 1362-1396.

Nguyen-Hong, D. 2000. Restrictions on trade in professional services. Working paper No. 1638. Government of the Commonwealth of Australia- Productivity Commission, Melbourne, Australia.

Nickell, S. 1979. Estimating the probability of leaving unemployment. Econometrica: Journal of the Econometric Society, 47: 1249-1266.

Nickell, S. 1997. Unemployment and labor market rigidities: Europe versus North America. Journal of Economic Perspectives, 11(3): 55-74.

Nickell, S. 1998. Labor market institutions and economic performance. In S. Wiemer, \& C. Lucifora (Eds.), Policies for low wage employment and social exclusion. Franco Angeli.

Noorderhaven, N., Thurik, R., Wennekers, S., \& Van Stel, A. 2004. The role of dissatisfaction and per capita income in explaining self-employment across 15 European countries. Entrepreneurship Theory \& Practice, 28: 447-467.

North, D. C. 1987. Institutions, transaction costs, and economic growth. Economic Inquiry, 25: 419-428.

North, D. C. 1990. Institutions, institutional change and economic performance. Cambridge, United Kingdom: Cambridge University Press.

Nyborg, K., \& Rege, M. 2003. On social norms: The evolution of considerate smoking behavior. Journal of Economic Behavior \& Organization, 52: 323-340. 
Nyström, K. 2008. The institutions of economic freedom and entrepreneurship: Evidence from panel data. Public Choice, 136: 269-282.

O'Connell, A., \& McCoach, D. 2007. Multilevel modeling of educational data: Information Age Pub Inc.

Oi, W. 1962. Labor as a quasi-fixed factor. The Journal of Political Economy, 70: 538555.

Ovaska, T., \& Sobel, R. 2005. Entrepreneurship in post-socialist economies. Journal of Private Enterprise, 21(1): 8-28.

Padgitt, K. M. 2009. Background paper: 2010 state business tax climate index. Washington, D.C.: Tax Foundation.

Palley, T. I., \& LaJeunesse, R. M. 2007. Social attitudes, labor law, and union organizing: Toward a new economics of union density. Journal of Economic Behavior \& Organization, 62: 237-254.

Papke, L. 1991. Interstate business tax differentials and new firm location: Evidence from panel data. Journal of Public Economics, 45(1): 47-68.

Parasuraman, A., Zeithaml, V., \& Berry, L. 1985. A conceptual model of service quality and its implications for future research. The Journal of Marketing, 49(4): 41-50.

Parker, S. C. 1996. A time series model of self-employment under uncertainty. Economica, 63: 459-475.

Parker, S., \& Robson, M. 2004. Explaining international variation in entrepreneurship: Evidence from a panel of OECD countries. Southern Economic Journal, 71: 287-301.

Partridge, M. D., \& Partridge, J. S. 1999. Do minimum wage hikes reduce employment? State-level evidence from the low-wage retail sector. Journal of Labor Research, 20: 393-413.

Pejovich, S. 1998. Economic analysis of institutions and systems. Norwell, MA: Kluwer Academic Publishers.

Peteraf, M. A. 1993. The cornerstones of competitive advantage: A resource-based view. Strategic Management Journal, 14: 179-191.

Peterson, R. 1988. Understanding and encouraging entrepreneurship internationally. Journal of Small Business Management, 26(2). 
Phillips, B. D., \& Kirchhoff, B. A. 1989. Formation, growth and survival: Small firm dynamics in the US economy. Small Business Economics, 1: 65-74.

Plummer, L. A., \& Headd, B. 2008. Rural and urban establishment births and deaths using the US Census Bureau's business information tracking series. Small Business Administration Office of Advocacy.

Porter, M. 2000. Location, competition, and economic development: Local clusters in a global economy. Economic Development Quarterly, 14(1): 15.

Poterba, J. 1995. Government intervention in the markets for education and health care: How and why? Working paper No. 4916. National Bureau of Economic Research, Cambridge, MA.

Pradhan, M., \& Van Soest, A. 1995. Formal and informal sector employment in urban areas of Bolivia. Labour Economics, 2: 275-297.

Ram, M., Edwards, P., \& Jones, T. 2007. Staying underground: Informal work, small firms, and employment regulation in the United Kingdom. Work and Occupations, 34(3): 318.

Rama, M. 2001. The consequences of doubling the minimum wage: The case of Indonesia. Industrial and Labor Relations Review: 864-881.

Rauch, J. 1991. Comparative advantage, geographic advantage and the volume of trade. The Economic Journal, 101: 1230-1244.

Raudenbush, S., \& Bryk, A. 2002. Hierarchical linear models: Applications and data analysis methods: Sage Publications.

Raudenbush, S. Bryk, A., Cheong, Y., Congdon, R., du Tolt, M. 2004. HLM 6: Hierarchical linear \& nonlinear modeling: Lincolnwood, IL: Scientific Software International.

Raudenbush, S., Bryk, A., \& Congdon, R. 2004. HLM 6 for windows. Lincolnwood, IL: Scientific Software International.

Ravetz, J. 1996. Scientific knowledge and its social problems. New Brunswick, NJ: Transaction Publishers

Rees, H., \& Shah, A. 1986. An empirical analysis of self-employment in the UK. Journal of Applied Econometrics 1(1): 95-108.

Regan, W. 1963. The service revolution. The Journal of Marketing, 27(3): 57-62. 
Reynolds, P. 2004. Overview: Life context, personal background. In W. B. Gartner, K. G. Shaver, N. M. Carter, \& P. Reynolds (Eds.), Handbook of entreprenerial dynamics: The process of business creation Thousand Oaks, CA: Sage.

Reynolds, P., Bosma, N., Autio, E., Hunt, S., De Bono, N., Servais, I., Lopez-Garcia, P., \& Chin, N. 2005. Global entrepreneurship monitor: Data collection design and implementation 1998-2003. Small Business Economics, 24: 205-231.

Reynolds, P. D., Bygrave, W. D., Autio, E., Cox, L. W., \& Hay, M. 2004. Global Entrepreneurship Monitor 2003 executive report: Kansas City.

Rich, R., \& Tracy, J. 2004. Uncertainty and labor contract durations. Review of Economics and Statistics, 86: 270-287.

Roberts, J. 2007. Group dependency in the presence of small intraclass coefficients: An argument in favor of not interpreting the ICC. Paper presented at the annual meeting of the American Educational Research Association, Chicago, IL.

Robson, M. T., \& Wren, C. 1999. Marginal and Average Tax Rates and the Incentive for Self-Employment. Southern Economic Journal, 65: 757-758.

Rodrik, D., Subramanian, A., \& Trebbi, F. 2004. Institutions rule: The primacy of institutions over geography and integration in economic development. Journal of Economic Growth, 9(2): 131-165.

Romer, D. 1996. Advanced Macroeconomics. New York: McGraw-Hill.

Romer, P. M. 1994. The origins of endogenous growth. The Journal of Economic Perspectives, 8(1): 3-22.

Sachs, J., \& Warner, A. 2001. The curse of natural resources. European Economic Review, 45: 827-838.

Salvatore, D. 2003. The new economy and growth in the G-7 countries. Journal of Policy Modeling, 25: 531-540.

Sauka, A., \& Welter, F. 2007. Productive, productive and destructive entrepreneurship in an advanced transition setting: The example of Latvian small enterprises. In M. Dowling, \& S. Jurgen (Eds.), Empirical entrepreneurship in Europe: New perspectives: 87. Northamption, MA: Edward Elgar Publishing.

Schmitt, J., Rho, H. J., \& Fremstad, S. 2009. US unemployment now as high as Europe, CEPR reports and issue briefs. Washington, D.C.: Center for Economic and Policy Research. 
Schnepf, R., \& Womach, J. 2008. Potential challenges to US farm subsidies in the WTO. New York: Nova Science Publishers.

Schuetze, H. 2000. Taxes, economic conditions and recent trends in male selfemployment: A Canada-US comparison. Labour Economics, 7: 507-544.

Schuetze, H. 2002. Profiles of tax non-compliance among the self-employed in Canada: 1969 to 1992. Canadian Public Policy/Analyse de Politiques, 28: 219-238.

Schumpeter, J. A. 1942. Capitalism, Socialism, and Democracy. New York: Harper \& Brothers

Scully, G. 1991. Rent-seeking in US government budgets, 1900-88. Public Choice, 70: 99-106.

Shane, S. 1993. Cultural influences on national rates of innovation. Journal of Business Venturing, 8: 59-73.

Shane, S. 2003. A general theory of entrepreneurship: The individual-opportunity nexus. Northhampton, MA: Edward Elgar.

Shane, S., \& Venkataraman, S. 2000. The Promise of Entrepreneurship as a Field of Research Academy of Management Review 25: 217-226.

Short, J., Ketchen Jr, D., Bennett, N., \& du Toit, M. 2006. An examination of firm, industry, and time effects on performance using random coefficients modeling. Organizational Research Methods, 9: 259.

Siebert, H. 1997. Labor market rigidities: At the root of unemployment in Europe. Journal of Economic Perspectives, 11(3): 37-54.

Singh, G. 2001. National culture and union density. Journal of Industrial Relations, 43: 330 .

Sinn, H. 1995. A theory of the welfare state. The Scandinavian Journal of Economics, 97: 495-526.

Sinn, H. 1996. Social insurance, incentives and risk taking. International Tax and Public Finance, 3: 259-280.

Smith, A. 1976 [1776]. An inquiry into the causes of the the wealth of nations. Chicago: University of Chicago Press. 
Sobel, R. S. 2008. Testing Baumol: Institutional quality and the productivity of entrepreneurship. Journal of Business Venturing, 23: 641-655.

Sobel, R. S., Clark, J. R., \& Lee, D. R. 2007. Freedom, barriers to entry, entrepreneurship, and economic progress. The Review of Austrian Economics, 20: $221-236$.

Solow, R. M. 1957. Technical Change and the Aggregate Production Function The Review of Economics and Statistics 39: 312-320.

Stansel, D., Gohmann, S., \& Hobbs, B. 2008. Local government finance and entrepreneurial activity in U.S. metropolitan areas. SSRN working paper series.

Stevens, P. 2003. Resource Impact-Curse or Blessing? Investment Policy, 22.

Stewart, M. 1990. Union wage differentials, product market influences and the division of rents. The Economic Journal, 100: 1122-1137.

Stigler, G. 1971. The theory of economic regulation. The Bell Journal of Economics and Management Science: 2(1): 3-21.

Stigler, G. J. 1946. The economics of minimum wage legislation. The American Economic Review, 36: 358-365.

Stinchcombe, A. L. 1965. Social structure and organizations. In J. March (Ed), Handbook of organizations: $142-193$. Chicago: Rand McNally.

Tabachnick, B. G., \& Fidell, L. S. 2006. Using multivariate statistics (5th ed.). Boston: Allyn \& Bacon.

Tervo, H. 2006. Regional unemployment, self-employment and family background. Applied Economics, 38: 1055-1062.

The World Bank. 2010. Data: Indicators. http://data.worldbank.org/indicator

Thelen, K. 2004. How institution evolve: The political economy of skills in Germany, Britain, the United States, and Japan. New York: Cambridge University Press.

Thurik, R., \& Wennekers, S. 2004. Entrepreneurship, small business and economic growth. Journal of Small Business and Enterprise Development, 11(1): 140149.

Tollison, R. 1982. Rent seeking: A survey. Kyklos, 35: 575-602. 
Torrini, R. 2005. Cross-country differences in self-employment rates: The role of institutions. Labour Economics, 12: 661-683.

Torstensson, J. 1994. Property rights and economic growth: an empirical study. Kyklos, 47(2): 231.

Tsang, E. W., \& Kwan, K. 1999. Replication and theory development in organizational science: A critical realist perspective. Academy of Management Review: 24(4): 759-780.

Ucbasaran, D., Westhead, P., \& Wright, M. 2008. Opportunity identification and pursuit: does an entrepreneur's human capital matter? Small Business Economics, 30: 153-173.

U.S. Census Bureau. 2009a. About counties: San Bernardino California. http://quickfacts.census.gov/qfd/states/06/06071.html

U.S. Census Bureau. 2009b. Federal, state, and local governments. http://www.census.gov/govs/www/

U.S. Census Bureau. 2009c. State \& county quickfacts: Maryland. http://quickfacts.census.gov/qfd/states/24000.html

U.S. Census Bureau. 2011a. Small area income and poverty estimates. http://www.census.gov/did/www/saipe/data/statecounty/data/index.html.

U.S. Census Bureau. 2011 b. Population estimates. http://www.census.gov/popest/counties/counties.html.

U.S. Constitution. Art. 1, sec. 10

U.S. Constitution. Art. 1, amend. X.

United States Department of Labor. 2009. Minimum wage laws in the states. http://www.dol.gov/whd/minwage/america.htm

U.S. Department of Labor- Wage and Hour Division . 2010. State right-to-work laws and constitutional amendments in effect as of January 1, 2009 with year of passage. http://quickfacts.census.gov/qfd/states/24000.html

Van Praag, C., \& Versloot, P. 2007. What is the value of entrepreneurship? A review of recent research. Small Business Economics, 29: 351-382. 
van Stel, A., Storey, D. J., \& Thurik, R. A. 2007. The effect of business regulations on nascent and young business entrepreneurship Small Business Economics 28: 171-186.

Van Stel, A., \& Suddle, K. 2008. The impact of new firm formation on regional development in the Netherlands. Small Business Economics, 30: 31-47.

Vesper, K. 1982. Introduction and summary of entrepreneurship research. Encyclopaedia of Entrepreneurship, Prentice-Hall, Englewood Cliffs, NJ, pp. xxi.

Voos, P. B., \& Mishel, L. R. 1986. The union impact on profits in the supermarket industry. The Review of Economics and Statistics, 68: 513-517.

Wager, T. H. 1998. Determinants of human resource management practices in small firms: Some evidence from Atlantic. Journal of Small Business Management, 36(2): 13-23.

Waltman, J., McBride, A., \& Camhout, N. 1998. Minimum Wage Increases and the Business Failure Rate. Journal of Economic Issues, 32(1).

Wasylenko, M. 1980. Evidence of fiscal differentials and intrametropolitan firm relocation. Land Economics, 56: 339-349.

Wennekers, S., van Stel, A., Thurik, R. A., \& Reynolds, P. 2005. Nascent entrepreneurship and the level of economic development. Small Business Economics, 24(3).

Wessels, W. 2007. A Reexamination of Card and Krueger's State-Level Study of the Minimum Wage. Journal of Labor Research, 28: 135-146.

Wessels, W. J. 1981. Economic effects of right to work laws. The Journal of Political Economy, 2: 55-75.

Williamson, O. E. 2000. The new institutional economics: Taking stock, looking ahead. Journal of Economic Literature, 38: 595-613.

Wilner, A., Olshan, J. 2008. NJ bakers' fat chance eye trans-ban bonanza. New York Post.

Winter-Ebmer, R. 2001. Firm size, earnings, and displacement risk. Economic Inquiry, 39: 474-486.

Wolff, E. N. 1998. Recent trends in the size distribution of household wealth. The Journal of Economic Perspectives, 12(3): 131-150. 
Wong, P. K., Ho, Y. P., \& Autio, E. 2005. Entrepreneurship, innovation and economic growth: Evidence from GEM data. Small Business Economics, 24: 335-350.

Wooldridge, J. M. 2003. Introductory Econometrics. Mason, Ohio: Thomson SouthWestern.

World Trade Organization. 2009. What is the World Trade Organization? http://www.wto.org/english/thewto_e/whatis_e/whatis_e.htm

Zavodny, M. 1998. Why Minimum Wage Hikes May Not Reduce Employment. Federal Reserve Bank of Atlanta Economic Review.

Zucker, L., Darby, M., \& Brewer, M. 1998. Intellectual human capital and the birth of US biotechnology industry. American Economic Review, 88: 290-306. 


\section{CURRICULUM VITAE}

\begin{tabular}{c} 
Michael D. Crum \\
\hline 2784 Cedarville Drive Apt. 1 \\
Marquette, MI 49855 \\
mcrum@nmu.edu 812-989-1875 \\
Employment History
\end{tabular}

Northern Michigan University Instructor, Entrepreneurship

August 2010 to present

University of Louisville

Teaching \& Research Assistant

August 2006 to July 2010

\section{Educational Background}

University of Louisville

Ph.D. in Entrepreneurship, December 2011

Indiana University Southeast

MBA, June 2006

MS in Strategic Finance, June 2006

BS in Accounting and Finance, May 2004

Publications

Raju, P., Lonial, S., \& Crum, M. Market Orientation in SMEs: A Conceptual Framework. In Press, Journal of Business Research.

Conference Presentations

Crum, M., Nelson, T. Entrepreneurs and Institutions: Three Institutional Factors and their Effects. Presented at the United States Association for Small Business and Entrepreneurship, 2011. Hilton Head, South Carolina. 
Gohmann, S., Pinkerton, J., Crum, M. The Location Decision of Entrepreneurs in MultiState Metropolitan Areas. Presented at the Babson College Entrepreneurship Research Conference, 2010. Lausanne, Switzerland.

Crum, M. Labor Market Institutions, New Firm Attributes and New Firm Employment Growth. Presented at the Association of Private Enterprise Education Conference, 2010. Las Vegas, Nevada.

Crum, M., Gohmann, S. The Influence of Governmental Institutions on the Likelihood of an Individual Becoming an Entrepreneur. Presentation at the Babson College Entrepreneurship Research Conference, 2009. Babson Park, Massachusetts.

Crum, M., Mitteness, C. Extremism and Social Identity: An Explanation for Informal User Innovation. Presentation at the Academy of Management Conference, 2008. Anaheim, California.

Crum, M., Meek, W. Legitimacy, Innovation, and Industry Emergence: The Case of the Light Sport Aircraft Industry. Presentation at the Academy of Management Conference, 2008. Anaheim, California.

Gohmann, S., Crum, M. Technology Transfer Office Incentives and Performance. Presentation at the Babson College Entrepreneurship Research Conference, 2008. Chapel Hill, North Carolina.

Awards

Student nominated as a "Faculty Favorite" for contribution to student growth and learning. October 2009, University of Louisville.

Entrepreneurship Division Doctoral Consortium at the Academy of Management Conference, Chicago IL. August 2009.

Awarded Kauffman Foundation funded seat on the NORC Data Enclave to access confidential Kauffman Firm Survey data. June 2009. 